\title{
The effect of grassland botanical composition and (co-) grazing cattle and sheep on herbage production and sward nutrient utilisation
}

\author{
Dissertation \\ Zur Erlangung des Doktorgrades \\ der Fakultät für Agrarwissenschaften \\ der Georg-August-Universität Göttingen
}

vorgelegt von

Melanie Seither

geboren in Landau in der Pfalz

Göttingen, Mai 2011 
D 7

1. Gutachter: Prof. Dr. Johannes Isselstein

2. Gutachter: Prof. Dr. Klaus Dittert

Tag der mündlichen Prüfung: 11.07.2011 


\section{Contents}

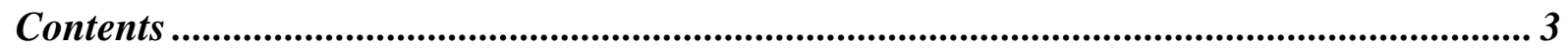

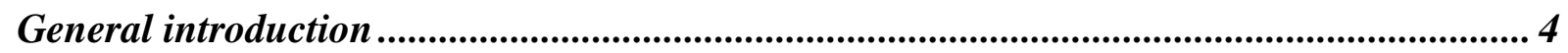

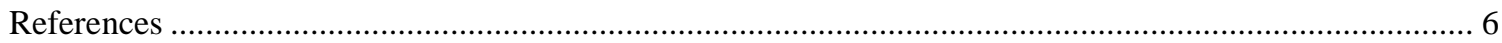

Initial mono- and co-grazing effects of cattle and sheep on vegetation development of

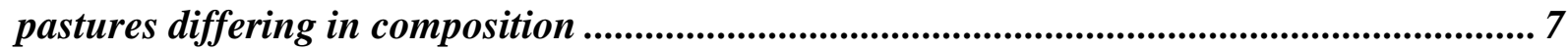

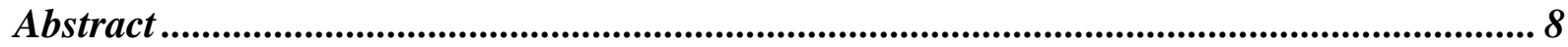

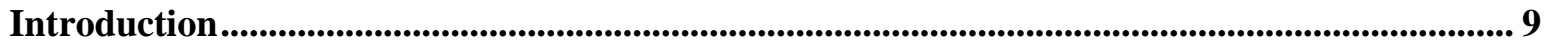

Material and Methods ............................................................................................................................... 12

Discussion........................................................................................................................................................... 22

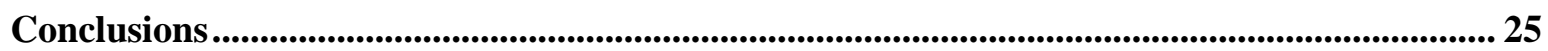

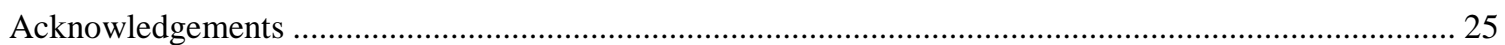

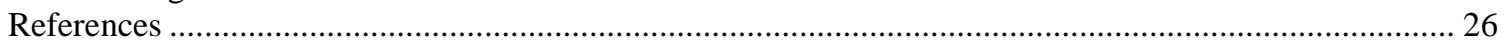

Effects of sward composition and co-grazing on production and quality of herbage .......... 29

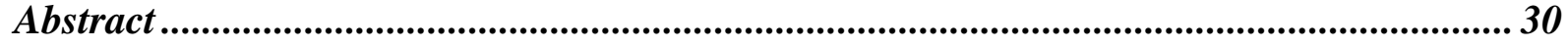

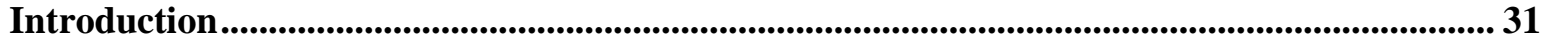

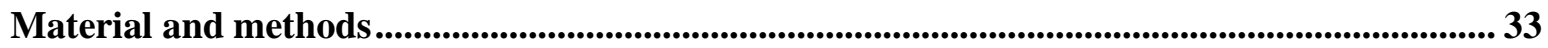

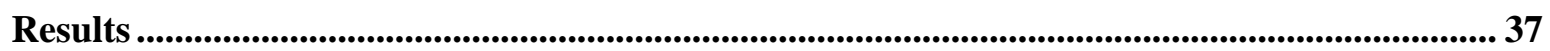

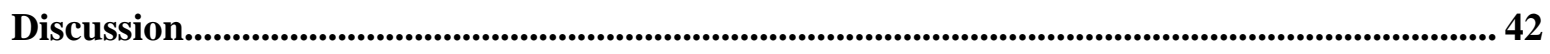

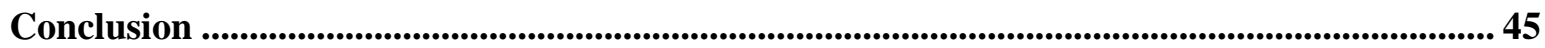

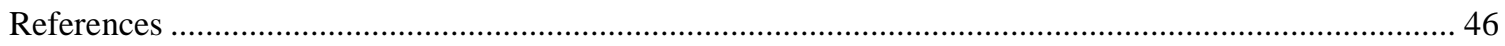

Productivity and nutrient use in grassland of differing plant species composition and

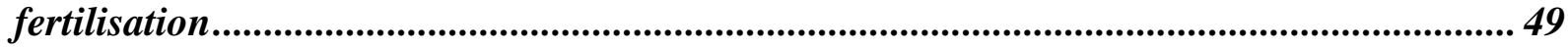

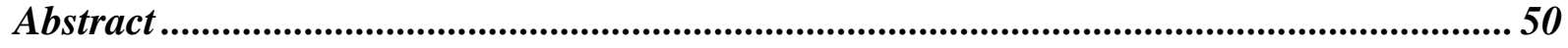

Introduction .................................................................................................................................................... 51

Material and Methods ........................................................................................................................... 53

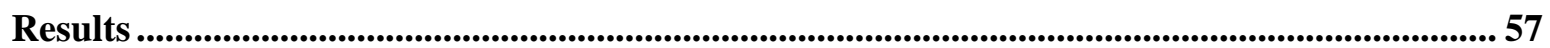

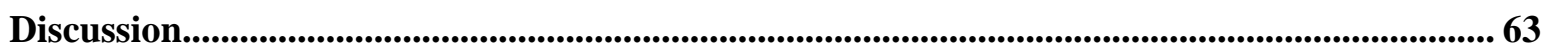

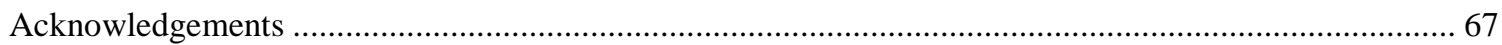

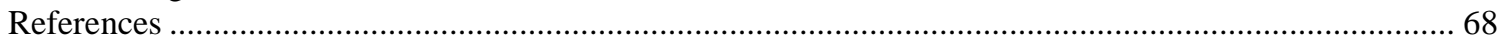

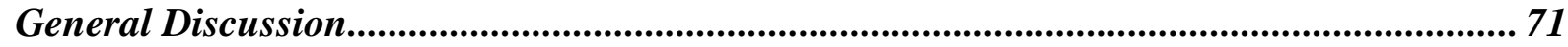

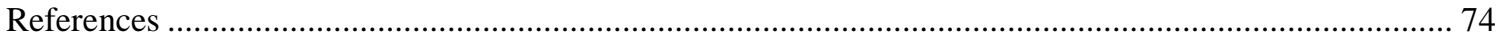

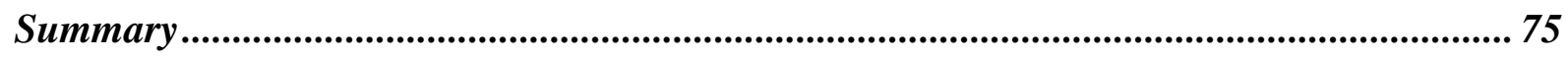

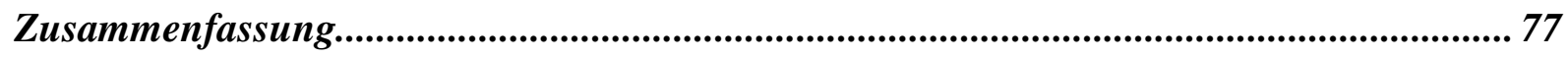

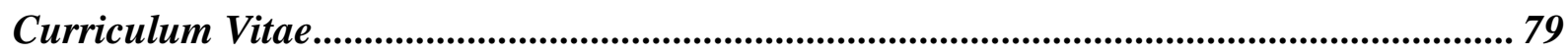

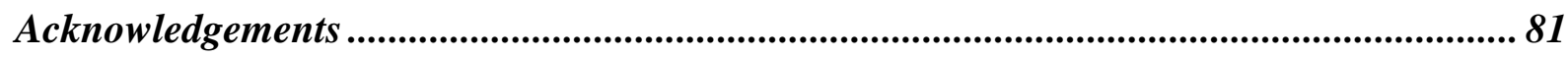




\section{General introduction}

Intensification of agriculture is the major reason for worldwide biodiversity loss (Tscharntke et al., 2005). Permanent grasslands, accounting for approximately $8 \%$ of the land surface in Europe (FAO, 2008), make an important contribution to plant diversity (Nösberger and Rodríguez, 1996). Diverse systems have a great potential in increasing the supply with and the sustainability of ecosystem services and might be advantageous compared to simplified or less species-rich communities under the conditions of climate change: The productivity (Tilman et al., 2001) and stability of biomass production (Richardson et al., 2010) can be increased by plant diversity.

Different reasons for the diversity-functioning relationship have been discussed, e.g. the number of plant species with differing traits (Hooper and Dukes, 2004), the 'functional identity' of the dominant species (Mokany et al., 2008), complementarity of resource use (Spehn et al., 2005) and the possibility of complementary interactions determined by spatial dimension (Dimitrakopoulos and Schmid, 2004). The presence of $\mathrm{N}$ fixing legumes and arbuscular mycorrhizal fungi (AMF) can also contribute to larger productivity, due to their positive effects on N supply (Spehn et al., 2002) and P acquisition of plants (Jakobsen et al., 1992). There are hints to a specifity between AMF and plant species (Vandenkoornhuyse et al., 2003) and differences in functioning of AMF species (Helgason et al., 2002). Therefore, different vegetation composition might be related to differences in AMF functioning.

Grazing is a common type of grassland management adequate for the maintenance and recreation of diverse grasslands (Collins et al., 1998). Grazing can affect sward heterogeneity and thereby may affect plant diversity (Adler et al., 2001). Grazing animals alter the sward by their feeding choices, nutrient return and treading. Grazer species differ in their herbage quality requirements, smaller grazer species have a demand for higher quality herbage than larger grazers and thus are more selective (Rook et al., 2004). Therefore, co-grazing of animal species may result in complementary grazing, leading to a more efficient sward utilisation and a different vegetation development than mono-grazing. The amount and pattern of nutrient return by animal excretion may affect the nutrient use and vegetation composition either directly or indirectly via changes in belowground processes, e.g. the functioning of legumes' rhizobia and AMF.

So far, few studies on the diversity-functionality relationship have been conducted in grassland with a long history of agricultural use. Differences in sward composition and herbage quality and quantity likely affect the grazing animals' feeding decisions and performance. This in turn should have an impact on the sward structure and development. 
There is little knowledge on the interaction between sward composition and animal behaviour on vegetation development, herbage productivity, quality and nutrient use in semi-natural grasslands.

Therefore, our objectives were to

1) Analyse the effects of mono- and co-grazing cattle and sheep on the vegetation development and sward use in a semi-natural moderately diverse sward and its grassdominated counterpart (Chapter I);

2) Determine sward and grazing animal effects on herbage quality and productivity (Chapter II);

3) Evaluate the impact of sward composition and nitrogen or phosphorus input, simulating animal urine and faeces, on nutrient use and productivity affected by the functioning of legumes and AMF (Chapter III); 


\section{References}

Adler, P., D. Raff, and W. Lauenroth. 2001. The effect of grazing on the spatial heterogeneity of vegetation. Oecologia 128:465-479.

Collins, S.L., A.K. Knapp, J.M. Briggs, J.M. Blair, and E.M. Steinauer. 1998. Modulation of diversity by grazing and mowing in native tallgrass prairie. Science 280:745-747.

Dimitrakopoulos, P.G., and B. Schmid. 2004. Biodiversity effects increase linearly with biotope space. Ecology Letters 7:574-583.

FAO. 2008. Food and agriculture organization of the united nations. FAOSTAT Online Statistical Service, Rome: FAO.

Helgason, T., J.W. Merryweather, J. Denison, P. Wilson, J.P.W. Young, and A.H. Fitter. 2002. Selectivity and functional diversity in arbuscular mycorrhizas of co-occurring fungi and plants from a temperate deciduous woodland. Journal of Ecology 90:371-384.

Hooper, D.U., and J.S. Dukes. 2004. Overyielding among plant functional groups in a long-term experiment. Ecology Letters 7:95-105.

Jakobsen, I., L.K. Abbott, and A.D. Robson. 1992. External hyphae of vesicular-arbuscular mycorrhizal fungi associated with Trifolium subterraneum L. 1. Spread of hyphae and phosphorus inflow into roots. New Phytologist 120:371-380.

Mokany, K., J. Ash, and S. Roxburgh. 2008. Functional identity is more important than diversity in influencing ecosystem processes in a temperate native grassland. Journal of Ecology 96:884893.

Nösberger, J., and M. Rodríguez. 1996. Increasing biodiversity through management. Grass and Forage Science 1:949-956.

Richardson, P.J., J. Horrocks, and D.W. Larson. 2010. Drought resistance increases with species richness in restored populations and communities. Basic and Applied Ecology 11:204-215.

Rook, A.J., B. Dumont, J. Isselstein, K. Osoro, M.F. WallisDeVries, G. Parente, and J. Mills. 2004. Matching type of livestock to desired biodiversity outcomes in pastures - a review. Biological Conservation 119:137-150.

Spehn, E.M., M. Scherer-Lorenzen, B. Schmid, A. Hector, M.C. Caldeira, P.G. Dimitrakopoulos, J.A. Finn, A. Jumpponen, G. O'Donnovan, J.S. Pereira, E.-D. Schulze, A.Y. Troumbis, and C. Körner. 2002. The role of legumes as a component of biodiversity in a cross-European study of grassland biomass nitrogen. Oikos 98:205-218.

Spehn, E.M., A. Hector, J. Joshi, M. Scherer-Lorenzen, B. Schmid, E. Bazeley-White, C. Beierkuhnlein, M.C. Caldeira, M. Diemer, P.G. Dimitrakopoulos, J.A. Finn, H. Freitas, P.S. Giller, J. Good, R. Harris, P. Högberg, K. Huss-Danell, A. Jumpponen, J. Koricheva, P.W. Leadley, M. Loreau, A. Minns, C.P.H. Mulder, G. O'Donovan, S.J. Otway, C. Palmborg, J.S. Pereira, A.B. Pfisterer, A. Prinz, D.J. Read, E.-D. Schulze, A.-S.D. Siamantziouras, A.C. Terry, A.Y. Troumbis, F.I. Woodward, S. Yachi, and J.H. Lawton. 2005. Ecosystem effects of biodiversity manipulations in European grasslands. Ecological Monographs 75:37-63.

Tilman, D., P.B. Reich, J. Knops, D. Wedin, T. Mielke, and C. Lehman. 2001. Diversity and productivity in a long-term grassland experiment. Science 294:843-845.

Tscharntke, T., A.M. Klein, A. Kruess, I. Steffan-Dewenter, and C. Thies. 2005. Landscape perspectives on agricultural intensification and biodiversity - ecosystem service management. Ecology Letters 8:857-874.

Vandenkoornhuyse, P., K.P. Ridgway, I.J. Watson, A.H. Fitter, and J.P.W. Young. 2003. Co-existing grass species have distinctive arbuscular mycorrhizal communities. Molecular Ecology 12:3085-3095. 


\section{Chapter I:}

Initial mono- and co-grazing effects of cattle and sheep on vegetation development of pastures differing in composition

Seither M., Petersen U., Wrage N., Isselstein J. 


\begin{abstract}
Grassland plant diversity is influenced by site conditions and agricultural management. In this study, we investigated the initial effect of grazing cattle and sheep alone or together (cograzing) on vegetation composition, diversity and sward structure of an extensively managed semi-natural grassland sward with initially different diversity, established by herbicide application. The experimental sites were a moderately species-rich Lolio-Cynosuretum in the Solling Uplands (Germany) and its grass-dominated counterpart. The six combinations of plant diversity and grazing treatment were replicated three times in blocks grazed rotationally. Mono-grazing cattle led to significant changes in vegetation composition compared to sheepand co-grazing after two years of differential grazing. The vegetation composition of cograzed paddocks was intermediate between cattle- and sheep-grazed paddocks in the diverse and grass swards. There were no hints to complementary foraging effects caused by cograzing cattle and sheep on sward structure. We found hints to larger forage selectivity by sheep affecting the vegetation composition. Grazing animal and sward type had a significant impact on post-grazing sward structure. This suggests that grazing animals adopt different foraging strategies in response to the sward composition.
\end{abstract}

Key words: grassland; monocots; dicots; foraging behaviour; rotational grazing; sward height 


\section{Introduction}

European grassland makes an important contribution to biodiversity in agricultural landscapes (Nösberger and Rodriguez, 1996). Site specific factors such as soil type, nutrients, climate and management practices affect grassland diversity and composition (Isselstein et al., 2005).

The maintenance of diverse grassland in Europe depends on management measures like mowing or pasturing to avoid a progress in succession and a change in the typical vegetation composition. Grazing promotes vegetation dynamics and (re-) establishment of plant species more than other management practices (Kahmen et al., 2002) and is, therefore, considered an effective means for conservation and maintenance of diverse grassland (Hayes and Holl, 2003; Loucougaray et al., 2003; Rogalski and Pawska-Olejniczak, 2010). It results in a heterogeneous sward structure due to the grazing animal's specific foraging behaviour (Rook et al., 2004), treading (Rook and Tallowin, 2003) and nutrient return by dung and urine (Rook et al., 2004). Selective foraging exerts a local control on competitive plant species enabling subordinate species to coexist (Grime and Mackey, 2002). Small-scale soil disturbance by treading can create niches for gap-colonising species (Hofmann and Isselstein, 2004). Both mechanisms are seen as crucial for the promotion of grassland diversity (Loucougaray et al., 2003). The pattern of nutrient input via excretion of faeces affects the vegetation by a change in local resource conditions (Rook et al., 2004), which in turn influences the competitive relationship of plants. Both, selective foraging and excretion patterns affect vegetation composition via their effects on plant responses and belowground organisms (Bardgett et al., 1998; Ribas et al., 2010).

The selective grazing behaviour of herbivores is species-specific and to a great extent determined by the body size of the grazing animal. Large grazers like cattle have a slower throughput and more efficient digestion than small grazers like sheep and can, therefore, better cope with low forage quality (Rook et al., 2004). Small grazers, however, are in need of high quality forage and are consequently more selective. Due to the small size of their jaws, they are usually able to pick only certain parts of a plant, where larger animals have to take the whole plant.

Cattle grazing has been found to facilitate both diversity and abundance of annual forbs compared to ungrazed sites (Hayes and Holl, 2003). Grazing with sheep may lead to an increase in grasses (Sebastià et al., 2008) while the proportion of forbs and legumes may decrease (de Bello et al., 2005; Nolan et al., 2001) due to a higher selectivity of sheep for the latter. Mixed grazing can increase the utilisation of excreta patches of the respective other species, as found in pastures co-grazed by cattle and sheep or horses (Forbes and Hodgson, 
1985; Loucougaray et al., 2003). Sheep and cattle also affect the sward structure differently; cattle create more patchy swards than sheep (Nolan et al., 2001), probably attributable to larger, less homogeneously distributed excreta patches. Due to grazer species specific effects on sward structure, the choice of the grazing animal species might be a means to achieve desirable plant species composition and biodiversity (Stewart and Pullin, 2006) by facilitating a dynamic spatial heterogeneity of pastures (Rook et al., 2004). However, grazing might also decrease the heterogeneity in vegetation composition caused by environmental factors (Fuhlendorf and Smeins, 1998) and different grazing animal species do not seem to favour vegetation heterogeneity equally: Sebastià (2008) found cattle to increase the heterogeneity of the vegetation, both on the patch and landscape scale, while sheep increased homogeneity and facilitated the presence of species with conservation value. The combination of both cattle and sheep might be advantageous for controlling plant species differing in toxicity for the two grazing animal species (Hejcman et al., 2008) and might increase the grazing effect on grassland diversity and composition (Loucougaray et al., 2004). Co-grazing could be beneficial for an optimal use of the pasture by complementary foraging behaviour, as found for cattle co-grazing with horses (Loucougaray et al., 2003) or goats (Webb et al.), the latter being the effect of goats feeding on woody plants avoided by cattle. However, tall swards support a higher diversity and abundance of grassland animals like arachnids and arthropods, whereas some species are bound to low sward heights (Dennis et al., 2001; Morris, 2000). Therefore, a heterogeneous sward structure might be best for the preservation of grassland animal diversity and abundance.

So far, studies on grazing animals have often investigated the effects of either animals grazing alone, together (Abaye et al., 1994; Nolan and Connolly, 1989) or sequentially (Fraser et al., 2007) on animal performance. When the impact on plant species composition and diversity was explored, studies mainly focused on cattle grazing alone (Pykälä, 2004) or together, e.g. with horses (Loucougaray et al., 2004). Sheep effects on vegetation grazing alone (Sebastià et al., 2008), together with small herbivores (Denyer et al., 2010), goats (Animut et al., 2005) or in comparison with other mono-grazing herbivores like cattle were addressed (Reyneri et al., 1994). However, there is little knowledge on the effect of sheep mono- and co-grazing with cattle on vegetation development and composition of complex swards (Stewart and Pullin, 2006). Therefore, we carried out a study on grassland swards with initially differing vegetation composition grazed by sheep and cattle alone or in combination. We addressed the following question: Does grazing with cattle and sheep alone or together change the differences in vegetation composition of a diverse or grass-dominated sward within three 
years after a change in management? We hypothesised that (1) pastures grazed by cattle or sheep alone show differences in vegetation development, (2) the utilisation of the co-grazed sward is larger, resulting in a more homogeneous vegetation composition, 3) the grazers adapt their foraging behaviour in response to sward composition, resulting in a different vegetation development in grass compared to diverse swards. 


\section{Material and Methods}

The experimental site, an area of 9 ha in total, is moderately species rich and can be assigned to the plant-association Lolio-Cynosuretum. It is located in the Solling Uplands, Germany $\left(51^{\circ} 46^{\prime} 47 \mathrm{~N}, 9^{\circ} 42^{\prime} 11 \mathrm{E}\right.$; the altitude of the total area ranges from 184 to $209 \mathrm{~m}$ above sea level). The site had been managed as a mown pasture with varying proportions of cattle and sheep for more than 16 years before the start of the experiment. Light manure was applied regularly to the total area; however, not all parts of the site were completely accessible for mowing or application of manure. The soil type is a pelosol, the texture is clayey/silty loam. The average annual precipitation is $879 \mathrm{~mm}$ and the average temperature $8.2^{\circ} \mathrm{C}(1961-1990$, Deutscher Wetterdienst, DWD, Location: Dassel - $3 \mathrm{~km}$ from the experimental site). To characterise initial soil conditions, composite soil samples (consisting of eight subsamples) were taken around five randomly distributed permanent plots per paddock (also used for vegetation relevés) to a depth of $10 \mathrm{~cm}$ (P, K, Mg; July 2007) and $30 \mathrm{~cm}$ (mineral N analysis; October 2007; soil corers were 1.7 and $1.8 \mathrm{~cm}$ in diameter, respectively). The $\mathrm{pH}$ of the soil (in $\mathrm{CaCl}_{2}$ suspension) as well as the availability of $\mathrm{P}, \mathrm{K}$ (extracted with calcium acetate lactate, continuous flow analyser [CFA]), $\mathrm{Mg}\left(\mathrm{CaCl}_{2}\right.$ extraction, $\left.\mathrm{CFA}\right)$ and mineral $\mathrm{N}(\mathrm{KCl}$ extraction, CFA) showed the large variability typical for pastures $\left(\mathrm{pH}: 6.8 \pm 0.3\right.$; in $\mathrm{mg} 100 \mathrm{~g}^{-}$ ${ }^{1}$ dry matter: P: $7.9 \pm 3.2, \mathrm{~K}: 17.4 \pm 4.9, \mathrm{Mg}: 35.8 \pm 8.4, \mathrm{NO}_{3}{ }^{-}: 0.5 \pm 0.1, \mathrm{NH}_{4}{ }^{+}: 0.2 \pm 0.01$, means \pm standard deviation, sd).

In this experiment, two factors were manipulated, namely the botanical diversity and the species of grazer. The initial diversity of the sward was manipulated in summer 2006, prior to the start of the experiment, by the use of a herbicide against dicotyledonous plants (active components Fluroxypyr/ Triclopyr) resulting in a low diversity grass-dominated sward ('grass sward') compared to the untreated 'diverse sward' (referred to as 'sward types' in the following). The number of plant species after the herbicide application (based on five $9 \mathrm{~m}^{2}$ relevés per paddock) was $9.2 \pm 2.5$ and $13.8 \pm 3.7$ (mean \pm sd) in 2007 for the grass and diverse sward, respectively.

Both diversity treatments were either grazed by sheep, by cattle or by both starting in May 2007. Grazing cattle were suckler cows and calves of the breed German Simmental. Ewes with lambs were Blackheaded and Leine sheep in comparable proportions. Animals were assigned to 0.5 ha paddocks on a live weight basis. For co-grazed paddocks, sheep and cattle were used in equal weight proportions. All treatments were replicated three times in blocks that were rotationally grazed three times per year (2 sward types x 3 grazing treatments $\mathrm{x} 3$ 
blocks: 18 paddocks); data of three years, from 2007 to 2009, were collected. The grazing pressure was $13.7 \pm 1.4$ and $14.3 \pm 1.6 \mathrm{LU} \mathrm{ha}^{-1}(\mathrm{LU}=$ livestock unit of $500 \mathrm{~kg}$ ) in grazing cycles one and two; in the third cycle grazing pressure was reduced to $8.6 \pm 0.6 \mathrm{LU} \mathrm{ha}^{-1}$ (mean $\pm \mathrm{sd}$ ) to adapt to slower vegetation growth. The grazing period typically lasted from beginning of May to mid-September with a break of approximately six weeks for animal mating after the second grazing cycle. The grazing time in each rotation cycle depended on the herbage on offer; due to the grazing break and reduced grazing pressure in the third cycle, grazing time was similar to the first cycle: $11 \pm 3.1$ and $12.3 \pm 1.4$ for first and third cycles vs. $6.1 \pm 2.8$ days (mean \pm sd of the three years) for the second cycle.

Five permanent points per paddock were established for vegetation analysis and soil sampling following the generation of randomly distributed points with the program Hawth's Analysis Tool for ArcGIS 9.1. Vegetation composition was monitored in May/June from 2007 to 2009 by means of vegetation relevés of $1 \mathrm{~m}^{2}$ and $9 \mathrm{~m}^{2}$ surrounding the permanent points. In the 1 $\mathrm{m}^{2}$ relevés, species number, composition and yield estimates (Klapp and Stählin, 1936) were recorded. For the baseline data of 2007, the yield estimates were performed on functional group level (grasses, herbs, legumes), in 2008 and 2009 on plant species level. In the $9 \mathrm{~m}^{2}$ relevés, additionally occurring plant species were recorded. The plant species Agrostis gigantea and Agrostis stolonifera were hard to differentiate; observations were, therefore, combined to the species consortium 'Agrostis spec.'. Sward height measurements were carried out to provide insights of how grazing animals affect the sward structure. To this end, fifty measurements of compressed sward height were taken in a zigzag transect across the paddock before and after each grazing event with a rising plate meter (Castle, 1976). To compare sward structure and sward utilisation between treatments, coefficient of variation of post-grazing sward height $(\mathrm{CV}=\mathrm{sd} /$ mean sward height $)$ and post-grazing sward heights were analysed. Values on the nutritional value of plant species were gained from the BiolFlor database (Klotz et al., 2002a).

The experiment was set up as a two-factorial block design with the fixed factors sward type and grazing system and the random factor block. Vegetation data was analysed using multivariate ordination techniques in Canoco (ter Braak and Smilauer, 1997-2004). Detrended correspondence analysis (DCA) resulted in gradient lengths (length of the first DCA axis) smaller than three, therefore, we used linear methods for further analysis (Leyer and Wesche, 2008). To calculate the different impact of our treatments versus the environmental/spatial influences on vegetation composition, we conducted the variance partitioning procedure using partial redundancy analysis (Vandvik and Birks, 2002). For this procedure, two groups of 
environmental variables were built, one including treatment factors (sward diversity and grazing treatments) and the other spatial factors (slope, North- and East-orientation of the plots, block (Borcard and Legendre, 1994)). Plant species abundances were log-transformed apart from that the default setting of CANOCO was used. A split-plot design was used to account for the sampling design of five sub-plots in each 'whole plot'; Monte Carlo tests with 199 permutations were performed at the whole plot- but not on the split-plot-level. As spatial factors accounted for a larger proportion of explained variance (23 and $38 \%$ in the diverse and grass swards in 2008, respectively) than the actual treatment factors ( 7 and $5.6 \%$ in the diverse and grass sward in 2008, respectively), spatial factors were considered as covariables in analyses. For the analyses of significant effects of time or its interaction with treatment factors on changes in species composition, repeated measures RDAs were performed as described in Lepš and Šmilauer (2003); all canonical axes were tested under the reduced model with 499 permutations. If a significant effect was found, the analysis was repeated with automatic selection of variables to identify the significant variables or interactions. Tables of species-by-environmental correlations were used to detect relationships between plant species abundances and grazing treatments (ter Braak and Šmilauer, 2002b). Signficant correlations of plant species with grazing treatments were assessed by t-value biplots on partial RDAs of the grass and diverse sward (ter Braak and Šmilauer, 2002c).

To measure vegetation similarity, DCAs for grazing treatments on the paddock level were performed to determine the standard deviation of species turnover given as the length of the first axis of the DCA (Hill and Gauch, 1980), and the Bray-Curtis distance between samples was determined as the sum of differences in species abundances between two samples $\mathrm{y}_{1}$ and $\mathrm{y}_{2}$, divided by the sum of species abundances in these two samples (ter Braak and Šmilauer, 2002a):

$\mathrm{D}_{12}=\left(\Sigma\left|\mathrm{y}_{1}-\mathrm{y}_{2}\right|\right) /\left(\Sigma\left(\mathrm{y}_{1}+\mathrm{y}_{2}\right)\right)$.

Further statistical analyses were carried out with R (2.7.2, 2008). Univariate analyses were performed with linear mixed effects models (block as random factor, sward type and grazing animal as fixed factors; year as repeated measurement) with post hoc Tukey adjustments to investigate differences among sward types and grazing treatments in mean numbers of plant species, yield proportions of single species, legume and forb yield, Shannon diversity and Bray-Curtis distance and trampling tolerance of the vegetation (Klotz et al., 2002b). For analyses of treatment effects on VC and sward height, ANCOVAs were performed with the respective post-grazing values as response and pre-grazing values of the first grazing cycle as co-variables. In 2007, only means of pre-grazing sward heights of the first cycle were noted, 
therefore, post-grazing sward height was only analysed for 2008 and 2009. Common visual tests like the normal QQ plot (test of normality) and the residuals versus fitted values plot (test of variance homogeneity) were used to test the assumptions for a parametric test (Dormann and Kühn, 2008). Non-parametrical data were analysed by Kruskal-Wallis tests. 


\section{Results}

As vegetation composition in 2007 was measured as presence/absence data which makes it difficult to compare to results from the following years, here, we present data on vegetation composition from 2008 and 2009. In 2008, grazing treatments had no effect on vegetation composition. In 2009, cattle grazing had a significant effect on vegetation composition in the diverse $(P=0.050)$ and grass swards $(P=0.025$, determined by Monte Carlo permutation in an RDA). Sheep and co-grazing had no significant effect on vegetation composition; cograzed paddocks were intermediate between cattle- and sheep-grazed paddocks in the diverse and grass swards (Fig. 1a and 1b, Tab. 1).

In both swards, plant species correlations differed for grazing cattle and sheep; co-grazing led to species reactions intermediate between the mono-grazed treatments or were, in tendency, more similar to those in the cattle treatment (Tab. 1). T. repens occurred in higher abundances in cattle than in sheep-grazed grass (not significant) and diverse $(P \leq 0.05$, determined by $\mathrm{t}$ value biplot) paddocks. In the grass sward, the grasses Phleum pratense and Poa trivialis showed smaller proportions in the sheep than in the cattle treatment. In the diverse sward, there were larger occurrences of Crepis biennis in sheep- and co-grazed than in the cattlegrazed paddocks. In both swards, larger abundances of Lolium perenne and smaller abundances of $D$. glomerata were found in the cattle- compared to the sheep-grazed treatment. Sheep-grazing was positively correlated to occurrences of Festuca rubra in the grass and negatively in the diverse sward.

Sward type and year had significant effects on vegetation composition (sward effect: $P=$ 0.001 in 2008 and $P=0.005$ in 2009; year effect: $P=0.002$ in the grass and $P=0.008$ in the diverse sward, determined by analyses 1 and 2, see Tab. 2) and accounted for the two most important gradients found for vegetation composition (data not shown). There was no significant interaction between grazing treatment and year on vegetation composition (analyses 3 and 4, respectively; Tab. 2), i.e. the temporal change in vegetation composition did not differ among grazing treatments within sward types. As a tendency the explained variance in vegetation composition by grazing treatments was larger in the grass $(7.5 \%)$ compared to the diverse sward (6\%; data not shown).

From 2007 to 2009 , the yields of both legumes $(P=0.016)$ and forbs $(P=0.002)$ increased in the diverse sward, by 4 and $28.6 \%$ in cattle- and by 5 and $31.8 \%$ in co-grazed paddocks, respectively. 

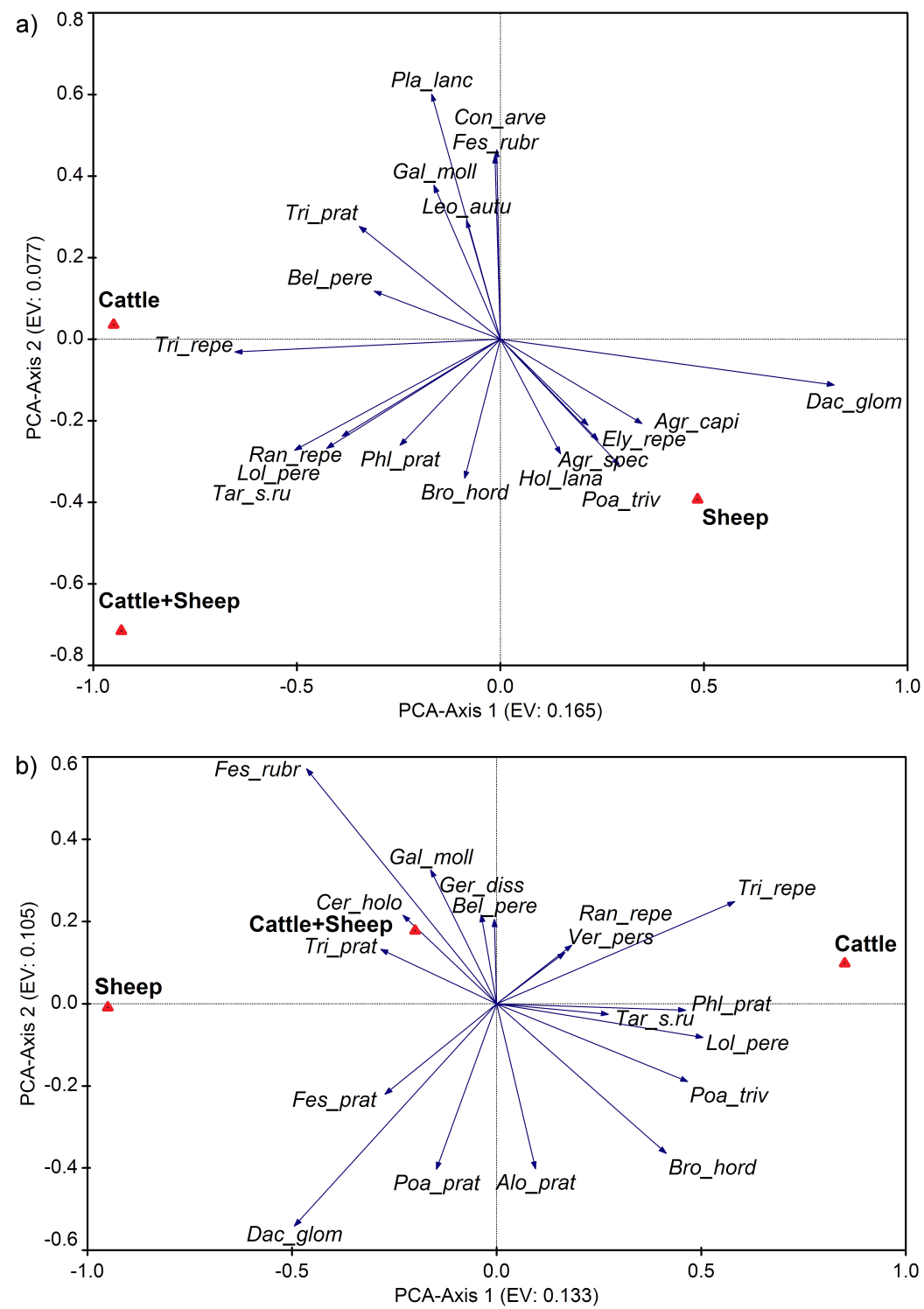

Figure 1: PCA diagrams (data log transformed) of plant species (arrows) and environmental variables (triangles: grazing treatments; covariables: spatial factors) for the diverse (a) and grass sward (b) after two years of differential grazing in 2009. Axes 1 and 3 explain 16.5 or 13.3 and 6.5 or $8.0 \%$ of the vegetation variance in the diverse and grass swards, respectively. Species within a fit range of 9-100\% (a) or 4-100 \% (b) are displayed in the species ordination. Species names are abbreviated with the 3+4 first letters. Agr_capi: Agrostis capillaris, Agr_spec: Agrostis spec. (A. stolonifera and A. gigantea), Alo_prat: Alopecurus pratensis, Bel_pere: Bellis perennis, Bro_hord: Bromus hordeaceus, Cer_holo: Cerastium holosteoides, Cir_arve: Cirsium arvense, Cre_bien: Crepis biennis, Dac_glom: Dactylis glomerata, Ely_repe: Elymus repens, Fes_prat: Festuca pratense, Fes_rubr: Festuca rubra, Gal_moll: Gallium mollugo, Hol_lana: Holcus lanatus, Lol_mult: Lolium multiflorum, Lol_pere: Lolium perenne, Phl_prat: Phleum pratense, Poa_humi: Poa humilis, Poa_triv: Poa trivialis, Ran_repe: Ranunculus repens, Tar_s.Ru: Taraxacum sect. Ruderalia, Tri_prat: Trifolium pratense, Tri_repe: Trifolium repens, Ver_pers: Veronica persica, Ver_serp: Veronica serpyllifolia. 
Table 1: Plant species correlations with grazing treatments (C: cattle, S: sheep, CS: both) in grass and diverse sward. Correlations were extracted from species-by-environmental correlations data file of RDAs (variables: grazing treatments; covariables: spatial variables); NV: nutritional value. Correlation coefficients are shown if a treatment reached a value $\geq 0.40$.

\begin{tabular}{cccccccc}
\hline & & \multicolumn{3}{c}{ Grass sward } & \multicolumn{3}{c}{ Diverse sward } \\
\cline { 3 - 8 } & NV & C & S & CS & C & S & CS \\
\hline Trifolium repens & 9 & 0.340 & -0.537 & -0.137 & 0.835 & -0.658 & 0.176 \\
Phleum pratense & 9 & 0.462 & -0.498 & -0.036 & & & \\
Poa trivialis & 7 & 0.401 & -0.326 & 0.075 & & & \\
Lolium perenne & 9 & 0.418 & 0.010 & 0.423 & 0.369 & -0.125 & 0.244 \\
Festuca rubra & 6 & -0.251 & 0.510 & 0.259 & 0.210 & -0.396 & -0.186 \\
Dacytylis glomerata & 8 & -0.692 & 0.496 & -0.195 & -0.464 & 0.112 & -0.353 \\
Crepis biennis & 5 & & & & -0.011 & 0.408 & 0.397 \\
\hline
\end{tabular}

Table 2: Results of RDA analyses for years 2008 and 2009 for single swards to determine effects of year $(\mathrm{Y})$ and its interaction with treatment factors (C: cattle, S: sheep, CS: co-grazing) on changes in plant species composition. \% expl. 1st axis: proportion of explained species variation of the first canonical axis; $r$ 1st axis: species-environment correlation on the first axis; $F$ ratio: F-ratio statistics on the trace (sum of canonical eigenvalues).

\begin{tabular}{|c|c|c|c|c|c|c|c|c|}
\hline & Data & $\begin{array}{c}\text { Analy- } \\
\text { sis }\end{array}$ & Explanatory variables & Covariables & $\begin{array}{l}\% \text { expl. } \\
1 \text { st axis }\end{array}$ & $r$ 1st axis & $F$ ratio & $P$ \\
\hline \multirow{2}{*}{$\begin{array}{l}\text { Temporal trend } \\
\text { in vegetation } \\
\text { change? }\end{array}$} & Grass & 1 & $\mathrm{Y}, \mathrm{Y} * \mathrm{C}, \mathrm{Y} * \mathrm{~S}, \mathrm{Y} * \mathrm{CS}$ & PlotID & 8.3 & 0.95 & 8.37 & 0.016 \\
\hline & Diverse & 2 & $\mathrm{Y}, \mathrm{Y} * \mathrm{C}, \mathrm{Y} * \mathrm{~S}, \mathrm{Y} * \mathrm{CS}$ & PlotID & 9.0 & 0.97 & 8.82 & 0.018 \\
\hline \multirow{2}{*}{$\begin{array}{l}\text { Is the temporal } \\
\text { trend dependent } \\
\text { on grazing } \\
\text { treatment? }\end{array}$} & Grass & 3 & $\mathrm{Y}^{*} \mathrm{C}, \mathrm{Y} * \mathrm{~S}, \mathrm{Y} * \mathrm{CS}$ & PlotID, Y & 0.9 & 0.62 & 1.88 & 0.270 \\
\hline & Diverse & 4 & $\mathrm{Y}^{*} \mathrm{C}, \mathrm{Y} * \mathrm{~S}, \mathrm{Y} * \mathrm{CS}$ & PlotID, Y & 0.6 & 0.44 & 1.40 & 0.784 \\
\hline
\end{tabular}

In sheep-grazed paddocks, the yield of forbs increased (by $19.4 \%$ ) and that of legumes decreased (from initially 10.8 to $2.1 \%$ in 2009; Fig. 2). In 2009, the legume abundance was higher in tendency in cattle- and co-grazed compared to sheep-grazed paddocks (by 5 and 6\%, respectively, Fig. 2$)$, though this effect was not significant $(P=0.232)$. In the grass sward, yield percentages of forbs increased significantly $(P=0.020)$; in tendency, dicots reached larger levels in cattle- and sheep- compared to co-grazed grass paddocks in 2009. 


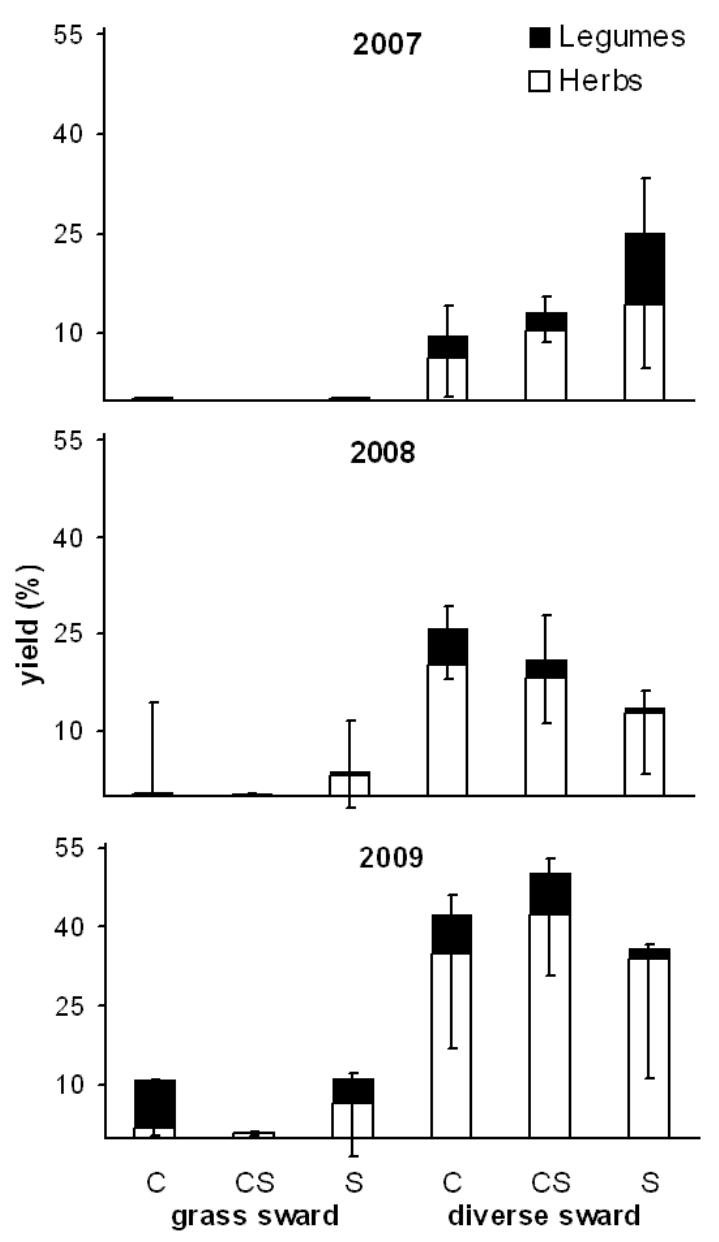

Figure 2: Mean yield proportions (\%) of herbs (white, - sd) and legumes (black, + sd) on cattle, cograzed and sheep (C, CS, S) grass and diverse swards before (2007) and after one and two years of grazing (2008 and 2009, respectively).

Some species with high trampling tolerance increased in abundance from 2008 to 2009, e.g. Lolium perenne $(P<0.001)$, Trifolium repens $(P=0.010)$, Taraxacum sect. Ruderalia $(P<$ 0.001), and Poa trivialis $(P<0.001)$ in both sward types; Poa pratensis $(P=0.026)$ increased in the diverse sward (Tab. 3). There was no significant difference in trampling tolerance of the vegetation among grazing treatments in 2008 or 2009.

There was a significant effect of the interaction between sward type and grazing treatment on post-grazing vegetation height $(P<0.001$ for the second and third grazing cycles in 2008 and all grazing cycles in 2009). In the grass sward, post-grazing sward heights were significantly larger in cattle- (second grazing cycle 2008) or in cattle- and co-grazed paddocks (third grazing cycle 2008) than in the sheep-grazed treatment (Tab. 4). In the diverse sward, postgrazing sward heights were significantly larger in sheep- and cattle- (second grazing cycle 2008) or in sheep- and co-grazed treatments (third grazing cycle 2008) than in the respective other grazing treatments $(P<0.001$ in both cycles; Tab. 4). In 2009, similar results were found, with significantly larger post-grazing sward heights in cattle-grazed grass or sheep- 
grazed diverse paddocks, and co-grazed treatments being similar to cattle-grazed paddocks in the grass sward or to sheep-grazed paddocks in the diverse sward (data not shown).

Table 3: Yield proportions of plant species (mean $\pm \mathrm{sd}$ ) that are trampling tolerant after one and two years of mono- and co-grazing (C: cattle, S: sheep, CS: both) on diverse and grass swards. Signficant differences among grazing treatments within one sward type are indicated by superscript letters, sward $(\mathrm{Sw})$ and year $(\mathrm{Y})$ effects are given in the last columns (ns: not significant; *: $P \leq 0.05$; **: $P \leq 0.01$; ***: $P \leq 0.001)$. Year effects were analysed by repeated measurement ANOVAs. There were no interactions between sward and grazing treatment.

\begin{tabular}{cccccccccc}
\hline & \multicolumn{3}{c}{ Diverse sward } & \multicolumn{3}{c}{ Grass sward } & & \\
\cline { 2 - 9 } & & $\mathbf{C}$ & $\mathbf{C S}$ & S & $\mathbf{C}$ & $\mathbf{C S}$ & $\mathbf{S}$ & Sw & $\mathbf{Y}$ \\
\hline Lolium perenne & 2008 & $25.9 \pm 7.8$ & $29.8 \pm 6.1$ & $23.3 \pm 6.4$ & $27.5 \pm 6.4$ & $21.2 \pm 3.7$ & $24.1 \pm 5.5$ & $\mathrm{~ns}$ & $* * *$ \\
& 2009 & $17.1 \pm 13.3$ & $20.6 \pm 4.7$ & $9.3 \pm 2.9$ & $13.2 \pm 2.3^{\mathrm{a}}$ & $27.7 \pm 6.3^{\mathrm{b}}$ & $10.5 \pm 5.1^{\mathrm{a}}$ & $\mathrm{ns}$ & \\
Trifolium repens & 2008 & $5.0 \pm 3.5^{\mathrm{b}}$ & $2.3 \pm 2.0^{\mathrm{b}}$ & $0.6 \pm 0.6^{\mathrm{a}}$ & $0.2 \pm 0.1$ & $0.1 \pm 0.1$ & $0.2 \pm 0.2$ & $\mathrm{~ns}$ & $* *$ \\
& 2009 & $6.4 \pm 3.3$ & $7.1 \pm 6.2$ & $1.3 \pm 1.3$ & $8.9 \pm 13.9$ & $0.2 \pm 0.1$ & $1.7 \pm 2.6$ & $\mathrm{~ns}$ & \\
Poa pratensis & 2008 & $1.7 \pm 0.6$ & $2.0 \pm 1.4$ & $1.6 \pm 1.7$ & $1.4 \pm 0.7$ & $2.0 \pm 1.9$ & $3.6 \pm 1.7$ & $\mathrm{~ns}$ & $* *$ \\
& 2009 & $3.6 \pm 3.0$ & $3.5 \pm 2.3$ & $2.8 \pm 1.3$ & $3.8 \pm 2.9$ & $5.9 \pm 3.1$ & $5.5 \pm 5.3$ & $\mathrm{~ns}$ & \\
Taraxacum sect. & 2008 & $11.9 \pm 10.0$ & $14.7 \pm 7.4$ & $7.1 \pm 9.2$ & $0.1 \pm 0.1$ & $0.1 \pm 0.0$ & $0.2 \pm 0.1$ & $* * *$ & $* * *$ \\
Ruderalia & 2009 & $25.7 \pm 27.2$ & $34.3 \pm 1.8$ & $23.2 \pm 25.4$ & $1.0 \pm 0.6$ & $0.4 \pm 0.2$ & $1.1 \pm 0.8$ & $* * *$ & \\
Poa trivialis & 2008 & $11.9 \pm 5.6^{\mathrm{a}}$ & $20.2 \pm 5.5^{\mathrm{ab}}$ & $27.8 \pm 6.6^{\mathrm{b}}$ & $25.1 \pm 6.8$ & $27.1 \pm 9.1$ & $20.7 \pm 10.3$ & $\mathrm{~ns}$ & $* * *$ \\
& 2009 & $1.6 \pm 0.3^{\mathrm{a}}$ & $1.9 \pm 0.5^{\mathrm{ab}}$ & $3.1 \pm 0.2^{\mathrm{b}}$ & $4.7 \pm 4.4$ & $3.9 \pm 2.6$ & $2.0 \pm 1.0$ & $\mathrm{~ns}$ & \\
\hline
\end{tabular}

Table 4: ANOVA summary of post-grazing sward height across treatments and for grass and diverse sward separately, at the second and third grazing cycle in 2008 (C2 and C3). Sward height before the first grazing cycle (covariable) was considered as first, the block as second factor before the grazing treatment (ns: not significant); post-grazing sward height was box.cox-transformed to achieve normal distribution of residuals.

\begin{tabular}{cccccc}
\hline & & \multicolumn{3}{c}{ ANOVA summary, Significance of F-value } & \\
\cline { 5 - 6 } Date & Sward type (St) & Grazing treatment (G) & St x G & Grass sward & Diverse sward \\
\hline 2008, C2 & 0.038 & $<0.001$ & G & G \\
2008, C3 & $\mathrm{ns}$ & 0.009 & $<0.001$ & $<0.001$ & $<0.001$ \\
& & &
\end{tabular}

The sward height variability, measured as the coefficient of variation (CV) of sward height, was in some cases larger in the diverse compared to the grass sward, e.g. at the first and third grazing cycle in 2008 ( $P=0.022$ and $P=0.018$, respectively) and the second grazing cycle in $2009(P=0.043)$, but was similar between swards at the other grazing cycles (data not shown). The CV was significantly larger in cattle- than in co-grazed diverse paddocks at the second grazing cycle in $2008(P=0.019)$ and significantly larger in the cattle- than in the 
sheep-grazed grass paddocks at the third grazing cycle in 2009 ( $P=0.030$; data not shown); at the other grazing cycles, no difference in $\mathrm{CVs}$ among grazing treatments was found.

Initial differences in plant species numbers between diverse and grass swards $(P<0.001$ and $P=0.035$ in 2007 and 2008, respectively) decreased over time (Tab. 5). The Shannon index differed for the grass and diverse swards $(P=0.032)$, but was not affected by different grazing treatments. The Bray-Curtis distance did not differ between swards or among grazing treatments within both swards, but increased significantly from 2008 to $2009(P<0.001$; Tab. 5). The standard deviation of species turnover, determined by gradient lengths of DCAs, did not differ significantly between swards or among grazing treatments within sward types in 2008 and 2009 (Tab. 5).

Table 5: Plant species numbers (based on $9 \mathrm{~m}^{2}$ ), Shannon diversity index, Bray-Curtis distance, gradient lengths of DCAs and trampling tolerance of the vegetation (mean $\pm \mathrm{sd}$ ) in the first year and/or after one and two years of grazing. Sward $(\mathrm{Sw})$ and year $(\mathrm{Y})$ effects are given in the respective columns (ns: not significant; $*: P \leq 0.05$; $* * *: P \leq 0.001$ ). Year effects were analysed by repeated measurement ANOVAs. There were no interactions between sward and grazing treatment except for trampling tolerance in $2008(P=0.017)$.

\begin{tabular}{|c|c|c|c|c|c|c|c|c|c|}
\hline & & \multicolumn{3}{|c|}{ Diverse sward } & \multicolumn{3}{|c|}{ Grass sward } & \multirow[b]{2}{*}{ Sw } & \multirow[b]{2}{*}{$\mathbf{Y}$} \\
\hline & & C & CS & $\mathbf{S}$ & C & $\mathrm{CS}$ & $\mathbf{S}$ & & \\
\hline \multirow[t]{3}{*}{ Plant species number } & 2007 & $13.8 \pm 2.4$ & $13.3 \pm 2.2$ & $14.2 \pm 5.6$ & $9.3 \pm 2.5$ & $8.73 \pm 1.8$ & $9.7 \pm 2.7$ & $* * *$ & *** \\
\hline & 2008 & $18.3 \pm 5.4$ & $15.5 \pm 1.3$ & $14.9 \pm 4.6$ & $11.9 \pm 0.5$ & $12.1 \pm 1.6$ & $13.7 \pm 5.3$ & $*$ & \\
\hline & 2009 & $14.3 \pm 0.3$ & $14.2 \pm 2.1$ & $14.9 \pm 4.2$ & $15.5 \pm 2.0$ & $13.5 \pm 2.3$ & $15.3 \pm 3.6$ & ns & \\
\hline \multirow[t]{2}{*}{ Shannon } & 2008 & $2.0 \pm 0.2$ & $1.9 \pm 0.2$ & $1.7 \pm 0.3$ & $1.5 \pm 0.2$ & $1.7 \pm 0.2$ & $1.7 \pm 0.3$ & $*$ & $* * *$ \\
\hline & 2009 & $1.6 \pm 0.5$ & $1.7 \pm 0.4$ & $1.5 \pm 0.4$ & $1.5 \pm 0.3$ & $1.6 \pm 0.3$ & $1.5 \pm 0.4$ & $\mathrm{~ns}$ & \\
\hline \multirow[t]{2}{*}{ Bray-Curtis } & 2008 & $0.4 \pm 0.1$ & $0.4 \pm 0.1$ & $0.4 \pm 0.2$ & $0.4 \pm 0.0$ & $0.4 \pm 0.0$ & $0.4 \pm 0.1$ & $\mathrm{~ns}$ & $* * *$ \\
\hline & 2009 & $0.5 \pm 0.1$ & $0.5 \pm 0.1$ & $0.5 \pm 0.2$ & $0.6 \pm 0.1$ & $0.5 \pm 0.0$ & $0.6 \pm 0.2$ & $\mathrm{~ns}$ & \\
\hline \multirow[t]{2}{*}{ DCA gradient length } & 2008 & $1.3 \pm 0.1$ & $1.1 \pm 0.3$ & $1.3 \pm 0.6$ & $1.1 \pm 0.0$ & $1.0 \pm 0.1$ & $1.0 \pm 0.3$ & ns & $* * *$ \\
\hline & 2009 & $1.4 \pm 0.1$ & $1.3 \pm 0.1$ & $1.7 \pm 0.8$ & $1.7 \pm 0.3$ & $1.3 \pm 0.2$ & $1.5 \pm 0.4$ & ns & \\
\hline \multirow[t]{2}{*}{ Trampling tolerance } & 2008 & $6.5 \pm 0.4$ & $6.7 \pm 0.1$ & $6.3 \pm 0.2$ & $6.4 \pm 0.4$ & $6.2 \pm 0.3$ & $6.5 \pm 0.1$ & ns & ns \\
\hline & 2009 & $6.4 \pm 0.9$ & $6.7 \pm 0.7$ & $6.0 \pm 0.9$ & $6.8 \pm 0.4$ & $6.9 \pm 0.3$ & $6.4 \pm 0.5$ & ns & \\
\hline
\end{tabular}




\section{Discussion}

In this study, initial effects of mono- and co-grazing cattle and sheep on the vegetation development of swards with different composition were analysed. Spatial parameters had a strong effect on vegetation composition, explaining 67 or $71 \%$ of the total explained variance in 2008 and 2009, respectively. Nevertheless, constrained analyses considering spatial effects as covariables confirmed our hypothesis of grazing animal effects on vegetation composition: cattle-grazing significantly affected vegetation composition. Sheep- and co-grazing, however, did not significantly change vegetation composition, and co-grazed paddocks were intermediate in composition between cattle- and sheep-grazed paddocks (Fig. 1a and 1b, Tab. $1)$.

Our data suggest larger forage selectivity by sheep and different foraging strategies by both cattle and sheep to contribute to compositional differences among the mono-grazed treatments. The effect of animal treading, however, measured as the mean trampling tolerance of the vegetation, was unaffected by grazing treatment -likely due to similar grazing intensity among treatments- and did not change with time, even though some treading tolerant plant species like L. perenne and P. trivialis increased significantly from 2008 to 2009.

Legume proportions decreased in sheep-grazed paddocks in the diverse swards from 2007 to 2009, and -consistent with other studies (Dumont et al., 2010; Nolan et al., 2001)- T. repens abundances were smaller in sheep- compared to cattle-grazed treatments in 2009 , likely due to selective grazing by sheep (Curll and Wilkins, 1983). In both swards, cattle-grazing coincided with higher Lolium perenne abundances than sheep-grazing. Sheep seemed to have grazed indifferently on $L$. perenne (correlations were around zero in both swards, see Tab. 1). In cattle-grazed paddocks, this high-digestible grass species increased in yield, possibly because it had been avoided in latrine areas.

In the grass sward, there is less possibility for selective behaviour, and sheep, normally avoiding forage with high crude fibre content (Thomas et al., 2010), seemed to have selected for the highly digestible grass $P$. pratense and -to less extent- $P$. trivialis, that were both grazed indifferently by sheep in the diverse swards. F. rubra, a grass of lower digestibility, was refused by sheep grazing grass swards, whereas cattle seemed to have grazed on F. rubra to a larger amount.Sheep seemed to have fed selectively on F. rubra in the diverse swards. In block C, F. rubra was one of the dominating grasses (average yield proportion of $19 \%$ ). A small range of choices might have led to the sheep's increased feeding on that grass. $D$. glomerata was reduced in the cattle- and, to less extent, in the co-grazed grass and diverse 
swards whereas it seemed to have been avoided by sheep in the grass sward. Selective feeding on D. glomerata in the co-grazed diverse treatment was also observed in another investigation in the same experiment (Cuchillo and Isselstein, 2010). The authors suggested that animals selected species of higher fibre content when grazing in the diverse swards. Interestingly, they did not find this effect -contrary to our results- in the cattle-grazed grass and diverse paddocks, probably due to the smaller spatial scale of measurement ( $0.5 \mathrm{vs} .1 \mathrm{~m}^{2}$ in our study) leading to different results particularly in the patchily-grazed cattle paddocks.

Our hypothesis of a better utilisation of the sward in the co-grazed compared to the monograzed paddocks was not confirmed. Post-grazing sward heights in co-grazed paddocks were not smaller compared to the mono-grazed treatments, but were either similar to the cattle- or sheep-grazed treatment. The CV of sward height was not smaller in the co-grazed treatment either (with exception of the second grazing cycle in 2008), which would have been an indication of a more even utilisation of the sward. Even though in tendency smaller gradient lengths of DCAs in the co-grazed than in the mono-grazed paddocks in the diverse sward in 2008 and 2009 and in the grass sward in 2009 hint at a higher vegetation similarity in this treatment, the Bray-Curtis distance did not differ among grazing treatments. In other studies, co-grazing or sequential grazing of cattle and sheep was found to result in better animal performance (Abaye et al., 1994; Fraser et al., 2007); co-grazing cattle and horses increased plant diversity in the long term related to a more complementary sward use (Loucougaray et al., 2004). More stable forage biomass, more possibilities of selective foraging by sheep and complementary grazing were discussed as underlying mechanisms for higher animal performance in co-grazed paddocks. In our study, however, neither distinct differences in the sward structure between co-grazed and mono-grazed treatments nor hints to more stable productivity were detected. Experimental sites of the before mentioned studies were grazed continuously at relatively low stocking rates (around 2.4 LU ha ${ }^{-1}$, respectively), while our site was grazed rotationally at higher grazing pressure (between 13.7 and $8.6 \mathrm{LU} \mathrm{ha}^{-1}$ ). This resulted in less forage availability and less possibility for selective and complementary behaviour.

We found evidence confirming our hypothesis of different grazing effects by cattle and sheep depending on the sward type. In the grass sward, post-grazing sward height was significantly larger in cattle- than in sheep-grazed paddocks, whereas in the diverse sward, it was vice versa (with exception of the second grazing cycle in 2008, when post-grazing sward height was significantly larger in cattle- and sheep- than in co-grazed paddocks). In the grass swards, the possibility of selective behaviour is limited. This may have led to preferential grazing by 
sheep on short, vegetative sward areas, in order to increase their digestible dry matter intake, as proposed by Thomas et al. (2010). In the diverse sward, however, the crude fibre content of the forage was lower compared to the grass plots and cattle, coping better with low forage quality, seem to have increased their forage intake, resulting in smaller post-grazing sward heights. The two sward types seem to have been differently affected by grazing treatments with respect to functional group abundances: While cattle- and co-grazing facilitated larger proportions of dicots in the diverse sward, the invasion of dicots was strongest in both monograzed treatments in the grass sward. The repeated grazing by cattle on short sward areas (Dumont et al., 2007) likely created the niches for the establishment of dicots. Stewart et al. (2006) stated in their review on grazed Cynosurus cristatus - Centaurea nigra grassland, that sward height is linked to forb abundance and has to be larger in sheep- compared to cattlegrazed pastures for a promotion of forbs. Contrary to the finding of Stewart et al. (2006), dicot invasion on sheep-grazed grass paddocks was strong, although post-grazing sward heights in sheep-grazed grass paddocks were similar or even shorter than those of sheep-grazed diverse paddocks, indicating that sufficient sward height was not an explanation for a dicot increase in the sheep-grazed grass paddocks. Foraging to lower sward heights may have reduced the competitive ability of grasses, creating niches for less competitive dicot species. Minor availability and lower visibility of the preferred forb and legume species in the grass compared to the diverse sward probably also decreased their intake by sheep (Dumont et al., 1998) in our study.

Unfortunately, no data of yield proportions on plant species level were available for 2007, making it impossible to assure that there were no initial differences in vegetation composition prior to the start of the experiment. Even though Festuca pratense occurred more and Elymus repens less frequently in the co-grazed paddocks compared to the other treatments before the start of the experiment, the yield abundances of these species and the vegetation composition among grazing treatments did not differ in 2008. Therefore, the significant effect of cattlegrazing on vegetation composition observed in 2009 could not have resulted from initial compositional differences. Yet, given the fact that the vegetation development in response to management may take decades (Gibson and Brown, 1992), it is astonishing to find such strong grazing effects after only two years of different management. Since sheep affect the vegetation by facilitating the presence of certain species (Sebastià et al., 2008), significant grazing effects by sheep on vegetation composition may take a longer time period to develop. 


\section{Conclusions}

Initial results of differential grazing management on vegetation composition showed significant changes in mono-grazed cattle paddocks. Co-grazed paddocks were intermediate in vegetation composition between cattle- and sheep-grazed paddocks. In the diverse swards, cattle- and co-grazed paddocks had larger dicot proportions than the sheep-grazed treatment. In the grass sward, dicot abundance increased notably in sheep and cattle mono-grazed paddocks, likely the effect of cattle creating niches for dicots by patch grazing and worse conditions for selective behaviour by sheep.

Mono-grazing by cattle and sheep affected post-grazing sward height differently depending on the sward type. The decrease of legumes in both sward types and the reduction of highly digestible grasses in the grass sward in sheep-grazed paddocks hint at selective feeding by sheep. Sheep-grazing did not change vegetation composition significantly after two years of grazing. Co-grazing did not lead to a more efficient utilisation of the sward and did not result in higher plant diversity. Apart from facilitation of dicot abundance and effects on sward structure, no other cause of vegetation change in cattle paddocks could be identified.

Our results point to different foraging behaviour by cattle and sheep as a function of sward composition and grazing animal need. Vegetation changes in response to co-grazing cattle and sheep may take a long time to develop.

\section{Acknowledgements}

We thank B. Greune for support with vegetation surveys, B. Hohlmann for technical assistance and C. Scherber for statistical advice. 


\section{References}

Abaye, A.O., V.G. Allen, and J.P. Fontenot. 1994. Influence of grazing cattle and sheep together and separately on animal performance and forage quality. J. Anim Sci. 72:1013-1022.

Animut, G., A.L. Goetsch, G.E. Aiken, R. Puchala, G. Detweiler, C.R. Krehbiel, R.C. Merkel, T. Sahlu, L.J. Dawson, Z.B. Johnson, and T.A. Gipson. 2005. Performance and forage selectivity of sheep and goats co-grazing grass/forb pastures at three stocking rates. Small Ruminant Research 59:203-215.

Bardgett, R.D., D.A. Wardle, and G.W. Yeates. 1998. Linking above-ground and below-ground interactions: how plant responses to foliar herbivory influence soil organisms. Soil Biology and Biochemistry 30:1867-1878.

Borcard, D., and P. Legendre. 1994. Environmental control and spatial structure in ecological communities: an example using oribatid mites (Acari, Oribatei). Environmental and Ecological Statistics 1:37-61.

Castle, M.E. 1976. A simple disc instrument for estimating herbage yield. Journal of the British Grassland Society 31: 37-40.

Cuchillo, H.M., and J. Isselstein. 2010. Intake choices of cattle and sheep grazing alone or together on grass swards differing in plant species diversity. Grassland Science in Europe 15:922-924.

Curll, M.L., and R.J. Wilkins. 1983. The comparative effects of defoliation, treading and excreta on a Lolium perenne-Trifolium repens pasture grazed by sheep. The Journal of Agricultural Science 100:451-460.

de Bello, F., J. Lepš, and M.-T. Sebastià. 2005. Predictive value of plant traits to grazing along a climatic gradient in the Mediterranean. Journal of Applied Ecology 42:824-833.

Dennis, P., M.R. Young, and C. Bentley. 2001. The effects of varied grazing management on epigeal spiders, harvestmen and pseudoscorpions of Nardus stricta grassland in upland Scotland. Agriculture, Ecosystems \& Environment 86:39-57.

Denyer, J.L., S.E. Hartley, and E.A. John. 2010. Both bottom-up and top-down processes contribute to plant diversity maintenance in an edaphically heterogeneous ecosystem. Journal of Ecology 98:498-508.

Dormann, C.F., and I. Kühn. 2008. Angewandte Statistik für die biologischen Wissenschaften, http://www.ufz.de/data/deutschstatswork7649.pdf (27.09.2010) [Online]. Available by Helmholtz Zentrum für Umweltforschung-UFZ.

Dumont, B., A. Dutronc, and M. Petit. 1998. How readily will sheep walk for a preferred forage? Journal of Animal Science 76:965-971.

Dumont, B., A.J. Rook, C. Coran, and K.-U. Rover. 2007. Effects of livestock breed and grazing intensity on biodiversity and production in grazing systems. 2. Diet selection. Grass and Forage Science 62:159-171.

Dumont, B., P. Carrère, N. Rossignol, J. Chadoeuf, A. Farruggia, C. Ginane, and F. Louault. 2010. Selective grazing, patch stability and vegetation dynamics in a rotationally-grazed pasture. Grassland Science in Europe 15:937-939.

Forbes, T.D.A., and J. Hodgson. 1985. The reaction of grazing sheep and cattle to the presence of dung from the same or the other species. Grass and Forage Science 40:177-182.

Fraser, M.D., D.A. Davies, J.E. Vale, W.M. Hirst, and I.A. Wright. 2007. Effects on animal performance and sward composition of mixed and sequential grazing of permanent pasture by cattle and sheep. Livestock Science 110:251-266.

Fuhlendorf, S., and F. Smeins. 1998. The influence of soil depth on plant species response to grazing within a semi-arid savanna. Plant Ecology 138:89-96.

Gibson, C.W.D., and V.K. Brown. 1992. Grazing and vegetation change: Deflected or modified succession? Journal of Applied Ecology 29:120-131.

Grime, J.P., and J.M.L. Mackey. 2002. The role of plasticity in resource capture by plants. Evolutionary Ecology 16:299-307.

Hayes, G.F., and K.D. Holl. 2003. Cattle grazing impacts on annual forbs and vegetation composition of mesic grasslands in California. Conservation Biology 17:1964-1702. 
Hejcman, M., I. Žáková, M. Bílek, P. Bendová, P. Hejcmanová, V. Pavlu, and M. Stránská. 2008. Sward structure and diet selection after sheep introduction on abandoned grassland in the Giant Mts, Czech Republic. Biologia 63:506-514.

Hill, M.O., and H.G.J. Gauch. 1980. Detrended correspondence analysis: an improved ordination techique. Vegetatio 42:47-58.

Hofmann, M., and J. Isselstein. 2004. Seedling recruitment on agriculturally improved mesic grassland: the influence of disturbance and management schemes. Applied Vegetation Science 7:193-200.

Isselstein, J., B. Jeangros, and V. Pavlu. 2005. Agronomic aspects of biodiversity targeted management of temperate grasslands in Europe- a review. Agronomy Research 3:139-151.

Kahmen, S., P. Poschlod, and K.-F. Schreiber. 2002. Conservation management of calcareous grasslands. Changes in plant species composition and response of functional traits during 25 years. Biological Conservation 104:319-328.

Klapp, E., and A. Stählin. 1936. Standorte, Pflanzengesellschaften und Leistung des Grünlandes. Ulmer, Stuttgart.

Klotz, S., I. Kühn, and W. Durka. 2002a. BIOLFLOR - Eine Datenbank zu biologisch-ökologischen Merkmalen der Gefäßpflanzen in Deutschland. Schriftenreihe für Vegetationskunde (Bundesamt für Naturschutz, Bonn) 38:41-281.

Lepš, J., and P. Šmilauer. 2003. Multivariate analysis of ecological data using CANOCO (pp.219) Cambridge University Press, Cambridge.

Leyer, I., and K. Wesche. 2008. Multivariate Statistik in der Ökologie: Eine Einführung. p.79. Springer, Heidelberg.

Loucougaray, G., A. Bonis, and J.-B. Bouzillé. 2003. Effects of grazing by horses and/or cattle on the diversity of coastal grasslands in western France. Biological Conservation 116:59-71.

Loucougaray, G., A. Bonis, and J.-B. Bouzillé. 2004. Effects of grazing by horses and/or cattle on the diversity of coastal grasslands in western France. Biological Conservation 116:59-71.

Morris, M.G. 2000. The effects of structure and its dynamics on the ecology and conservation of arthropods in British grasslands. Biological Conservation 95:129-142.

Nolan, T., and J. Connolly. 1989. Mixed v. mono-grazing by steers and sheep. Animal Production 48:519-533.

Nolan, T., J. Connolly, and M. Wachendorf. 2001. Mixed grazing and climatic determinants of white clover (Trifolium repens L.) content in a permanent pasture. Annals of Botany 88:713-724.

Nösberger, J., and M. Rodriguez. 1996. Increasing biodiversity through management. Grassland Science in Europe 1:949-956.

Pykälä, J. 2004. Cattle grazing increases plant species richness of most species trait groups in mesic semi-natural grasslands. Plant Ecology 175:217-226.

R. 2.7.2, 2008. The R Foundation for Statistical Computing.

Reyneri, A., G. Pascal, and L.M. Battaglini. 1994. Comparison between sheep and cattle grazing behaviour in native low-mountains pasture. International Centre for Advanced Mediterranean Agronomic Studies (CIHEAM), Options Mediterraneennes, http://ressources.ciheam.org/om/pdf/c05/95605263.pdf (03.10.2010):107-121.

Ribas, A., R. Llurba, D. Ventura, A. Hodge, and M.-T. Sebastià. 2010. Changes in biodiversity composition and soil nutrient content with management in a Pyrenean grassland community. Grassland Science in Europe 15:839-841.

Rogalski, M., and J. Pawska-Olejniczak. 2010. Effect of Scottish Highland cattle grazing on plant communities with Phalaris arundinacea. Grassland Science in Europe 15:1064-1066.

Rook, A.J., and J.R.B. Tallowin. 2003. Grazing and pasture management for biodiversity benefit. Animal Research 52:181-189.

Rook, A.J., B. Dumont, J. Isselstein, K. Osoro, M.F. WallisDeVries, G. Parente, and J. Mills. 2004. Matching type of livestock to desired biodiversity outcomes in pastures - a review. Biological Conservation 119:137-150.

Sebastià, M.-T., F. de Bello, L. Puig, and M. Taull. 2008. Grazing as a factor structuring grasslands in the Pyrenees. Applied Vegetation Science 11:215-222.

Stewart, G.B., and A.S. Pullin. 2006. Does sheep-grazing degrade unimproved neutral grasslands managed as pasture in lowland Britain? Review. Centre for Evidence-Based Conservation, School of Biosciences, University of Birmingham, Edgbaston, Birmingham. 
Plant Research International. 1997-2004. Canoco for Windows. Release 4.53. Plant Research International, Wageningen, The Netherlands.

ter Braak, C.J.F., and P. Šmilauer. 2002a. Reference manual and CanoDraw for windows user's guide: software for canonical community ordination (version 4.5) Microcomputer Power, Ithaca, NY, USA.

ter Braak, C.J.F., and P. Šmilauer. 2002b. Reference manual and CanoDraw for windows user's guide: software for canonical community ordination (version 4.5), p.182. Microcomputer Power, Ithaca, NY, USA.

ter Braak, C.J.F., and P. Šmilauer. 2002c. Reference manual and CanoDraw for windows user's guide: software for canonical community ordination (version 4.5), p.392. Microcomputer Power, Ithaca, NY, USA.

Thomas, D.T., J.T.B. Milton, C.K. Revell, M.A. Ewing, R.A. Dynes, K. Murray, and D.R. Lindsay. 2010. Preference of sheep among annual legumes is more closely related to plant nutritive characteristics as plants mature. Animal Production Science 50:114-123.

Vandvik, V., and H. Birks. 2002. Partitioning floristic variance in Norwegian upland grasslands into within-site and between-site components: are the patterns determined by environment or by land-use? Plant Ecology 162:233-245.

Webb, D.M., O. Abaye, J. Rockett, C. Zipper, C. Teutsch, and G. Scaglia. 2007. Assessing the potential of co-grazing small ruminants with beef cattle to improve utilization of marginal pastureland in Virginia. http://www.cses.vt.edu/PRP/Reports_07/PRP\%20Book\%202007.pdf (23.04.2011). 
Chapter II:

Effects of sward composition and co-grazing on production and quality of herbage

Seither M., Wrage N., Isselstein J. 


\begin{abstract}
In experimental grassland, plant species diversity has often been found to be related to productivity. However, it is not clear whether in an agricultural system with semi-natural permanent grassland, this relationship also exists and how it is affected by the grazing system. We analysed the effects of cattle and sheep grazing alone or in combination on productivity and quality of a moderately species-rich sward (diverse sward) and its grass-dominated counterpart (grass sward) during the first three years after the onset of a grazing experiment. The grass sward was established applying selective herbicides against dicot species before the start of the experiment, resulting in a reduction of plant species number by $35 \%$ and a yield contribution of dicots of less than $1 \%$. Biomass productivity was similar between sward types and was not related to plant diversity, functional group proportion, or grazing treatment. Diverse swards produced higher quality herbage than grass-dominated swards, likely the effect of an increased percentage of highly digestible legumes and forbs. Post-grazing herbage quality was affected by the grazing treatment as a result of selective feeding, with the fiber content being increased and crude protein content decreased by sheep grazing grass or diverse swards. It is concluded that for grazed permanent grassland with a considerable nutrient return via animal excreta and a considerably larger plant species number in the grass sward than usual for low-diversity levels in experimental grassland studies, sward composition is not a strong determinant of sward productivity. However, sward composition as well as grazer species affected herbage quality. So far, co-grazing did not result in a higher herbage quality, but there were indications that co-grazing could have such an effect in the longer term.
\end{abstract}

Key words: grassland, diversity, nitrogen fixation, acid detergent fiber, crude protein, metabolizable energy, sugar content, patchiness, mixed grazing 


\section{Introduction}

Grassland plant diversity has often been suggested to influence ecosystem services like productivity (Hector et al., 1999; Tilman, 1997; Tilman and Downing, 1994). Effects of plant species richness and functional group composition on productivity have been related to nitrogen (N) cycling (Zak et al., 2003), N provision by legumes (Thompson et al., 2005), and the presence of plants with differing growth forms (de Bello et al., 2010) and phenology (Hooper and Vitousek, 1998). Recent research in communities with experimentally assembled plant composition points to less $\mathrm{N}$ leaching with increasing richness of non-leguminous plants (Scherer-Lorenzen et al., 2003), to better nutrient use efficiency (van Ruijven and Berendse, 2005) and nutrient content of herbage (Bullock et al., 2007) in diverse systems. This may be linked to an increased herbage quality, influencing digestibility and herbage consumption by grazing animals (Dewhurst et al., 2009).

Grazing animals affect sward structure and composition, for example by selective feeding (Wallis de Vries and Daleboudt, 1994) and the pattern of excreta return (Rook and Tallowin, 2003). Thus, they can also influence herbage quality and productivity. This effect is likely to differ among animal species. Sheep are more selective (Grant et al., 1987) and need better herbage quality than cattle (Milne, 1991; Rook et al., 2004). Sheep, therefore, strongly prefer plants at a vegetative stage of development; when offered plants at the reproductive stage, they select for herbage with low acid detergent fiber (ADF) and high $\mathrm{N}$ content (Thomas et al., 2010). Cattle, in contrast, also feed on reproductively growing sward patches (Dumont et al., 1995) and dead material (Grant et al., 1987). Thus, the digestibility of diets is usually higher in sheep than in cattle (Dudzinski and Arnold, 1973; Grant et al., 1987). As a result of these differences in selective behaviour, a more rapid decrease in herbage quality in sheepthan in cattle-grazed paddocks seems likely. Large local $\mathrm{N}$ concentrations in cattle dung and urine patches have been found to cause large $\mathrm{N}$ losses (van Groenigen et al., 2005) and to reduce $\mathrm{N}$ fixation rate and legume yield (Ledgard et al., 1982; Vinther, 1998). Excreta nutrients returned by sheep are more evenly distributed than those returned by cattle. Sheep excreta may, therefore, be more efficiently used by plants, with corresponding effects on productivity. However, due to the spatially more even return of $\mathrm{N}$, the $\mathrm{N}$ fixation rate of legumes will be likely to be more reduced in sheep- compared to cattle-grazed paddocks.

Grazing experiments have shown positive effects of co-grazing cattle and sheep on animal performance (Nolan et al., 1989), probably related to a more efficient sward utilisation. The willingness to graze next to dung patches of the respective other species, especially by sheep (Forbes and Hodgson, 1985), and cattle's preference for plant parts avoided by sheep (Wright 
et al., 2001) might cause a more even utilisation of the sward. Smaller proportions of maturing sward of low herbage digestibility (Richards et al., 1962) in cattle-grazed paddocks should increase overall herbage quality (Bakker et al., 1984).

To our knowledge, so far, no studies have investigated the interaction between sward diversity and mono- and co-grazing cattle and sheep on productivity and herbage quality in permanent grasslands. In a three-year study, we investigated initial effects of differential grazing and sward composition on herbage quality and productivity in a semi-natural agriculturally used grassland. The vegetation was either the original moderately species-rich sward or its grassdominated counterpart, established by herbicide application.

Our hypotheses were the following:

I. The productivity is larger in the diverse than in the grass-dominated sward.

a. In the diverse sward, selective feeding on legumes by sheep leads to a decrease of fixed N compared to cattle mono- or co-grazed treatments. However, a resulting potentially negative effect on productivity is matched by a positive effect of a more homogeneous spread of excreta nutrients on the sheep mono- and co-grazed treatments. Thus, we do not expect any marked effect of grazing treatment on productivity in the diverse sward.

b. In the grass sward, the productivity of sheep- and co-grazed paddocks is larger than that of cattle-grazed paddocks, due to the more homogeneous return of sheep excreta and the here missing effect of legumes.

II. Herbage quality is larger in the diverse than in the grass sward due to the presence of legumes and forbs.

a. In the diverse sward, herbage quality is highest in the co-grazed treatment as a result of a more homogeneous grazing stimulating the regrowth of the vegetation. Herbage quality is expected to be poorest in sheep mono-grazed treatments, as sheep select herbage of the highest quality.

b. In the grass sward, the effect of grazing treatment on herbage quality is similar to that described for the diverse sward, but it is less distinct due to less quality differences within the sward and thus less selective grazing by the animals. 


\section{Material and methods}

The experimental site is a moderately species-rich grassland in the Solling Uplands, Germany (51 ${ }^{\circ} 46^{\prime} 47 \mathrm{~N}$ lat, 9 $42^{\prime} 11 \mathrm{E}$ long), assigned to the plant-association Lolio-Cynosuretum (soil type: pelosol, clayey-silty texture). The mean precipitation is $879 \mathrm{~mm}$ and the mean temperature $8.2^{\circ} \mathrm{C}$ per year (1961-1990, Deutscher Wetterdienst, the weather station is located $3 \mathrm{~km}$ from the experimental site). Before the start of the experiment, the site had been used as a mown pasture for more than 16 years; light manure had been applied regularly. Throughout the experiment, neither organic nor mineral fertilizers were applied. Initial soil conditions were determined in July (P, K, Mg) and October 2007 (mineral N analysis) on five composite soil samples per paddock; the sampling depth was 10 or $30 \mathrm{~cm}$, in July or October, respectively. The $\mathrm{pH}$ of the soil was determined in a 2:5 soil to $0.01 \mathrm{M} \mathrm{CaCl}_{2}$ suspension ( $\mathrm{pH}$ : $6.8 \pm 0.3$ ), $\mathrm{P}$ and $\mathrm{K}$ were extracted in 1:20 soil to calcium acetate lactate (continuous flow analyzer [CFA]), $\mathrm{Mg}$ in $1: 10$ soil to $0.0125 \mathrm{M} \mathrm{CaCl}_{2}$ (CFA) and mineral $\mathrm{N}$ in $4: 15$ soil to $1 \mathrm{M}$ $\mathrm{KCl}(\mathrm{CFA})$. The nutrient availability was, as typical for pastures, variable (in $\mathrm{mg} 100 \mathrm{~g}^{-1}$ dry soil: P: $7.9 \pm 3.2, \mathrm{~K}: 17.4 \pm 4.9, \mathrm{Mg}: 35.8 \pm 8.4, \mathrm{NO}_{3}{ }^{-}: 0.5 \pm 0.1, \mathrm{NH}_{4}{ }^{+}: 0.2 \pm 0.0$, means \pm standard deviation, sd), but did not differ significantly among paddocks of different treatments.

In the experiment, the factors sward composition and grazing animal were manipulated. In 2006, half of the naturally 'diverse' paddocks (13.8 \pm 3.7 plant species in 2007, the first experimental year; based on five $9 \mathrm{~m}^{2}$ relevés per paddock) were treated with herbicides against dicotyledonous plants ('Starane' and 'Duplosan KV' with Triclopyr 2-butoxyethylester and Fluroxypyr-1-methylheptyl ester or Methylchlor phenoxypropionic acid as active components, respectively), resulting in grass-dominated 'grass' paddocks $(9.2 \pm 2.5$ species, mean $\pm \mathrm{sd}$ ). Abundant plant species in both swards were Lolium perenne, Dactylis glomerata, Phleum pratense and Festuca pratensis; in the diverse sward, Taraxacum sect. Ruderale and Trifolium repens also occurred frequently. Both sward types were either grazed by calves and cows of the breed German Simmental, by ewes and lambs of Blackheaded and Leine sheep in similar proportions, or by both (co-grazing). Animals were allocated to the paddocks on a live weight basis. Paddocks, each 0.5 ha in size, were grazed rotationally with a grazing pressure of $13.7 \pm 1.4,14.3 \pm 1.6$ and $8.6 \pm 0.6 \mathrm{LU} \mathrm{ha}^{-1}(\mathrm{LU}=$ livestock unit of $500 \mathrm{~kg})$ at the three grazing cycles (mean \pm sd over three years). The grazing season lasted from May to September, interrupted by a six-weeks break for animal mating (between $2^{\text {nd }}$ and $3^{\text {rd }}$ grazing cycle), and varied between $11.1 \pm 3.1,6.1 \pm 2.8$ and $12.3 \pm 1.4$ grazing days for the three cycles (mean \pm sd over the three years) depending on herbage availability. The six 
experimental treatments were replicated three times in blocks (A, B, C) grazed rotationally (two sward types $\mathrm{x}$ three grazing treatments $\mathrm{x}$ three blocks $=18$ paddocks). Fifty measurements of compressed sward height (CSH) per paddock were made with a rising plate meter (Castle, 1976; Correll et al., 2003) before and after each grazing cycle to determine the mean CSH. Simultaneously, four randomly distributed biomass samples of different $\mathrm{CSH}$ per paddock were cut close to the soil surface, dried at $60^{\circ} \mathrm{C}$ for $48 \mathrm{~h}$ and weighed. Block-wise linear regressions between dry weight and $\mathrm{CSH}$ for each grazing cycle were used to calculate standing biomass for the respective treatments (coefficients of determination were $0.64 \pm 0.18$ and $0.55 \pm 0.16$, median \pm sd over the three grazing cycles and years, before and after grazing, respectively).

The annual pasture productivity was determined based on the pre- and post-grazing biomass $\left(\mathrm{DM}_{\text {pre }}\right.$ and $\mathrm{DM}_{\text {post }}$, respectively) of the grazing cycles one and two and the pre-grazing biomass of grazing cycle three (1, 2 and 3 as subscripts) as follows: Annual pasture productivity $=\mathrm{DM}_{\text {pre1 }}+\mathrm{DM}_{\text {pre2 }}+\mathrm{DM}_{\text {pre3 }}-\mathrm{DM}_{\text {post1 }}-\mathrm{DM}_{\text {post2 }}$.

Vegetation growth during grazing of the animals and regrowth after the grazing season were not taken into account; therefore the actual annual pasture productivity was higher than assessed in our study. In the first grazing cycle in 2007, biomass samples for block A were only taken after grazing; in this case, pre-grazing biomass of block A was calculated based on $\mathrm{CSH}$ post-grazing of block $\mathrm{A}$ and $\mathrm{CSH}$ pre-grazing block $\mathrm{B}$.

For analysis of herbage quality (content of crude protein, $\mathrm{CP}$, acid detergent fiber, ADF, water soluble carbohydrates, WSC, and further characteristics needed to calculate the metabolizable energy of the herbage, ME), the biomass samples used to determine pre-grazing biomass were ground to $1 \mathrm{~mm}$ and analyzed by near infrared spectroscopy (NIRS, VDLUFA Qualitätssicherung, Kassel, Germany; Kesting et al., 2009). The crude ash content (CA) was determined by burning subsamples at $550^{\circ} \mathrm{C}$ for 12 hours in a muffle furnace. The ME of the biomass samples was calculated as follows:

$\mathrm{ME}\left(\mathrm{MJ} \mathrm{kg}^{-1}\right)=7.81+0.07559 \mathrm{~Gb}-0.00384 \mathrm{CA}+0.00565 \mathrm{CP}+0.01898 \mathrm{CL}-0.00831$ $\mathrm{ADF}$

with Gb: gas formation, and CL: crude lipid content (GfE, Ausschuss für Bedarfsnormen der Gesellschaft für Ernährungsphysiologie. 2008). The annual $\mathrm{N}$ yield was calculated analogously to the annual pasture productivity: the $\mathrm{N}$ content, determined based on the $\mathrm{CP}$ content, was multiplied with the amount of standing biomass at the respective point of time. Then, the sum of the pre-grazing $\mathrm{N}$ yields of the three cycles was calculated and the postgrazing $\mathrm{N}$ yields of cycle one and two were subtracted. To determine the post-grazing $\mathrm{N}$ 
content of the herbage for 2008 and 2009, the mean difference of pre- and post-grazing $\mathrm{N}$ content per grazing treatment and cycle in 2007 was subtracted from the respective pregrazing $\mathrm{N}$ contents in 2008 and 2009. In case of missing values of pre-grazing $\mathrm{N}$ content, the mean of the other two years for that treatment was used.

The ${ }^{15} \mathrm{~N}$ natural abundance method (Amarger et al., 1979) was used to determine the $\mathrm{N}$ derived from the atmosphere (Ndfa) by legumes. Legume yield proportions were estimated (Klapp and Stählin, 1936) before each grazing event in 2008 and 2009 on 15 randomly distributed points per paddock (each $0.07 \mathrm{~m}^{2}$ in size). Legumes as well as grasses as non-N fixing reference plants were sampled (six combined subsamples per paddock for each) if legumes exceeded $2.7 \%$ of yield. Related to this threshold value, missing values occurred. To allow for statistical analysis of fixed N, mean annual treatment Ndfa values were used in case of missing values. Samples were dried for $48 \mathrm{~h}$ at $60^{\circ} \mathrm{C}$, ground to $0.25 \mathrm{~mm}$ and analyzed with an isotope ratio mass spectrometer Delta Plus, Finnigan MAT (Bremen, Germany), connected with a Conflo III-Interface (Finnigan MAT, Bremen, Germany) to an elemental analyzer NA1110 (CE-Instruments, Rodano, Milano, Italy) to determine the ${ }^{15} \mathrm{~N}$ signature $\left(\delta^{15} \mathrm{~N}\right)$ of the sample. $\mathrm{N}_{2}$ was used as reference gas, and was calibrated against the reference substances $\mathrm{N} 1$ and N2 (IAEA, Vienna). Acetanilide was used as internal standard. The Ndfa was calculated as follows:

Ndfa [\%] $=\left(\delta^{15} \mathrm{~N}_{\text {grass }}-\delta^{15} \mathrm{~N}_{\text {legume }}\right) /\left(\delta^{15} \mathrm{~N}_{\text {grass }}-\mathrm{B}\right)$, (Shearer and Kohl, 1986).

$\mathrm{B}$ is the $\delta^{15} \mathrm{~N}$ of a legume grown on an $\mathrm{N}$-free medium, thus receiving all $\mathrm{N}$ from the atmosphere. We used $-1.6 \%$ as a default value, i.e. the mean $\mathrm{B}$ value determined for six common legumes in our latitude (Klatt, 2008). As $\delta^{15} \mathrm{~N}_{\text {grass }}$, mean grass $\delta^{15} \mathrm{~N}$ values per block were used. In 2008, legumes and grasses were sampled indifferently of the species; in 2009, Trifolium repens as legume and Dactylis glomerata as reference plant were sampled to reduce variability due to species-specific differences in $\mathrm{N}$ fixation or assimilation. T. repens was the main legume on the plots, with contributions of Medicago lupulina on one block and minor occurrence of Trifolium pratense. The contribution of $\mathrm{N}$ fixed by legumes to total $\mathrm{N}$ was calculated as follows:

Legume yield $\left[\mathrm{kg} \mathrm{ha}^{-1} \mathrm{a}^{-1}\right]=$ standing biomass $\left[\mathrm{kg} \mathrm{ha}^{-1} \mathrm{a}^{-1}\right] *$ legume yield share $[\%] / 100$, $\mathrm{N}$ content legumes $\left[\mathrm{kg} \mathrm{ha}^{-1} \mathrm{a}^{-1}\right]=$ Legume yield $\left[\mathrm{kg} \mathrm{ha}^{-1} \mathrm{a}^{-1}\right] * \mathrm{~N}$ content $[\%] / 100$, $\mathrm{N}_{\text {fixed }}\left[\mathrm{kg} \mathrm{ha}^{-1} \mathrm{a}^{-1}\right]=\mathrm{N}$ content legumes $\left[\mathrm{kg} \mathrm{ha}^{-1} \mathrm{a}^{-1}\right] * \mathrm{Ndfa}[\%] / 100$,

Contribution of $\mathrm{N}$ fixed by legumes to total $\mathrm{N}[\%]=\mathrm{N}_{\text {fixed }}\left[\mathrm{kg} \mathrm{ha}^{-1} \mathrm{a}^{-1}\right] /$ (standing biomass $[\mathrm{kg}$ $\left.\mathrm{ha}^{-1} \mathrm{a}^{-1}\right] * \mathrm{~N}$ content $\left.[\%] / 100\right) * 100$. 
In paddocks where M. lupulina also occurred, total $\mathrm{N}$ fixed was calculated as the sum of the fixed $\mathrm{N}$ that was determined separately for M. lupulina and T. repens.

All statistics were done with $\mathrm{R}(2.11 .1,2010)$. To test the assumptions for parametric tests, common visual tests like the normal QQ plot (test of normality) and the residuals versus fitted values plot (test of variance homogeneity) were used. Linear mixed model ANOVAs with sward type and grazing animal as fixed factors and block as random factor were performed; for analysis of year effects, repeated measurement ANOVAs based on a linear mixed model were performed. Multiple post hoc comparisons were based on linear models, with block as first factor and the fixed factors following. $P$-values were Bonferroni-adjusted. When the assumptions for parametric tests were not met, non parametric Kruskal-Wallis tests were performed to test for sward effects and grazing animal effects within swards.

Outliers in regressions of $\mathrm{CSH}$ and biomass were identified via standardized residuals (Tabachnick and Fidell, 2010); values equal to or larger than the critical threshold of \pm 3.0 (Beichelt et al., 2003) were excluded from analysis. 


\section{Results}

Pre-grazing biomass did not differ among treatments before the beginning of grazing in the three experimental years (data not shown) and did not differ between sward types during the grazing season (Tab. 1). The post-grazing biomass was significantly smaller in the diverse compared to the grass sward in $2007(P=0.002)$ and when the three experimental years were considered $(P=0.026)$, but was similar between swards in 2008 and 2009 (Tab. 1). The herbage consumption by animals, determined as the yearly differences between post- and pregrazing biomass, was larger in the diverse than in the grass sward in $2007(P=0.012)$, but did not differ between swards in 2008 and 2009. It was larger in 2007 and 2008 compared to 2009 (data not shown).

Table 1: Pre- and post-grazing herbage dry matter $(\mathrm{dm})$ in grass and diverse swards grazed by either cattle (C), sheep (S) or co-grazed by cattle and sheep (CS). Shown are means of three grazing cycles per year; statistics are based on repeated measurement ANOVAs over grazing cycles or years. Significant differences among treatments within sward type are indicated by small letters.

\begin{tabular}{|c|c|c|c|c|c|c|c|c|c|}
\hline \multicolumn{2}{|c|}{ Treatment } & \multicolumn{4}{|c|}{$\begin{array}{l}\text { Pre-grazing herbage mass } \\
\qquad\left(\mathrm{dm} \mathrm{ha} \mathrm{h}^{-1}\right)\end{array}$} & \multicolumn{4}{|c|}{$\begin{array}{l}\text { Post-grazing herbage mass } \\
(\mathrm{t} \mathrm{dm} \mathrm{ha-1)}\end{array}$} \\
\hline Sward type (St) & Grazing $(\mathbf{G})$ & 2007 & 2008 & 2009 & Mean & 2007 & 2008 & 2009 & mean \\
\hline \multirow[t]{3}{*}{ Grass } & $\mathrm{C}$ & 3.43 & 3.81 & 2.63 & 3.29 & 2.16 & $2.39^{\mathrm{b}}$ & 2.06 & 2.20 \\
\hline & CS & 3.44 & 3.68 & 2.65 & 3.25 & 2.17 & $2.26^{\mathrm{ab}}$ & 1.90 & 2.11 \\
\hline & $\mathrm{S}$ & 3.21 & 3.69 & 2.28 & 3.06 & 1.90 & $2.32^{\mathrm{a}}$ & 1.65 & 1.96 \\
\hline \multirow[t]{3}{*}{ Diverse } & $\mathrm{C}$ & $3.00^{\mathrm{a}}$ & 3.36 & 2.28 & 2.88 & 1.63 & 2.32 & 1.60 & 1.85 \\
\hline & CS & $3.18^{\mathrm{a}}$ & 3.45 & 2.55 & 3.06 & 1.56 & 2.25 & 1.84 & 1.88 \\
\hline & $\mathrm{S}$ & $3.74^{\mathrm{b}}$ & 3.67 & 2.61 & 3.34 & 1.93 & 2.51 & 1.94 & 2.13 \\
\hline \multicolumn{10}{|c|}{ ANOVA summary, significance of F-value } \\
\hline & Sward type (St) & ns & ns & ns & ns & 0.002 & ns & ns & 0.026 \\
\hline & Grazing $(\mathrm{G})$ & 0.046 & ns & ns & ns & ns & ns & ns & ns \\
\hline & St x G & 0.013 & ns & ns & ns & 0.040 & ns & 0.035 & ns \\
\hline
\end{tabular}

In the diverse sward, the pre-grazing biomass became significantly larger during the grazing season in 2007 in the sheep- compared to the cattle- and co-grazed paddocks $(P=0.035)$, but was unaffected by grazing treatment in the grass sward in 2007 and in both swards in 2008 and 2009 (Tab. 1). Post-grazing biomass was significantly smaller in sheep- than in cattlegrazed grass paddocks in $2008(P=0.028$, Tab. 1$)$, but was unaffected by grazing treatment. There was a significant interaction between sward and grazing treatment on post-grazing biomass in $2008(P=0.040)$ and $2009(P=0.035)$. There were no consistent effects of grazing treatment on herbage consumption.

The annual pasture productivity was not affected by sward type or by grazing treatment, but was -like the animals' herbage consumption- larger in $2007\left(6.1 \pm 0.6 \mathrm{t} \mathrm{ha}^{-1} \mathrm{a}^{-1}\right)$ and 2008 (6.6 
$\left.\pm 0.5 \mathrm{tha}^{-1} \mathrm{a}^{-1}\right)$ compared to $2009\left(3.8 \pm 0.3 \mathrm{tha}^{-1} \mathrm{a}^{-1}\right.$, means $\pm \mathrm{sd}$, respectively; $\mathrm{P}<0.001$, Tab. 2).

In the grass sward, the proportion of legumes was small $(\leq 2.4 \%)$ until the third grazing cycle in 2008; thereafter, legume yields tended to increase in cattle- and to less extent in sheepgrazed paddocks (differences not significant, Tab. 2). The legume yield differed notably between sward types in 2008, especially during the first two grazing cycles $(P<0.001$, for the third grazing cycle $P=0.067$ ). Legume yield percentages increased from 2008 to 2009 by on average $3 \%$ in the grass sward, but were still larger in the diverse compared to the grass sward, even in 2009 (10 vs. $4 \%$, for the diverse and grass swards, respectively).

Table 2: Annual pasture productivity, legume yield and nitrogen derived by fixation from the atmosphere (Ndfa) in grass and diverse sward types, grazed by either cattle (C), sheep (S) or co-grazed by cattle and sheep (CS), per year or for the three grazing cycles (C1, C2, C3) in 2008. Significant differences among treatments within sward type are indicated by small letters; ns: not significant, statistics of Ndfa were not possible (na) since too many values were missing due to legume proportions being below the threshold of $2.7 \%$.

\begin{tabular}{|c|c|c|c|c|c|c|c|c|c|}
\hline \multirow{2}{*}{$\begin{array}{c}\text { Sward type } \\
\text { Grazing } \\
\text { treatment }\end{array}$} & \multicolumn{3}{|c|}{ Grass } & \multicolumn{3}{|c|}{ Diverse } & \multicolumn{3}{|c|}{$\begin{array}{l}\text { ANOVA summary, Significance of F- } \\
\text { value }\end{array}$} \\
\hline & $\mathbf{C}$ & CS & $\mathbf{S}$ & $\mathbf{C}$ & CS & $\mathbf{S}$ & $\begin{array}{c}\text { Sward type } \\
\text { (St) }\end{array}$ & $\begin{array}{c}\text { Grazing } \\
\text { treatment }(\mathbf{G})\end{array}$ & $\begin{array}{c}\text { St } \mathbf{x} \\
\mathbf{G}\end{array}$ \\
\hline \multicolumn{10}{|c|}{ annual pasture productivity $(\mathrm{t} \mathrm{dm} \mathrm{ha-1})$} \\
\hline 2007 & 5.65 & 5.68 & 5.85 & 5.69 & 6.22 & 7.23 & ns & ns & ns \\
\hline 2008 & 7.08 & 6.99 & 6.72 & 5.73 & 6.4 & 6.74 & ns & $\mathrm{ns}$ & $\mathrm{ns}$ \\
\hline 2009 & 3.74 & 4.13 & 3.59 & 3.45 & 4.04 & 3.78 & ns & ns & ns \\
\hline \multicolumn{10}{|c|}{ legume yield $(\%)$} \\
\hline $2008, \mathrm{C} 1$ & 0.33 & 0.01 & 2.40 & $24.55^{\mathrm{b}}$ & $5.60^{\mathrm{ab}}$ & $1.43^{\mathrm{a}}$ & $<0.001$ & $\mathrm{~ns}$ & 0.022 \\
\hline $2008, \mathrm{C} 2$ & 1.61 & 0.07 & 0.16 & $15.90^{\mathrm{b}}$ & $3.47^{\mathrm{ab}}$ & $0.38^{\mathrm{a}}$ & $<0.001$ & 0.002 & 0.023 \\
\hline $2008, \mathrm{C} 3$ & 6.30 & 0.30 & 1.55 & $11.51^{\mathrm{b}}$ & $4.22^{\mathrm{ab}}$ & $0.57^{\mathrm{a}}$ & ns & 0.007 & ns \\
\hline \multicolumn{10}{|c|}{ nitrogen derived from the atmosphere $(\%)$} \\
\hline 2008, C1 & na & na & 44.33 & 66.07 & 67.03 & 58.78 & na & na & na \\
\hline $2008, \mathrm{C} 2$ & na & na & na & 80.83 & 83.66 & na & na & na & na \\
\hline $2008, \mathrm{C} 3$ & 92.51 & na & 18.95 & 67.40 & 84.72 & na & na & na & na \\
\hline
\end{tabular}

Within the diverse sward, legume yields in 2008 and in the first cycle in 2009 were significantly larger in cattle- compared to sheep-grazed paddocks, with co-grazed paddocks being intermediate $(P=0.032, P=0.011$ and $P=0.021$ for the three grazing cycles in 2008 and $P=0.027$ for the first grazing cycle in 2009, respectively; data not shown for 2009); a trend to this pattern persisted in the second and third grazing cycle in 2009. The Ndfa was similar among grazing treatments in the diverse sward, but much lower in the sheep-than in the cattle-grazed grass paddocks at the third cycle in 2008; however due to too many missing values no statistics of treatment effects on Ndfa could be performed. 
The sward type had effects on several herbage quality characteristics measured before the respective grazing events but these were not consistently found over all grazing cycles and years. In various cases, the $\mathrm{CP}$ content was larger in the diverse compared to the grass sward, whereas both the WSC and the ADF content were smaller. In the third grazing cycle in 2008, for example, the CP content was by $30 \%$ larger in the diverse sward $(P=0.019)$ and the WSC and ADF contents by 8 and $10 \%$ smaller than in the grass sward $(P=0.034$ and $P=$ 0.017, for WSC and ADF, respectively; Tab. 3). The ME was larger in the diverse compared to the grass sward in $2009(P=0.027)$ if grazing cycle was considered as repeated measurement factor. Grazing treatment had no consistent effect on the measured herbage quality characteristics in the grass or diverse sward.

Table 3: Metabolizable energy, crude protein, acid detergent fiber and water soluble carbohydrate content of the herbage in cattle and sheep mono- and co-grazed (C, S and CS respectively) grass and diverse paddocks in 2008. Shown are means of three grazing cycles (C1, C2, C3) and the ANOVA statistics (ns: not significant). Significant differences among treatments within sward types are indicated by small letters.

\begin{tabular}{|c|c|c|c|c|c|c|c|c|c|}
\hline & \multicolumn{3}{|c|}{ Grass } & \multicolumn{3}{|c|}{ Diverse } & \multicolumn{3}{|c|}{$\begin{array}{c}\text { ANOVA summary, Significance } \\
\text { of F-value }\end{array}$} \\
\hline & $\mathbf{C}$ & CS & $\mathbf{S}$ & $\mathbf{C}$ & CS & $\mathbf{S}$ & $\begin{array}{c}\text { Sward } \\
\text { type } \\
\text { (St) } \\
\end{array}$ & $\begin{array}{c}\text { Grazing } \\
\text { treatment } \\
\text { (G) }\end{array}$ & St $\times$ G \\
\hline \multicolumn{10}{|c|}{ metabolizable energy $\left(\mathrm{MJ} \mathrm{kg}^{-1}\right)$} \\
\hline $\mathrm{C} 1$ & 10.5 & 10.4 & 10.4 & 10.5 & 10.6 & 10.5 & $\mathrm{~ns}$ & $\mathrm{~ns}$ & ns \\
\hline $\mathrm{C} 2$ & 9.4 & 9.2 & 9.0 & 9.8 & 9.4 & 9.4 & $\mathrm{~ns}$ & ns & ns \\
\hline $\mathrm{C} 3$ & 8.9 & 9.8 & 9.8 & $9.9^{\mathrm{ab}}$ & $10.1^{\mathrm{b}}$ & $8.9^{\mathrm{a}}$ & $\mathrm{ns}$ & $\mathrm{ns}$ & 0.022 \\
\hline \multicolumn{10}{|c|}{ crude protein $\left(\mathrm{g} \mathrm{kg}^{-1}\right)$} \\
\hline $\mathrm{C} 1$ & 99.9 & 124.8 & 109.3 & 114.3 & 115.8 & 99.9 & ns & $\mathrm{ns}$ & $\mathrm{ns}$ \\
\hline $\mathrm{C} 2$ & 90.3 & 92.1 & 119.6 & 110.5 & 87.2 & 90.3 & ns & ns & ns \\
\hline $\mathrm{C} 3$ & 86.5 & 98.3 & 94.5 & 119.7 & 136.7 & 86.5 & 0.019 & ns & ns \\
\hline \multicolumn{10}{|c|}{ acid detergent fiber $\left(\mathrm{g} \mathrm{kg}^{-1}\right)$} \\
\hline $\mathrm{C} 1$ & 297.6 & 289.8 & 305.2 & 291.7 & 288.9 & 297.6 & $\mathrm{~ns}$ & ns & $\mathrm{ns}$ \\
\hline $\mathrm{C} 2$ & 316.3 & 331.6 & 331.3 & 298.3 & 335.4 & 316.3 & $\mathrm{~ns}$ & ns & $\mathrm{ns}$ \\
\hline $\mathrm{C} 3$ & $345.0^{\mathrm{b}}$ & $281.6^{\mathrm{a}}$ & $296.0^{\mathrm{ab}}$ & 279.8 & 256.8 & 345.0 & 0.017 & 0.020 & ns \\
\hline \multicolumn{10}{|c|}{ water soluble carbohydrate $\left(\mathrm{g} \mathrm{kg}^{-1}\right)$} \\
\hline $\mathrm{C} 1$ & 188.6 & 148.7 & 156.9 & 159.7 & 170.1 & 188.6 & $\mathrm{~ns}$ & $\mathrm{~ns}$ & $\mathrm{~ns}$ \\
\hline $\mathrm{C} 2$ & 121.1 & 119.5 & 109.5 & 127.1 & 136.0 & 121.1 & $\mathrm{~ns}$ & $\mathrm{~ns}$ & $\mathrm{~ns}$ \\
\hline $\mathrm{C} 3$ & 84.1 & 137.7 & 132.2 & 95.0 & 116.3 & 84.1 & 0.034 & 0.022 & $\mathrm{~ns}$ \\
\hline
\end{tabular}




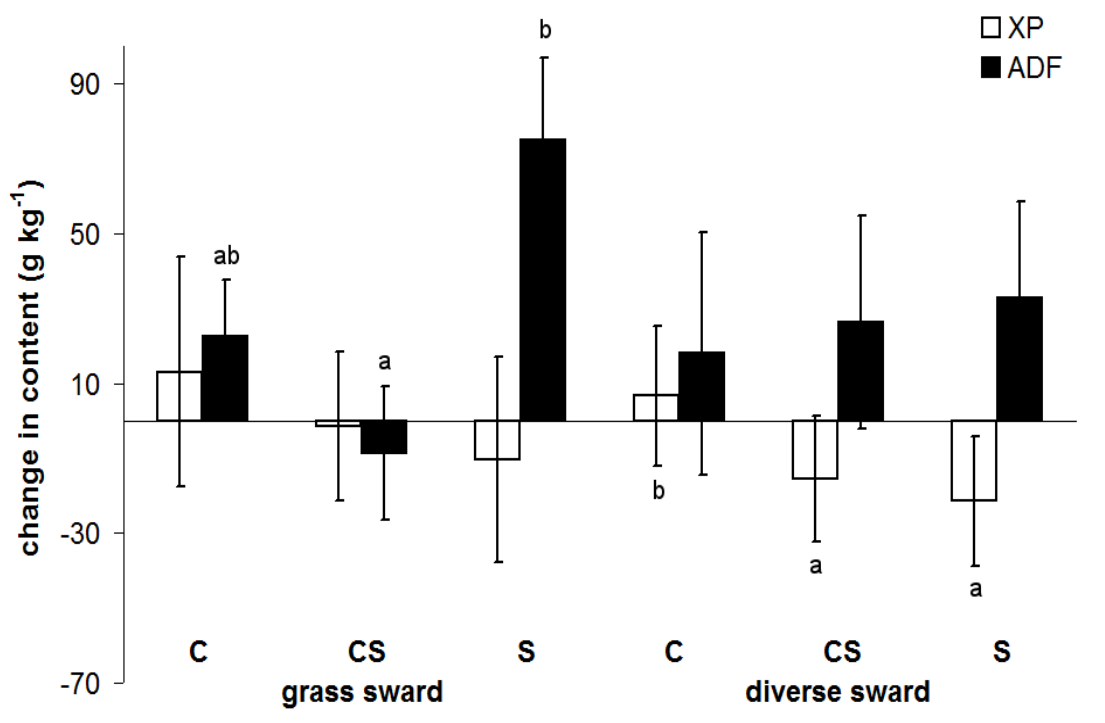

Figure 1: Changes in the content $\left(\mathrm{g} \mathrm{kg}^{-1}\right)$ of crude protein and acid detergent fiber (CP and ADF, respectively) before and after grazing in herbage of cattle and sheep mono- and co-grazed (C, S and CS, respectively) grass and diverse paddocks before and after grazing (third grazing cycle, 2007). Differences among treatments within sward types are indicated by small letters $(P \leq 0.01$ for $\mathrm{CP}$ and $P$ $\leq 0.05$ for $\mathrm{ADF})$.

In 2007, herbage quality characteristics were also analyzed after grazing. The ME of the herbage did not differ between pre- and post-grazing in any grazing cycle or treatment (data not shown). In the diverse sward, the ADF content of the herbage post-grazing had increased to a similar extent in all treatments (Fig. 1). In the grass sward, the ADF content notably increased in the sheep paddocks during grazing. In co- and cattle-grazed paddocks $(P=0.016$, Fig. 1) it decreased or increased to a lesser extent. In the diverse sward, the CP content was smaller in co- and sheep-grazed paddocks after grazing than before (by 16 and $21 \mathrm{~g} \mathrm{~kg}^{-1}$, respectively), but increased in the cattle-grazed treatment (by $9 \mathrm{~g} \mathrm{~kg}^{-1} ; P=0.009$ ). No difference was found among treatments with regard to the $\mathrm{CP}$ and ADF content of the herbage before and after grazing.

The annual $\mathrm{N}$ yield in the biomass was similar between sward types in 2008 and 2009. Grazing treatment did not affect the annual N yield with exception of the grass sward in 2009, when the annual $\mathrm{N}$ yield was significantly higher in the cattle- compared to the sheep- and cograzed treatments $(P=0.015$, Fig. 2$)$, which was also found in tendency in 2008 . In the diverse swards, the annual $\mathrm{N}$ yield did not differ significantly among grazing treatments in 2008 or 2009 . The contribution of fixed $\mathrm{N}$ to the total $\mathrm{N}$ yield in the biomass was significantly larger in cattle- than in sheep-grazed paddocks in the diverse sward in $2009(P=0.030$; Fig. 2) and in tendency in $2008(P=0.058$, data not shown). 


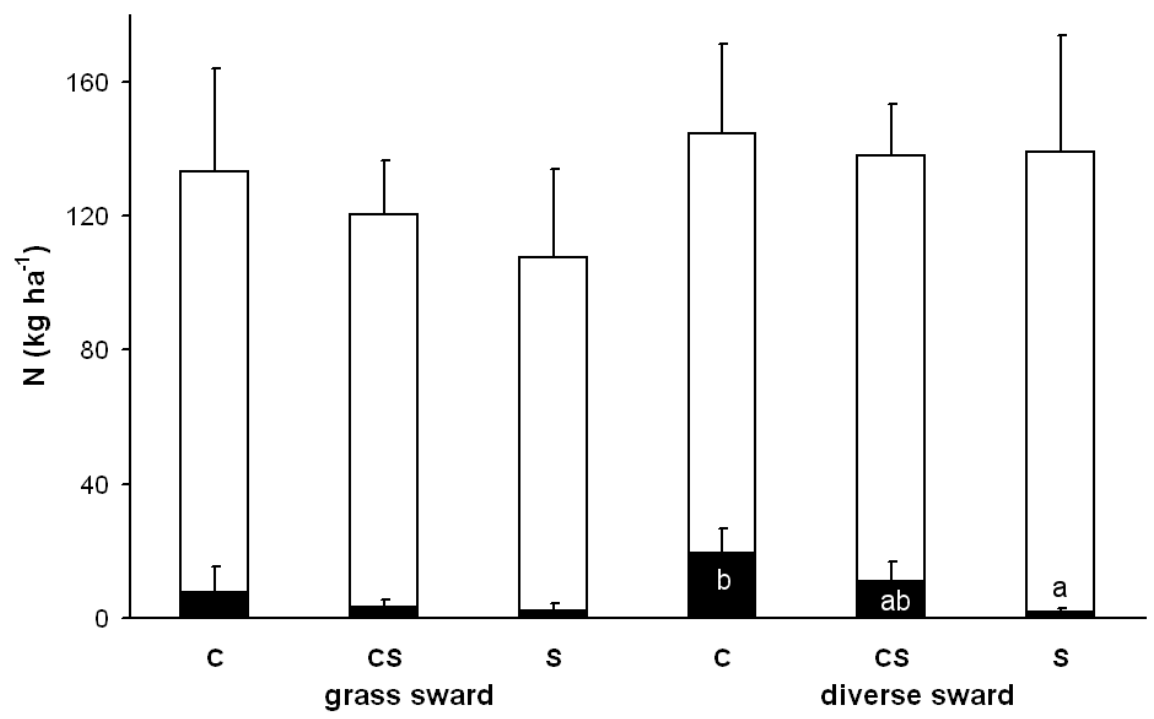

Figure 2: Annual nitrogen yield and the respective fixed $\mathrm{N}$ proportion $\left(\mathrm{kg} \mathrm{ha}^{-1} \mathrm{a}^{-1}\right.$, summed over the three grazing cycles) in cattle and sheep mono- and co-grazed (C, S and CS respectively) grass and diverse swards in 2009. Significant differences $(P \leq 0.05)$ among treatments within sward type are indicated by small letters within (fixed $\mathrm{N}$ ) or above columns (nitrogen yield). 


\section{Discussion}

In this study, we investigated the effects of sward diversity in interaction with mono- and cograzing cattle and sheep on productivity and quality of herbage in a semi-natural permanent grassland. In the following, we will discuss the effects of sward and grazing treatments with respect to productivity first and then focus on herbage quality.

Herbage productivity

Generally, the annual pasture productivity, i.e. the sum of herbage consumption and vegetation growth, lay within the range found for unfertilized Lolio-Cynosuretum meadows (Hejcman et al., 2010) and at the lower end of unfertilised lowland semi-natural grasslands of different communities (Tallowin and Jefferson, 1999). Annual pasture productivity showed a high annual variation with notably smaller yields in 2009 compared to 2007 and 2008 (Tab. 2). Precipitation rates were lower in 2008 and 2009 (417 and $408 \mathrm{~mm}$, vs. $689 \mathrm{~mm}$ in 2007), leading to less grazing days in both years $\left(55\right.$ and $50 \mathrm{~d} \mathrm{ha}^{-1}$ in 2008 and $2009 \mathrm{vs.} 63 \mathrm{~d} \mathrm{ha}^{-1}$ in 2007). However, the more severe drought in August 2009 (37 mm) compared to 2008 (72 $\mathrm{mm}$ ) apparently resulted in larger effects on herbage growth rates and productivity. Generally, differences among individuals and species of grazing animals regarding forage intake rates might also occur as a result of differences in the physiological weight of animals, even though attention was paid to assign animals of similar live weight in equal numbers to the pastures.

Contrary to our hypothesis, biomass production in the diverse sward was not larger than in the grass sward. Productivity is thought to be connected to plant species number, functional group richness, positive species interactions, complementary resource use, and species identity effects (Dodd et al., 2004; Hooper et al., 2005; van Ruijven and Berendse, 2003). In our study, plant species number was significantly larger in the diverse compared to the grass sward in 2007 and 2008, but increased in the grass sward to similar species numbers in 2009. Significant differences in functional group proportions between sward types persisted and even increased, related to an increase in forb abundance between 2007 and 2009 by $26 \%$ in the diverse sward. Therefore, either decreasing differences in productivity would be expected if plant species numbers were a good explanation or increasing differences if functional group proportions were a good explanation for the productivity of sward types from 2007 to 2009 . However, neither annual pasture productivity nor pre-grazing herbage mass or herbage intake was related to plant species number or functional group proportions. In the grass sward, plant species numbers were relatively large (on average 9, 12 and 15 or 7, 10 and 10 species, based on 9 or $1 \mathrm{~m}^{2}$ plots, from 2007 to 2009 , respectively) compared to those in low-diversity treatments in experimental studies. Therefore, positive species interactions and 
complementary resource use might have been similarly important in the grass and diverse swards -irrespective of whether species were monocots or dicots. In both sward types, Lolium perenne and the high yielding species Dactylis glomerata (Pontes et al., 2007) accounted for the main yield proportions. Together, both species made up 37 or $32 \%$ in the diverse sward in 2008 and 2009, respectively, and $38 \%$ in the grass sward in both years. The equally large proportion of these plant species in both swards might have contributed to the similar productivity of the two sward types.

Our results are in accordance with findings on herbage production (Tracy and Faulkner, 2006) and intake (Soder et al., 2006) being unaffected by the number of plant species, even though differences in plant species numbers in these experimental grasslands (three, five and eight, or two, three, six and nine plant species, respectively) were much larger than in our study. The finding of NDF or dry matter digestibility (here: ME) being related to herbage consumption (Soder et al., 2006) was not confirmed by our results. This was possibly due to similar palatability of the herbage in both swards as a result of larger WSC in the grass but larger CP in the diverse sward. The stability of dry matter provision under variable environmental conditions that was sometimes found to be larger with increasing species richness (Deak et al., 2009), was (determined by the coefficient of variation of the annual pasture productivity; data not shown) unaffected by sward type in our study. Our results support the finding by Kahmen et al. (2005) that for permanent grassland, plant diversity per se is not a strong predictor of productivity.

The expectation of a similar productivity among grazing treatments in the diverse sward was confirmed (Tab. 2). Grazing treatment had in most cases a significant effect on the legume abundance, with larger legume reduction in sheep- compared to cattle- and co-grazed paddocks (Tab. 2), as also found by Nolan et al. (2001). The contribution of fixation by legumes to total $\mathrm{N}$ was consequently notably smaller in sheep- compared to cattle- grazed paddocks in $2008(P=0.059)$ and $2009(P=0.030)$.

In the grass sward, our expectation of higher productivity in sheep- compared to cattle- and co-grazed treatments due to generally minor relevance of fixed $\mathrm{N}$ in this sward and the more homogeneous excreta distribution by sheep could not be confirmed. Despite the negligible effect of legumes, the productivity was similar among grazing treatments. This is in contrast to findings of higher herbage accumulation in sheep-grazed paddocks compared to paddocks co-grazed by cattle and sheep following cattle grazing (Murphy et al., 1995). Our underlying assumption of larger $\mathrm{N}$ availability for biomass production in the sheep- compared to the cattle-grazed grass paddocks was not confirmed: Contrary to our expectation, $\mathrm{N}$ yields in the 
biomass were signficantly larger in cattle-grazed compared to the other treatments. This might be due to in tendency smaller changes in the $\mathrm{CP}$ content of the herbage during grazing in cattle-grazed paddocks (Fig. 1). Also, a more efficient use of excreta $\mathrm{N}$ in the cattle-grazed treatment, caused by a higher abundance of plant species that use $\mathrm{N}$ more efficiently than others, as found for Dactylis glomerata (Austin and Austin, 1980), is possible.

As expected, the amount of fixed $\mathrm{N}$ was significantly smaller in sheep- compared to co- and cattle-grazed diverse paddocks in 2009. However, as a result of too many sheep-grazed paddocks being below the sampling threshold for Ndfa measurements, it was not possible to assess in how far the grazing treatment affected the $\mathrm{N}$ fixation rate. The finding of smaller amounts of fixed $\mathrm{N}$ in sheep paddocks may therefore, assuming no or negligible treatment effects on Ndfa, be the mere effect of sheep grazing legumes more selectively than cattle (Nolan et al., 2001). Similar productivity among grazing treatments within the grass sward does not point to grazing animal specific effects of excreta distribution on productivity. However, the nutrient availability in the cattle-grazed paddocks may have been sufficient for plant growth in these first years of different grazing Grazer effects on productivity may be detectable after a longer time of different management.

\section{Herbage quality}

The expectation of higher herbage quality in the diverse compared to the grass sward could be confirmed. In the diverse sward, an additional $\mathrm{N}$ supply by legumes was connected to larger CP and energy content, confirming findings in other studies (Hofmann and Isselstein, 2005; Pontes et al., 2007). Larger proportions of tall growing grasses and correspondingly larger lignin contents were related to relatively large ADF values and smaller herbage quality in the grass sward. The WSC content, however, was much larger in the grass than in the diverse sward. Both the diverse and the grass-dominated swards supplied the animals with CP contents in the typical range for grassland with two to three utilisations (Döhler, 2009) and lay in the medium range for unfertilised semi-natural lowland grasslands of different plant communities (Tallowin and Jefferson, 1999).

Contrary to our hypothesis, co-grazing did not result in higher herbage quality compared to mono-grazing. However, we did find significant grazing animal effects on herbage composition pre- and post-grazing, confirming our hypothesis of grazing animal effects on herbage quality: In the diverse sward, the CP content decreased significantly in herbage of coand sheep- relative to cattle-grazed paddocks. This is in accordance with findings of a diet larger in $\mathrm{N}$ in sheep than in cattle (Wilson, 1976) attributable to larger herbage selectivity (Grant et al., 1985; Grant et al., 1987) and stronger reduction of legumes by sheep (Abaye et 
al., 1994; Wilson, 1976). In the grass sward, the ADF content increased significantly during grazing in sheep- relative to cattle- and co-grazed paddocks. This coincides with our finding of larger increases of the proportion of Dactylis glomerata in sheep- compared to co- and cattle-grazed paddocks (to 32 vs. 17 and $15 \%$, respectively) from 2008 to 2009. It was also observed that the proportion of $D$. glomerata increased with time within the respective grazing season. This can be attributed to less feeding by sheep on fibrous plant components like reproductive grass stems (Abaye et al., 1994; Grant et al., 1987).

\section{Conclusion}

In contrast to results from experimental grasslands, we did not find consistently larger productivity in more diverse pastures. Smallest plant diversity levels in experimental grasslands are usually far below the nine or seven (in 9 or $1 \mathrm{~m}^{2}$ plots) species of our lowdiversity grass sward. Furthermore, species identity and positive species interactions may have been similarly important for biomass production in both sward types of our study. Generally, the comparison of randomly assembled plant communities with permanent grassland seems difficult and findings might not be transferable between these systems. Permanent grassland makes up $40 \%$ of the terrestrial area (White et al., 2000), contributes to the livelihoods of over 800 million people, many of which are smallholder farmers (Reynolds et al., 2005), and is habitat to a broad variety of plant and animal species (WallisDeVries et al., 2002). Therefore, it is of great importance to understand the functions diversity might have for the achievement of productivity and other agronomic goals in these systems.

We found a higher herbage quality in diverse compared to grass-dominated swards and significant post-grazing effects of mono-grazing cattle and sheep in both swards. No positive co-grazing effects on the analysed herbage quality characteristics were detectable within the time period of three years. However, such an effect -related to significant changes in the vegetation composition as a result of differential grazing- seems likely in the long term. 


\section{References}

Abaye, A.O., V.G. Allen, and J.P. Fontenot. 1994. Influence of grazing cattle and sheep together and separately on animal performance and forage quality. J. Anim Sci. 72:1013-1022.

Amarger, N., A. Mariotti, F. Mariotti, J. Durr, C. Bourguignon, and B. Lagacherie. 1979. Estimate of symbiotically fixed nitrogen in field grown soybeans using variations in ${ }^{15} \mathrm{~N}$ natural abundance. Plant and Soil 52:269-280.

Austin, M.P., and B.O. Austin. 1980. Behaviour of experimental plant communities along a nutrient gradient. Journal of Ecology 68:891-918.

Bakker, J.P., J. Leeuw, and S.E. Wieren. 1984. Micro-patterns in grassland vegetation created and sustained by sheep-grazing. Plant Ecology 55:153-161.

Beichelt, F.E., S. Cheng, G. Christoph, C.L. Jennings, B.D. Macpherson, D.C. Montgomery, R.H. Myers, R. Pincus, T.J. Robinson, J.R. Simpson, G.G. Vining, and J.W. Wisnowsky. 2003. Taschenbuch der Stochastik. Wahrscheinlichkeitstheorie, Stochastische Prozesse, Mathematische Statistik. 1 ed. Teubner Verlag, Wiesbaden.

Bullock, J.M., R.F. Pywell, and K.J. Walker. 2007. Long-term enhancement of agricultural production by restoration of biodiversity. Journal of Applied Ecology 44:6-12.

Castle, M.E. 1976. A simple disc instrument for estimating herbage yield. Journal of the British Grassland Society 31: 37-40.

Correll, O., J. Isselstein, and V. Pavlu. 2003. Studying spatial and temporal dynamics of sward structure at low stocking densities: the use of an extended rising-plate-meter method. Grass and Forage Science 58:450-454.

de Bello, F., S. Lavorel, S. Díaz, R. Harrington, J. Cornelissen, R. Bardgett, M. Berg, P. Cipriotti, C. Feld, D. Hering, P. Martins da Silva, S. Potts, L. Sandin, J. Sousa, J. Storkey, D. Wardle, and P. Harrison. 2010. Towards an assessment of multiple ecosystem processes and services via functional traits. Biodiversity and Conservation 19:2873-2893.

Deak, A., M.H. Hall, and M.A. Sanderson. 2009. Grazing schedule effect on forage production and nutritive value of diverse forage mixtures. Agronomy Journal 101:408-414.

Dewhurst, R.J., L. Delaby, A. Moloney, T. Boland, and E. Lewis. 2009. Nutritive value of forage legumes used for grazing and silage. Irish Journal of Agricultural and Food Research 48:167187.

Dodd, M.B., D.J. Barker, and M.E. Wedderburn. 2004. Plant diversity effects on herbage production and compositional changes in New Zealand hill country pastures. Grass and Forage Science 59:29-40.

Döhler, H. 2009. Faustzahlen für die Landwirtschaft. 14 ed. Kuratorium für Technik und Bauwesen in der Landwirtschaft e. V. (KTBL). Darmstadt, p. 661.

Dudzinski, M., and G. Arnold. 1973. Comparisons of diets of sheep and cattle grazing together on sown pastures on the Southern Tablelands of New South Wales by principal components analysis. Australian Journal of Agricultural Research 24:899-912.

Dumont, B., P. D'hour, and M. Petit. 1995. The usefulness of grazing tests for studying the ability of sheep and cattle to exploit reproductive patches of pastures. Applied Animal Behaviour Science 45:79-88.

Forbes, T.D.A., and J. Hodgson. 1985. The reaction of grazing sheep and cattle to the presence of dung from the same or the other species. Grass and Forage Science 40:177-182.

GfE. Ausschuss für Bedarfsnormen der Gesellschaft für Ernährungsphysiologie. 2008. New equations for predicting metabolisable energy of grass and maize products for ruminants. Proceedings of the Society of Nutrition Physiology 17:191 - 198.

Grant, S.A., D.E. Suckling, H.K. Smith, L. Torvell, T.D.A. Forbes, and J. Hodgson. 1985. Comparative studies of diet selection by sheep and cattle: The hill grasslands. Journal of Ecology 73:987-1004.

Grant, S.A., L. Torvell, H.K. Smith, D.E. Suckling, T.D.A. Forbes, and J. Hodgson. 1987. Comparative studies of diet selection by sheep and cattle: Blanket bog and heather moor. Journal of Ecology 75:947-960.

Hector, A., B. Schmid, C. Beierkuhnlein, M.C. Caldeira, M. Diemer, P.G. Dimitrakopoulos, J.A. Finn, H. Freitas, P.S. Giller, J. Good, R. Harris, P. Högberg, K. Huss-Danell, J. Joshi, A. 
Jumpponen, C. Körner, P.W. Leadley, M. Loreau, A. Minns, C.P.H. Mulder, G. O'Donovan, S.J. Otway, J.S. Pereira, A. Prinz, D.J. Read, M. Scherer-Lorenzen, E.-D. Schulze, A.-S.D. Siamantziouras, E.M. Spehn, A.C. Terry, A.Y. Troumbis, F.I. Woodward, S. Yachi, and J.H. Lawton. 1999. Plant diversity and productivity experiments in European grasslands. Science 286:1123-1127.

Hejcman, M., J. Schellberg, and V. Pavlu. 2010. Long-term effects of cutting frequency and liming on soil chemical properties, biomass production and plant species composition of LolioCynosuretum grassland after the cessation of fertilizer application. Applied Vegetation Science 13:257-269.

Hofmann, M., and J. Isselstein. 2005. Species enrichment in an agriculturally improved grassland and its effects on botanical composition, yield and forage quality. Grass and Forage Science 60:136-145.

Hooper, D.U., and P.M. Vitousek. 1998. Effects of plant composition and diversity on nutrient cycling. Ecological Monographs 68:121-149.

Kahmen, A., J. Perner, V. Audorff, W. Weisser, and N. Buchmann. 2005. Effects of plant diversity, community composition and environmental parameters on productivity in montane European grasslands. Oecologia 142:606-615.

Kesting, S., N. Wrage, and J. Isselstein. 2009. Herbage mass and nutritive value of herbage of extensively managed temperate grasslands along a gradient of shrub encroachment. Grass and Forage Science 64:246-254.

Klapp, E., and A. Stählin. 1936. Standorte, Pflanzengesellschaften und Leistung des Grünlandes. Ulmer, Stuttgart.

Klatt, S. 2008. Der Beitrag heimischer Leguminosen zur Stickstoffversorgung artenreicher Wiesen im westlichen Hunsrück (Rheinland-Pfalz). Monography, Trier, Cuvillier Verlag Goettingen.

Ledgard, S.F., K.W. Steele, and W.H.M. Saunders. 1982. Effects of urine and its major components on pasture properties. New Zealand Journal of Agricultural Research 25:61-68.

Milne, J.A. 1991. Diet selection by grazing animals. Proceedings of the Nutrition Society 50:77-85.

Murphy, W.M., A.D.M. Barreto, and J.P. Silman. 1995. Sward dynamics of a smooth-stalked meadowgrass dominant white clover sward rotationally grazed by cattle and/or sheep. Grass and Forage Science 50:183-190.

Nolan, T., J. Connolly, and M. Wachendorf. 2001. Mixed grazing and climatic determinants of white clover (Trifolium repens L.) content in a permanent pasture. Annals of Botany 88:713-724.

Pontes, L.S., P. Carrère, D. Andueza, F. Louault, and J.F. Soussana. 2007. Seasonal productivity and nutritive value of temperate grasses found in semi-natural pastures in Europe: responses to cutting frequency and N supply. Grass and Forage Science 62:485-496.

R. 2.11.1, 2010. The R Foundation for Statistical Computing.

Reynolds, S.G., C. Batello, S. Baas, and S. Mack. 2005. Grassland and forage to improve livelihoods and reduce poverty, p. 323-338, In D. A. McGilloway, ed. Grassland-A global resource. Wageningen Academic Publisher, Wageningen.

Richards, C.R., G.F.W. Haenlein, M.C. Calhoun, J.D. Connolly, and H.G. Weaver. 1962. Date of cut vs. the combination of crude fiber and crude protein as estimators of forage quality. Journal of Animal Science 21:844-847.

Rook, A.J., and J.R.B. Tallowin. 2003. Grazing and pasture management for biodiversity benefit. Animal Research 52:181-189.

Rook, A.J., B. Dumont, J. Isselstein, K. Osoro, M.F. WallisDeVries, G. Parente, and J. Mills. 2004. Matching type of livestock to desired biodiversity outcomes in pastures - a review. Biological Conservation 119:137-150.

Scherer-Lorenzen, M., C. Palmborg, A. Prinz, and E.-D. Schulze. 2003. The role of plant diversity and composition for nitrate leaching in grasslands. Ecology 84:1539-1552.

Shearer, G., and D.H. Kohl. 1986. $\mathrm{N}_{2}$ fixation in field settings: estimations based on natural ${ }^{15} \mathrm{~N}$ abundance. Australian Journal of Plant Physiology 13:699-756.

Soder, K.J., M.A. Sanderson, J.L. Stack, and L.D. Muller. 2006. Intake and performance of lactating cows grazing diverse forage mixtures. Journal of Dairy Science 89:2158-2167.

Tabachnick, B.G., and L.S. Fidell. 2010. Using Multivariate Statistics. 5th ed. Boston, Massachusetts: Pearson Education. 
Tallowin, J.R.B., and R.G. Jefferson. 1999. Hay production from lowland semi-natural grasslands: a review of implications for ruminant livestock systems. Grass and Forage Science 54:99-115.

Thomas, D.T., J.T.B. Milton, C.K. Revell, M.A. Ewing, R.A. Dynes, K. Murray, and D.R. Lindsay. 2010. Preference of sheep among annual legumes is more closely related to plant nutritive characteristics as plants mature. Animal Production Science 50:114-123.

Thompson, K., A.P. Askew, J.P. Grime, N.P. Dunnett, and A.J. Willis. 2005. Biodiversity, ecosystem function and plant traits in mature and immature plant communities. Functional Ecology 19:355-358.

Tilman, D. 1997. Community invasibility, recruitment limitation, and grassland biodiversity. Ecology 78:81-92.

Tilman, D., and J.A. Downing. 1994. Biodiversity and stability in grasslands. Nature 367:363-365.

Tracy, B.F., and D.B. Faulkner. 2006. Pasture and cattle responses in rotationally stocked grazing systems sown with differing levels of species richness. Crop Science 46:2062-2068.

van Groenigen, J.W., P.J. Kuikman, W.J.M. de Groot, and G.L. Velthof. 2005. Nitrous oxide emission from urine-treated soil as influenced by urine composition and soil physical conditions. Soil Biology and Biochemistry 37:463-473.

van Ruijven, J., and F. Berendse. 2005. Diversity-productivity relationships: Initial effects, long-term patterns, and underlying mechanisms. Proceedings of the National Academy of Sciences of the United States of America 102:695-700.

Vinther, F.P. 1998. Biological nitrogen fixation in grass-clover affected by animal excreta. Plant and Soil 203:207-215.

Wallis de Vries, M.F., and C. Daleboudt. 1994. Foraging strategy of cattle in patchy grassland. Oecologia 100:98-106.

WallisDeVries, M.F., P. Poschlod, and J.H. Willems. 2002. Challenges for the conservation of calcareous grasslands in northwestern Europe: integrating the requirements of flora and fauna. Biological Conservation 104:265-273.

White, R., S. Murray, and M. Rohweder. 2000. Pilot analysis of gloabal ecosystems: grassland ecosystems. World Resources Institute, Washington DC.

Wilson, A. 1976. Comparison of sheep and cattle grazing on a semiarid grassland. Australian Journal of Agricultural Research 27:155-162.

Wright, I.A., J.R. Jones, and A.J. Parsons. 2001. Effects of grazing by sheep or cattle on sward structure and subsequent performance of weaned lambs. Grass and Forage Science 56:138150.

Zak, D.R., W.E. Holmes, D.C. White, A.D. Peacock, and D. Tilman. 2003. Plant diversity, soil microbial communities, and ecosystem function: are there any links? Ecology 84:2042-2050. 
Chapter III:

Productivity and nutrient use in grassland of differing plant species composition and fertilisation

Seither M., Wrage N., Isselstein J. 


\section{Abstract}

In this study, effects of vegetation composition and nitrogen $(\mathrm{N})$ or phosphorus $(\mathrm{P})$ fertilisation on the productivity and nutrient use of a semi-natural grassland were investigated. Two swards were compared, a natural moderately species-rich Lolio-Cynosuretum ('diverse sward': comprising grasses, forbs and legumes) and its grass-dominated counterpart ('grass sward'), achieved by herbicide application. In two successive years, we measured N, P and potassium $(\mathrm{K})$ uptake and biomass production in both swards without fertiliser addition $(\mathrm{C}$ : Control) or with a single application of $\mathrm{N}$ or $\mathrm{P}$ in two levels each (N1: $50 \mathrm{~kg} \mathrm{~N} \mathrm{ha}^{-1}, \mathrm{~N} 2: 500$ $\left.\mathrm{kg} \mathrm{ha}^{-1}, \mathrm{P} 1: 20 \mathrm{~kg} \mathrm{ha}^{-1}, \mathrm{P} 2: 100 \mathrm{~kg} \mathrm{ha}^{-1}\right)$. The $\mathrm{N}$ fixation by legumes and the abundance of arbuscular mycorrhizal fungi (AMF) structures -as affected by the experimental treatmentswere also examined.

The total nutrient use and productivity were similar between diverse and grass sward. The productivity was increased by the $\mathrm{N} 2$ fertilisation in both swards. The accumulated biomass production over all harvests, however, did not differ significantly among treatments across swards, except for the grass N2 that achieved significantly higher biomass than the diverse control. Legumes played a minor role for the $\mathrm{N}$ supply in the diverse sward due to their small abundances, which is likely to be a combined effect of low management intensity, sufficient $\mathrm{N}$ availability and low precipitation rates. Nutrient uptakes were similar between swards and were strongly related to biomass production. The $\mathrm{N}$ concentration was significantly higher in the $\mathrm{N} 2$ fertilisation treatments of both sward types.

The abundance of AMF structures was unaffected by fertilisation. In some cases, hints to higher density of extraradical hyphae, suggesting increased AMF functioning, were found under conditions of limited $\mathrm{P}$ availability, in the diverse compared to the grass sward or with increasing plant species richness. Our results, however, were not consistent for sampling dates or sward types, possibly due to the multitude of factors determining the AMF community composition and abundance.

In our study, effects of sward composition on nutrient use or biomass production related to plant species complementarities could not be detected. We suggest that in the low-diversity treatment, relatively high plant species numbers $\left(7.9 \pm 2.1\right.$ species per $\left.2.5 \mathrm{~m}^{2}\right)$ that were similar to those of the diverse sward, and generally large nutrient availability due to former grazing led to comparable results for grass and diverse swards.

Keywords: nitrogen, phosphorus, arbuscular mycorrhizal fungi, legumes, diversity 


\section{Introduction}

In the last decades, the interest in sustainable use of agricultural land increased. Sustainable grassland management includes adapted use of fertilisers to avoid nutrient losses and may be enhanced by increased nutrient use of the vegetation. Plant species diversity is often seen as a potential means for complementary resource use (Hooper and Vitousek, 1998; Reich et al., 2004), related to facilitative species interactions and niche differentiation (Reich et al., 2004; Sanderson et al., 2004), resulting in enhanced grassland productivity (Bullock et al., 2001; Tilman et al., 1997). Site factors, vegetation composition and functional group identity may affect the nutrient content (Pan et al., 2010) and productivity of the vegetation. Therefore, plant communities may differ in the nutrient content of the aboveground biomass. For example, the presence of $\mathrm{N}$ fixing legumes may decrease competition for $\mathrm{N}$ and increase productivity (Weigelt et al., 2009).

Arbuscular mycorrizal fungi (AMF) can also increase plant biomass production (van der Heijden et al., 1998). AMF enhance the availability of plant nutrients, especially of those immobile in the soil, like $\mathrm{P}$, by extraradical hyphae attached to the roots that extend the plant exploitable soil volume (Jakobsen et al., 1992). Extraradical hyphae as well as intraradical arbuscules and coils, believed to be linked to plant-fungus substance exchange (Smith and Smith, 1997), are thought to be related to AMF functioning and may vary in occurrence depending on the P limitation (Johnson et al., 2003b). The amount of P transferred to plants is related to the extraradical hyphal length (Jakobsen et al., 2001), depends on the identity and effectiveness of the fungal species (Klironomos et al., 2000; O'Connor et al., 2002; van der Heijden et al., 1998) and differs among soils (Jakobsen et al., 1992; Jakobsen et al., 2001). Varying $\mathrm{P}$ content and biomass of plants growing with different AMF species point to different selectivity and functionality depending on the plant-fungus species combinations (Helgason et al., 2002). Differences in AMF diversity between two grassland species monocultures also point to specific AMF communities associated with plant species (Gollotte et al., 2004). This indicates that the AMF community and its functioning differ depending on the composition and diversity of the associated plant community and that AMF structures related to the functioning of the symbiosis are more abundant under nutrient limiting conditions.

Grassland used as meadow, pasture or mown pasture generally receives nutrients with fertiliser or animal excreta. Nitrogen $(\mathrm{N})$ and phosphorus $(\mathrm{P})$, nutrients that may strongly restrict plant productivity, are the main fertiliser and also occur in notable amounts in urine (Bristow et al., 1992) and faeces (Floate, 1970). The input of $\mathrm{N}$ or P may affect both legumes 
and AMF: The amount of $\mathrm{N}$ fixed by legumes, determined by their yield proportion (Chen et al., 2004) and $\mathrm{N}$ fixation rate (Carlsson, 2005), can be reduced by $\mathrm{N}$ fertilisation (HøghJensen and Schjoerring, 1994). However, high N:P ratios due to $\mathrm{N}$ fertilisation may increase AMF colonisation (Johnson et al., 2003b) caused by P limitation of plants. P application may increase the amount of fixed N (Reed et al., 2007), but can decrease AMF abundance (Covacevich et al., 2006).

Most of the studies investigating relationships between plant diversity, productivity and nutrient use have been carried out on experimentally assembled plant communities of varying plant species number, with the lowest diversity levels usually in the range of one to four species, less than encountered on natural or agricultural mesotrophic permanent grassland. Fertilisation was usually less than under agricultural conditions. In this study, we analysed the effects of grassland composition and fertilisation on nutrient use and productivity in agricultural grassland. We tested the following hypotheses:

1) The nutrient use and productivity of diverse grassland are larger than that of its grassdominated counterpart, related to positive effects of legumes and AMF on $\mathrm{N}$ and $\mathrm{P}$ availability. We expected that in the diverse sward

a. legumes notably increase the amount of biomass $\mathrm{N}$

b. more AMF structures, involved in nutrient uptake and provision, are produced.

2) Productivity and nutrient utilisation are increased by $\mathrm{N}$ or P fertilisation, especially in the grass sward. We expected that

a. the productivity and nutrient uptake of low $\mathrm{N}$ - or P-fertilised grass plots is similar to that of unfertilised diverse control (C) plots;

b. P fertilisation reduces AMF structures involved in nutrient uptake and provision;

c. $\mathrm{N}$ fertilisation decreases the $\mathrm{N}$ fixation of legumes in the diverse sward, but increases AMF structures due to increased P limitation. 


\section{Material and Methods}

The experimental site is a moderately species rich grassland assigned to the plant-sociological community Lolio-Cynosuretum. Abundant grass species were Lolium perenne, Dactylis glomerata and Phleum pratense, Trifolium repens as legume and several forb species. The site

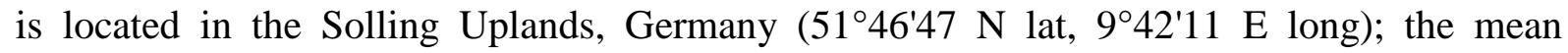
precipitation is $879 \mathrm{~mm}$ and the mean temperature $8.2^{\circ} \mathrm{C}$ per year (Deutscher Wetterdienst 1961-1990, the weather station is located $3 \mathrm{~km}$ away from the experimental site). The soil type is a pelosol with a clayey silt texture. Prior to the experiment, the site had been managed as mown pasture for more than 16 years with varying proportions of cattle and sheep and regular application of light manure. The experimental plots had been excluded from grazing since spring 2007, one year before the start of the experiment; manure had not been applied since 2006. The $\mathrm{pH}$ of the soil (2:5 soil to $0.01 \mathrm{M} \mathrm{CaCl}_{2}$ suspension) and the availability of $\mathrm{P}$, $\mathrm{K}$ (extraction of 1:20 soil to calcium acetate lactate, continuous flow analyzer [CFA]) and $\mathrm{Mg}$ (1:10 soil to $0.0125 \mathrm{M} \mathrm{CaCl}_{2}, \mathrm{CFA}$ ) were variable among treatments and replicates (Tab. 1).

Table 1: $\mathrm{pH}$ and soil nutrient availability (in $\mathrm{mg} 100 \mathrm{~g}^{-1}$ soil, mean \pm standard deviation) in the grass and diverse sward in July 2008.

\begin{tabular}{ccccc}
\hline & $\mathbf{p H}$ & $\mathbf{P}$ & $\mathbf{K}$ & $\mathbf{M g}$ \\
\hline Grass sward & $6.4 \pm 0.1$ & $5.9 \pm 1.3$ & $17.7 \pm 4.3$ & $37.4 \pm 2.5$ \\
Diverse sward & $6.6 \pm 0.1$ & $3.7 \pm 0.8$ & $10.9 \pm 1.2$ & $43.3 \pm 3.0$ \\
\hline
\end{tabular}

Two factors, the plant species composition and soil nutrient availability, were manipulated in this study. The initial vegetation, comprising grasses, forbs and legumes ('diverse sward': $10.6 \pm 0.2$ plant species per $2.5 \mathrm{~m}^{2}$ plot, mean \pm standard deviation, sd at the start of the experiment), was treated with a herbicide against dicotyledonous plants in 2006 ('Starane' and 'Duplosan KV': active components Triclopyr 2-butoxyethylester and Fluroxypyr-1methylheptyl ester or Methylchlor phenoxypropionic acid) to create a grass-dominated sward ('grass sward': $7.0 \pm 0.2$ plant species per plot, mean $\pm \mathrm{sd}$ ). The initial difference in plant species number in 2007 decreased with time, due to the re-establishment of dicot species. However, sward differences in the functional group proportions persisted. Both sward types were either fertilised with a single application of urea (carbamide) nitrogen (N1/ N2: 50 or $500 \mathrm{~kg} \mathrm{~N} \mathrm{ha}^{-1}$, respectively) or superphosphate (calcium dihydrogen phosphate; P1 or P2: 20 or $100 \mathrm{~kg} \mathrm{P} \mathrm{ha}^{-1}$, respectively) or were left untreated (C: control). Experimental plots were 2.5 $\mathrm{m}^{2}$ in size and were arranged as split-plots within diverse and grass sward. The experimental 
treatments were replicated three times in blocks (two sward types $\mathrm{x}$ five treatments $\mathrm{x}$ three blocks $=30$ plots $)$.

The experiment started in June 2008, when the experimental plots were mown and fertilised. Three harvests of aboveground biomass took place in September 2008, June 2009 and September 2009, referred to as harvests one (H1), two (H2) and three (H3). Plots were mown with a motor scythe to $5 \mathrm{~cm}$ sward height. The fresh weight of the biomass was determined and two representative subsamples were taken; one for the analysis with near infra-red spectroscopy (NIRS) and another one for the determination of the yield shares of grasses, legumes and forbs by sorting and drying samples at $105^{\circ} \mathrm{C}$. For NIRS, the sample was dried at $60^{\circ} \mathrm{C}$ for 48 hours, ground to $1 \mathrm{~mm}$ size and the crude protein $(\mathrm{CP})$ content of the herbage was determined (Kesting et al., 2009). The $\mathrm{N}$ content of the forage was calculated from the CP content, based on the assumption of $\mathrm{CP}$ containing $16 \% \mathrm{~N}$. For analysis of the $\mathrm{P}$ and $\mathrm{K}$ content, the samples were digested in nitrohydrochloric acid for two hours $(1 \mathrm{~g}$ sample, $9 \mathrm{ml}$ $\mathrm{HCl}$ and $4 \mathrm{ml} \mathrm{HNO}_{3}$ ), $2 \mathrm{M} \mathrm{HCl}$ was added up to a total volume of $50 \mathrm{ml}$ and $\mathrm{P}$ was measured by an inductively coupled plasma emission spectrometer. The apparent fertiliser use efficiency (\%) was determined for $\mathrm{N}$ and P (ANE and APE, respectively) as the uptake of the fertilised treatment minus the uptake of the control, divided by the amount of fertiliser used.

Roots and soil were sampled in July 2008 and 2009 to a depth of $15 \mathrm{~cm}$, with a soil corer of $4.9 \mathrm{~cm}$ in diameter. For analysis of roots and AMF in roots and soil, two cores per plot were taken in 2008 and four cores per plot were taken in 2009 and stored cool until returning to the laboratory. These cores were analysed separately and pooled for statistical analysis. Subsamples were obtained from the soil cores to conduct root and soil analyses (Fig. 1).

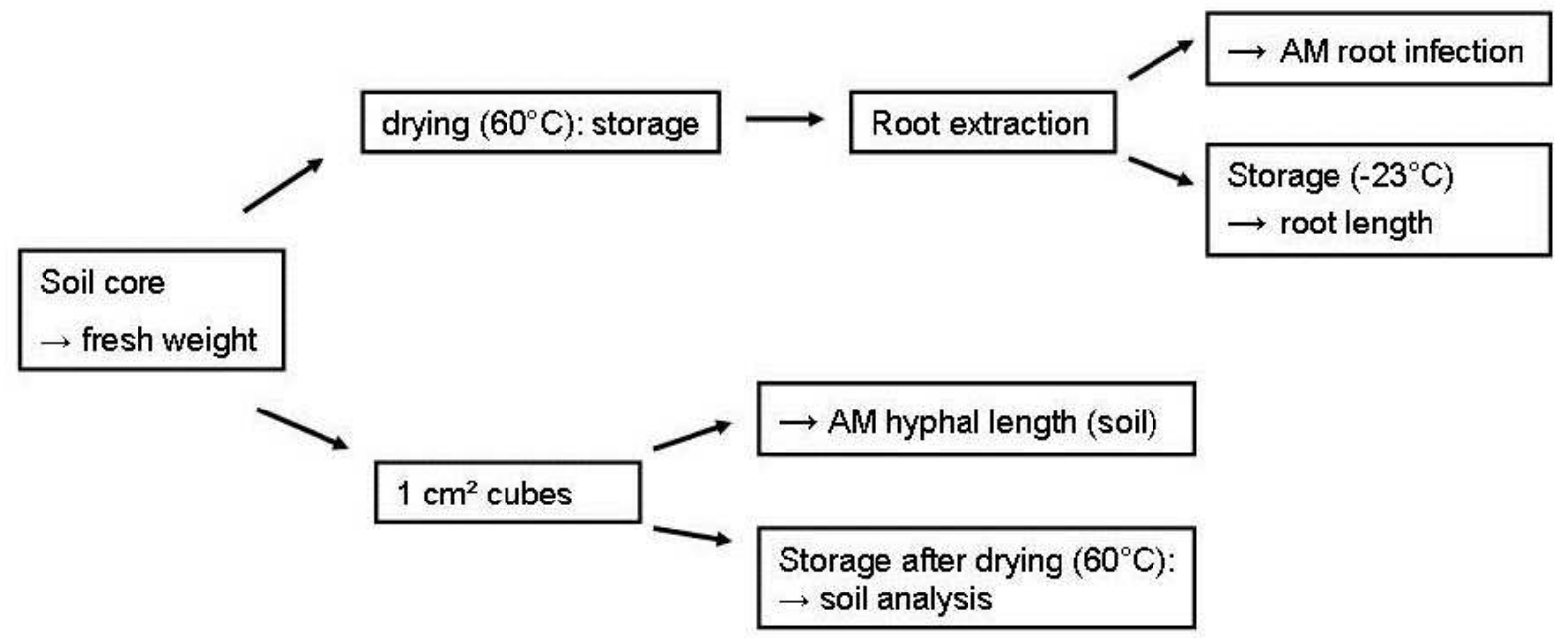

Figure 1: Approach of subsampling for root and soil analyses. AM = arbuscular mycorrhiza. 
The extraction of roots from the soil was carried out as described by Jung (2003). For analysis of root infection with AMF structures, roots were stained with black ink (Vierheilig et al., 1998), stored in lactoglycerol (4:2:1 lactic acid: glycerol: distilled water) and percent infection with arbuscules, coils, vesicles and AMF as well as non-AMF hyphae was determined with the gridline intersect method (McGonigle et al., 1990) at 400x magnification (100 gridlines per subsample; compound microscope). A representative root subsample was scanned and the root length was measured using WinRhizo software (Version 2007d, Instrument Regent Inc., Quebec, Canada). Both, the scanned and the remaining subsample were dried at $105^{\circ} \mathrm{C}$ and weighed; total root length per sample was calculated based on the weight proportion of the scanned subsample.

Extraradical hyphae were extracted from soil according to the membrane filter technique after Rillig (1999) with few modifications: in the first step, the soil was extracted in a mixture of $100 \mathrm{ml}$ tap water and $12 \mathrm{ml}$ sodiumhexametaphosphate $\left(35 \mathrm{~g} \mathrm{l}^{-1}\right)$; a $40 \mu \mathrm{m}$ sieve was used to retain fungal hyphae. Hyphae were stained for 10 minutes with a solution of $0.01 \%$ Trypan Blue in 2:1:1 lactic acid : glycerol : deionised water. The soil and aliquot volume were varied depending on the density of hyphae in the samples. Two filter papers per soil extract were used to determine extraradical hyphal length. To this end, 100 stratified random fields of view were examined at $200 \times$ magnification with a compound microscope and rated according to the gridline intersect method; hyphal length was determined according to Tennant (1975). The differentiation in AMF and non-AMF hyphae within roots and in the soil was done according to Rillig (1998).

To determine the nitrogen $\mathrm{N}$ derived from the atmosphere (Ndfa) by the legumes, the ${ }^{15} \mathrm{~N}$ natural abundance method (Amarger et al., 1979) was used. Legumes and grasses as non-N fixing reference plants were sampled. Legumes and grasses were sampled indifferent of the species in 2008. As there might be species-specific differences in $\mathrm{N}$ fixation or assimilation, the legume Trifolium repens, which was generally abundant in the experimental plots and Dactylis glomerata as reference plant were sampled in 2009. Medicago lupulina was sampled as a second legume, as T. repens was substituted by M. lupulina in some plots. Samples were dried at $60^{\circ} \mathrm{C}$ for $48 \mathrm{~h}$, ground to $0.25 \mathrm{~mm}$ and analysed with an isotope ratio mass spectrometer Delta Plus, Finnigan MAT (Bremen, Germany). The ${ }^{15} \mathrm{~N}$ signature $\left(\delta^{15} \mathrm{~N}\right)$ of the sample was determined using an elemental analyser NA1110 (CE -Instruments, Rodano, Milano, Italy), connected through a Conflo III-Interface (Finnigan MAT, Bremen, Germany) to the mass spectrometer. $\mathrm{N}_{2}$ was calibrated against the reference substances $\mathrm{N} 1$ and $\mathrm{N} 2$ 
(IAEA, Vienna) and served as reference gas. As internal standard, acetanilide was used. The Ndfa was calculated as follows:

Ndfa [\%] $=\left(\delta^{15} \mathrm{~N}_{\text {grass }}-\delta^{15} \mathrm{~N}_{\text {legume }}\right) /\left(\delta^{15} \mathrm{~N}_{\text {grass }}-\mathrm{B}\right)$, (Shearer and Kohl, 1986).

$\mathrm{B}$ is the $\delta^{15} \mathrm{~N}$ of a legume grown on an $\mathrm{N}$-free medium, receiving all $\mathrm{N}$ from the atmosphere. As B value, $-1.6 \%$, the mean B determined for six common legumes in our latitude, was used (Klatt, 2008). Mean grass $\delta^{15} \mathrm{~N}$ values per block were used as $\delta^{15} \mathrm{~N}_{\text {grass. }}$ The contribution of $\mathrm{N}$ fixed by legumes to total $\mathrm{N}$ was calculated as follows:

Legume yield $\left[\mathrm{kg} \mathrm{ha}^{-1} \mathrm{a}^{-1}\right]=$ standing biomass $\left[\mathrm{kg} \mathrm{ha}^{-1} \mathrm{a}^{-1}\right] *$ legume yield share $[\%] / 100$, $\mathrm{N}$ content legumes $\left[\mathrm{kg} \mathrm{ha}^{-1} \mathrm{a}^{-1}\right]=$ Legume yield $\left[\mathrm{kg} \mathrm{ha}^{-1} \mathrm{a}^{-1}\right] * \mathrm{~N}$ content $[\%] / 100$, $\mathrm{N}_{\text {fixed }}\left[\mathrm{kg} \mathrm{ha}^{-1} \mathrm{a}^{-1}\right]=\mathrm{N}$ content legumes $\left[\mathrm{kg} \mathrm{ha}^{-1} \mathrm{a}^{-1}\right] * \mathrm{Ndfa}[\%] / 100$,

Contribution of $\mathrm{N}$ fixed by legumes to total $\mathrm{N}[\%]=\mathrm{N}_{\text {fixed }}\left[\mathrm{kg} \mathrm{ha}^{-1} \mathrm{a}^{-1}\right] /($ standing biomass $[\mathrm{kg}$ $\left.\mathrm{ha}^{-1} \mathrm{a}^{-1}\right]^{*} \mathrm{~N}$ content [\%]) $* 100$.

At each biomass or soil/root harvest, plant species composition of the plots was determined and their cover was estimated (Braun-Blanquet method). Species' yield shares in \% were calculated based on their cover as described in Voigtländer and Voss (1979).

Statistics were done with R (Development Core Team, 2010). Split plot analyses of variance were performed with fertilisation nested in sward, which again was nested in the random factor block. ANOVAs based on single measurement dates, as well as repeated measurement ANOVAs, based on linear mixed effects models, were performed for the biomass, plant species number, legume yield, Ndfa, uptake and concentrations of $\mathrm{N}, \mathrm{P}, \mathrm{K}$, root length infected with arbuscules and coils (AC root length) and extraradical hyphal length. To answer hypothesis $2 \mathrm{a}$ of differences among treatments across swards, a factor combining sward and fertilisation was created. Analyses of covariance (ANCOVAs) were performed for the biomass yields with the yield share of dominant grass species as covariable. Common visual tests were applied to test the requirements for the performance of parametric tests (normal QQ plot: normal distribution of the residuals; residuals versus fitted values plot: variance homogeneity). Kruskal-Wallis tests were performed if the assumptions for parametric tests were not met. $P$ values in post hoc multiple comparisons were adjusted according to Tukey. Spearman correlations were performed to analyse the relationship between plant species number, N:P, $\mathrm{N}$ and $\mathrm{P}$ in the biomass and specific root length (SRL), AC root length, extraradical and non-AMF hyphal length. 


\section{Results}

Biomass yields were significantly larger in the grass than in the diverse sward at $\mathrm{H} 1$ and $\mathrm{H} 3$ ( $P=0.014$ and $P=0.049$, respectively). The sward type had no effect on the cumulative yields over all harvests (Fig. 2), but had an effect when harvest date was considered as repeated measurement factor $(P=0.018)$. When comparing treatments across sward types, the $\mathrm{N} 2$ grass plots yielded more biomass than all other treatments at $\mathrm{H} 1(P=0.004)$. At $\mathrm{H} 3$, all grass plots and the diverse $\mathrm{P} 2$ treatment had a significantly larger yield than the diverse $\mathrm{C}(P$ $<0.001)$. The cumulative biomass was significantly larger in the N2 grass than in the diverse C plots $(P=0.031)$; the yields of all other treatments were intermediate and did not differ from either of these treatments (Fig. 2).

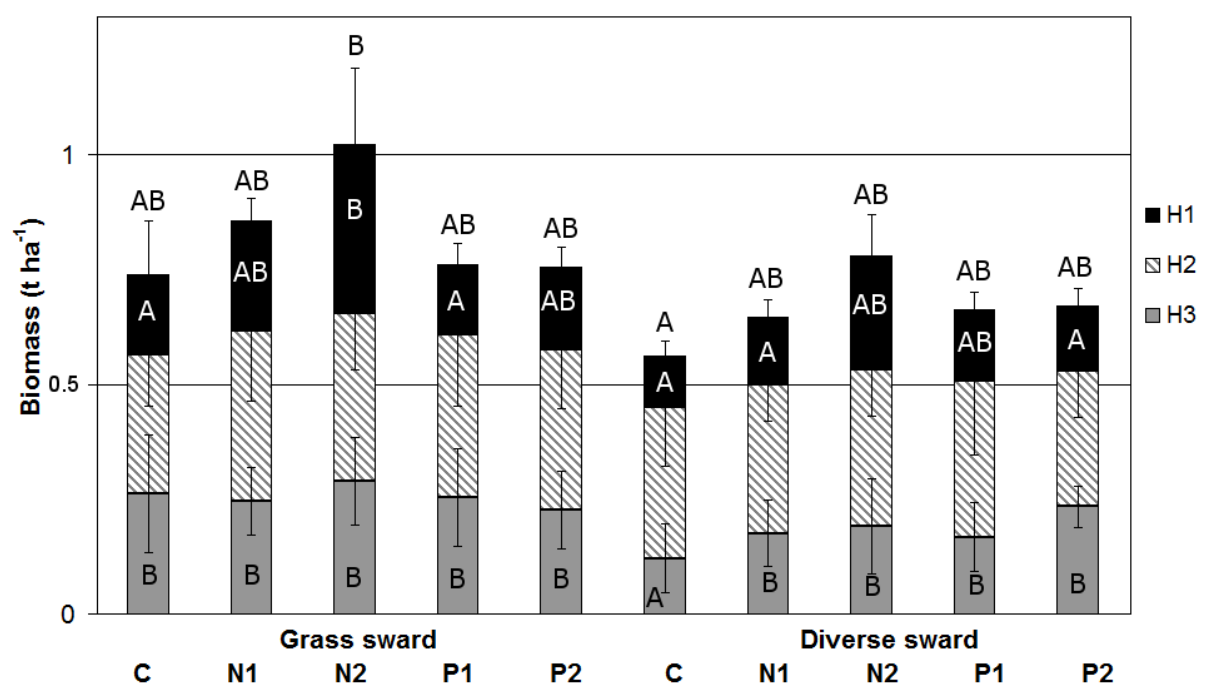

Figure 2: Biomass yields of the three harvests after fertilisation (H1: September 2008, H2: June 2009, H3: September 2009; means $\pm \mathrm{sd}$ ) for the different treatments (C: control, N1: $50 \mathrm{~kg} \mathrm{~N}^{-1}, \mathrm{~N} 2: 500$ $\mathrm{kg} \mathrm{N} \mathrm{ha}^{-1}, \mathrm{P} 1: 20 \mathrm{~kg} \mathrm{P} \mathrm{ha}^{-1}$, P2: $100 \mathrm{~kg} \mathrm{P} \mathrm{ha}^{-1}$ ) within grass and diverse sward. Differences among treatments $(P<0.05)$ across sward types are indicated by capital letters: within columns for single harvests and above the respective columns for the accumulated harvests.

The grass species Dactylis glomerata, Lolium perenne and Phleum pratense had a large share in the yield in both sward types at the first two harvests; e.g. at H1, they made up $53 \pm 17$ and $30 \pm 3 \%$ of the yield in the grass and diverse sward, respectively (mean $\pm \mathrm{sd}$ ). When considered as covariable, the total yield shares of these dominant grasses had a significant effect on biomass production at $\mathrm{H} 2$ and $\mathrm{H} 3$. The sward effect on the biomass yield was then more pronounced at $\mathrm{H} 1(P=0.003)$ and $\mathrm{H} 3(P<0.001)$. In both sward types, fertiliser treatment effects remained as described above when the yield share of the dominant grasses was accounted for as covariable, but was smaller in the diverse sward at H1 $(P=0.043)$. 


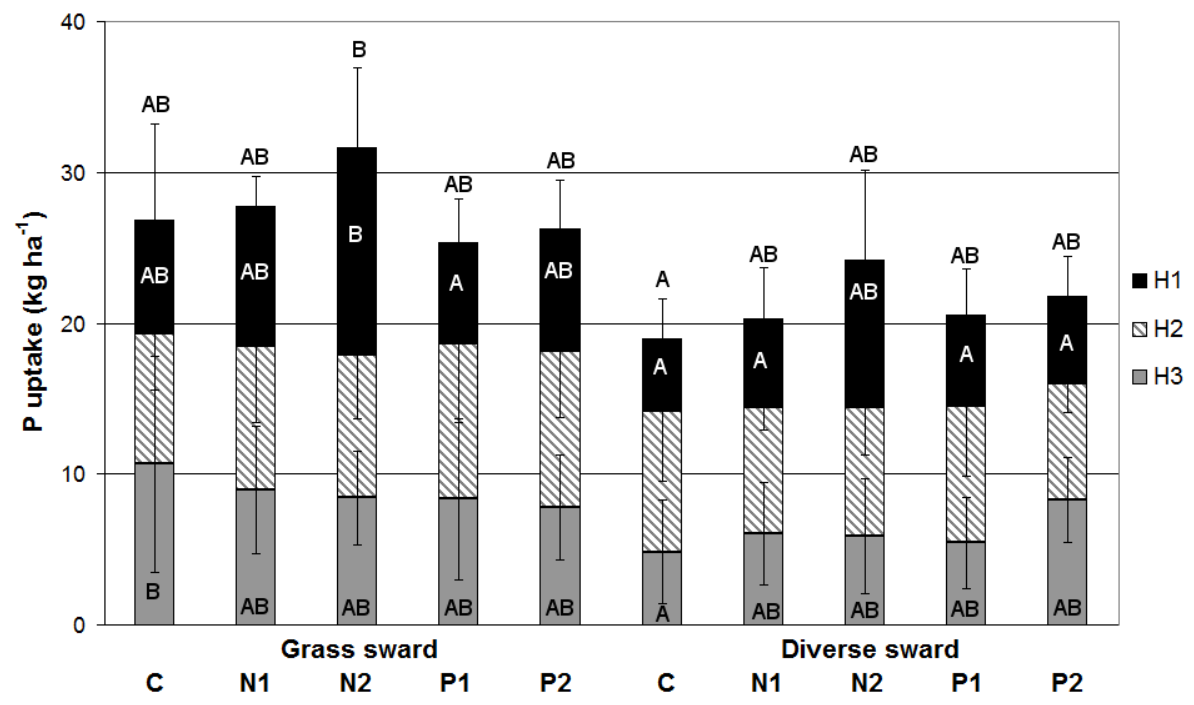

Figure 3: Phosphorus uptake of the three harvests after fertilisation (H1: September 2008, H2: June 2009, H3: September 2009; means \pm sd) for the different treatments (C: control, N1: $50 \mathrm{~kg} \mathrm{~N} \mathrm{ha}^{-1}, \mathrm{~N} 2$ : $500 \mathrm{~kg} \mathrm{~N} \mathrm{ha}^{-1}$, P1: $20 \mathrm{~kg} \mathrm{Pha}^{-1}$, P2: $100 \mathrm{~kg} \mathrm{Pha}^{-1}$ ) within grass and diverse sward. Differences among treatments $(P<0.05)$ across sward types are indicated by capital letters: for single harvests within and for the accumulated harvests above the respective columns.

In repeated measurement ANOVAs, there was a significant sward effect on the uptake of $\mathrm{P}$ and $\mathrm{K}(P<0.001$ for $\mathrm{P}$ and $\mathrm{K}$, respectively), but not on that of $\mathrm{N}$. Both $\mathrm{P}$ and $\mathrm{K}$ uptake were larger in the grass than in the diverse sward (by $30 \%$ for $\mathrm{P}$ and $\mathrm{K}$, respectively; both $P<$ 0.001; Fig. 3 and 4). The sward had no significant effect on the accumulated uptake of $\mathrm{P}, \mathrm{N}$ or $\mathrm{K}$ over all harvests. Across swards, $\mathrm{P}$ uptake was largest in the $\mathrm{N} 2$ grass treatment at H1, in the $\mathrm{C}$ grass treatment at H3, and was smallest in the diverse C (Fig. 3) at both harvests. The accumulated $\mathrm{P}$ uptake was significantly larger in the grass $\mathrm{N} 2$ than in the diverse $\mathrm{C}$ plots $(P=$ 0.030). The $P$ concentration of the vegetation was unaffected by fertilisation and sward type.

The $\mathrm{K}$ uptake was largest in the $\mathrm{N} 2$ grass treatment at $\mathrm{H} 1(P=0.003)$ and significantly larger in N2 grass compared to the diverse $\mathrm{C}$ and $\mathrm{P} 1$ at $\mathrm{H} 3(P=0.013$, Fig. 4). When accumulated over three harvests, the K uptake of the $\mathrm{N} 2$ grass treatment was significantly larger compared to all treatments of the diverse sward, except for the diverse $\mathrm{N} 2$ treatment $(P=0.014)$. The $\mathrm{K}$ concentration of the vegetation did not differ among swards or fertilisation treatments. 


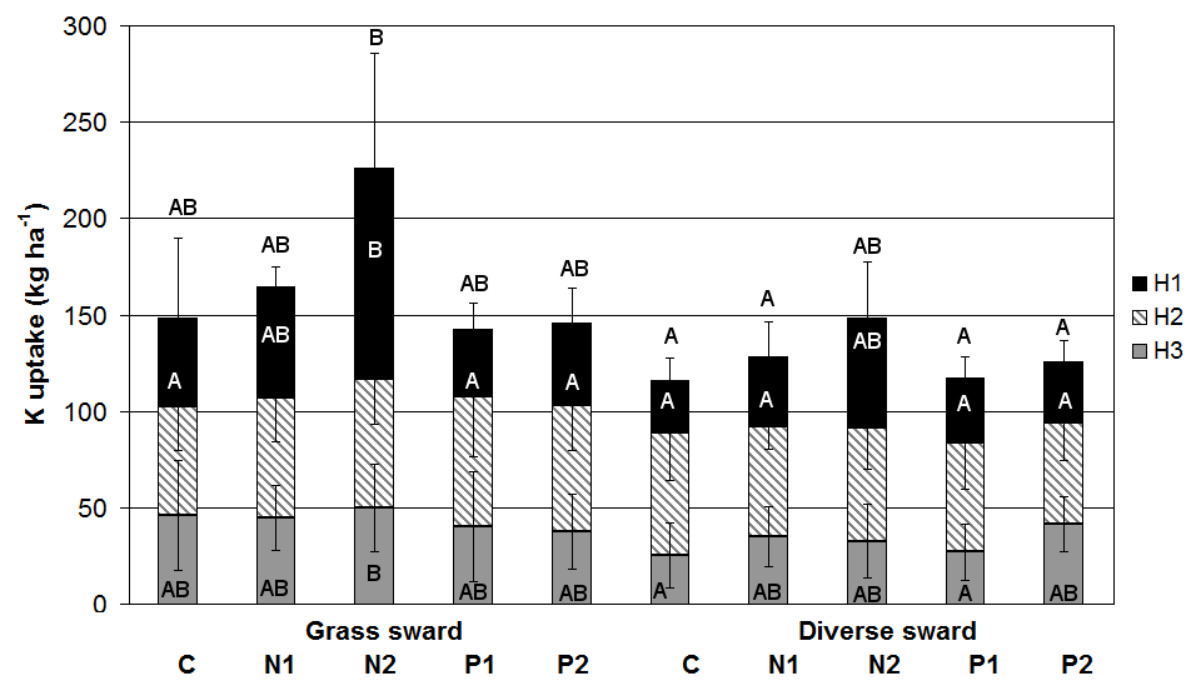

Figure 4: Potassium uptake of the three harvests after fertilisation (H1: September 2008, H2: June 2009, H3: September 2009; means \pm sd) for the different treatments (C: control, N1: $50 \mathrm{~kg} \mathrm{~N} \mathrm{ha}^{-1}, \mathrm{~N} 2$ : $500 \mathrm{~kg} \mathrm{~N} \mathrm{ha}^{-1}$, P1: $20 \mathrm{~kg} \mathrm{Pha}^{-1}, \mathrm{P} 2: 100 \mathrm{~kg} \mathrm{Pha}^{-1}$ ) within grass and diverse sward. Differences among treatments $(P<0.05)$ across sward types are indicated by capital letters: for single harvests within and for the accumulated harvests above the respective columns.

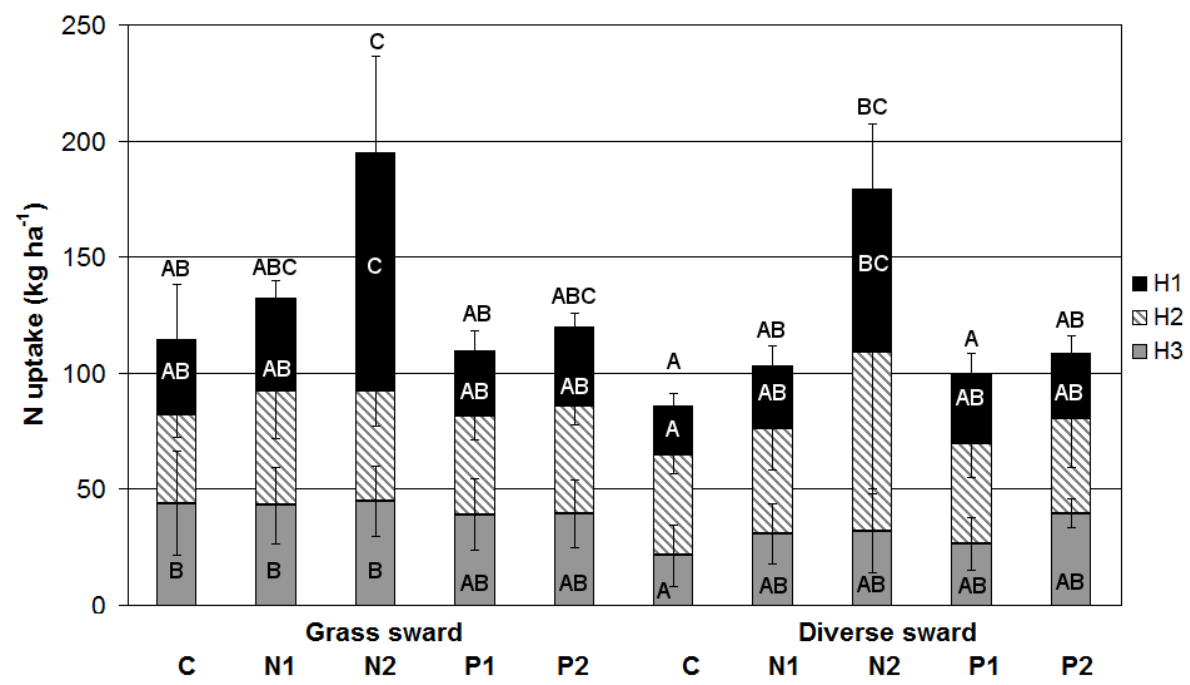

Figure 5: Nitrogen uptake of the three harvests after fertilisation (H1: September 2008, H2: June 2009, H3: September 2009; means \pm sd) for the different treatments (C: control, N1: $50 \mathrm{~kg} \mathrm{~N}^{-1}, \mathrm{~N} 2$ : $500 \mathrm{~kg} \mathrm{~N} \mathrm{ha}^{-1}, \mathrm{P} 1: 20 \mathrm{~kg} \mathrm{P} \mathrm{ha}^{-1}, \mathrm{P} 2: 100 \mathrm{~kg} \mathrm{P} \mathrm{ha}^{-1}$ ) within grass and diverse sward. Differences among treatments $(P<0.05)$ across sward types are indicated by capital letters: for single harvests within and for the accumulated harvests above the respective columns.

The $\mathrm{N}$ uptake across swards was significantly larger in the diverse $\mathrm{N} 2$ compared to the diverse $\mathrm{C}$ treatment and in the grass $\mathrm{N} 2$ compared to all other treatments with exception of the diverse $\mathrm{N} 2$ plots at $\mathrm{H} 1(P<0.001)$. At $\mathrm{H} 3$, the $\mathrm{N}$ uptake was larger in the grass $\mathrm{C}, \mathrm{N} 1$ and $\mathrm{N} 2$ plots 
than in the diverse $\mathrm{C}$ treatment $(P=0.007)$. When accumulated over the harvests, in both swards, the $\mathrm{N}$ uptake was larger in the $\mathrm{N} 2$ than in the respective $\mathrm{C}$ and $\mathrm{P} 1$ treatments, was similar between the N2 plots of both swards, and, apart from that, was larger in the grass N2 than the other grass $(P=0.007)$ or diverse treatments $(P=0.003$, Fig. 5$)$. The $\mathrm{N}$ concentration was significantly larger in the $\mathrm{N} 2$ grass and diverse treatments compared to the other treatments at H1 ( $P \leq 0.001$ for grass and diverse sward, respectively; data not shown) but not at the later harvests.

The ANE was larger in the N1 compared to the N2 treatment in the diverse sward at H3 (19.0 \pm 4.5 vs. $2.1 \pm 2.2 \%, P=0.007)$ and was -when compared across swards- significantly larger in the diverse $\mathrm{N} 1$ compared to both $\mathrm{N}$ grass treatments $(-2.0 \pm 12.2$ and $0.2 \pm 2.6$, for $\mathrm{N} 1$ and N2, respectively; $P=0.009)$. Compared across swards, both diverse $\mathrm{P}$ treatments $(3.0 \pm 3.1$ and $3.4 \pm 0.9 \%$, for P1 and P2, respectively) had significantly larger APE than the grass P1 treatment $(-11.5 \pm 8.9 \%, P=0.024)$ at H3. The accumulated ANE and APE over the three harvests did not differ among treatments within or across swards $(36.4 \pm 49.6$ and $16.2 \pm 4.7$ vs. $34.8 \pm 38.5$ and $18.8 \pm 9.0$, for $\mathrm{N} 1$ and $\mathrm{N} 2$ in grass vs. diverse sward, respectively; $-7.4 \pm$ 14.8 and $-0.6 \pm 6.1$ vs. $7.5 \pm 10.2$ and $2.8 \pm 6.8$ for P1 and P2 in grass vs. diverse sward, respectively).

Table 2: Legume yield and $\mathrm{N}$ derived from air (Ndfa) for the fertilisation treatments (C: control, N1: $50 \mathrm{~kg} \mathrm{~N}^{-1}, \mathrm{~N} 2: 500 \mathrm{~kg} \mathrm{~N}^{-1}, \mathrm{P} 1: 20 \mathrm{~kg} \mathrm{P} \mathrm{ha}^{-1}, \mathrm{P} 2: 100 \mathrm{~kg} \mathrm{P} \mathrm{ha}^{-1}$ ) in the diverse sward at the first harvest (H1) and accumulated over the three harvests ( $\Sigma \mathrm{H} 1-3)$; legume yield and Ndfa are not shown for the grass sward due to the absence of legumes (except for one plot). Fertilisation treatment (T) effects are shown in the respective column (ns: not significant).

\begin{tabular}{|c|c|c|c|c|c|c|c|}
\hline & & \multicolumn{5}{|c|}{ diverse sward } & \multirow[b]{2}{*}{$\mathbf{T}$} \\
\hline & & C & N1 & N2 & P1 & P2 & \\
\hline $\begin{array}{l}\text { Legume yield, \% } \\
\text { Ndfa, } \mathrm{kg} \mathrm{ha}^{-1}\end{array}$ & $\begin{array}{c}\mathrm{H} 1 \\
\mathrm{H} 1 \\
\Sigma \mathrm{H} 1-3\end{array}$ & $\begin{array}{l}3.65 \pm 3.70 \\
0.40 \pm 0.12 \\
3.20 \pm 2.44\end{array}$ & $\begin{array}{l}0.11 \pm 0.10 \\
0.02 \pm 0.03 \\
1.07 \pm 0.90\end{array}$ & $\begin{array}{l}0.00 \pm 0.00 \\
0.00 \pm 0.00 \\
0.27 \pm 0.29\end{array}$ & $\begin{array}{l}1.28 \pm 0.98 \\
0.31 \pm 0.31 \\
1.40 \pm 1.47\end{array}$ & $\begin{array}{l}4.91 \pm 6.75 \\
1.16 \pm 1.36 \\
1.40 \pm 0.26\end{array}$ & $\begin{array}{l}\mathrm{ns} \\
0.044 \\
\mathrm{~ns}\end{array}$ \\
\hline
\end{tabular}

In the grass sward, legumes did not exceed a mean yield proportion of $1 \%$ (when averaged across treatments; data not shown). In the diverse sward, the legume yield was generally smallest in the N2 treatments (Tab. 2); at $\mathrm{H} 3$, the legume yield was significantly larger in $\mathrm{C}$ compared to the other treatments $(P=0.009$; data not shown). The amount of symbiotically fixed $\mathrm{N}$ was significantly larger in $\mathrm{C}$ and $\mathrm{P} 2$ compared to the other treatments at $\mathrm{H} 1(P=$ 0.044; Tab. 2); in the following harvests, fixed $\mathrm{N}$ was unaffected by fertilisation. Fertilisation 
treatment had no effect on the cumulative amount of fixed $\mathrm{N}$, but had a significant effect when harvests were accounted for in a repeated measurement ANOVA $(P=0.028)$.

Table 3: Plant species number, length of root infected with arbuscules and coils (AC root length), extaradical hyphal length and N:P ratio in the biomass (one month before sampling roots and AMF) within treatments (C: control, N2: $500 \mathrm{~kg} \mathrm{~N} \mathrm{ha}^{-1}, \mathrm{P} 2: 100 \mathrm{~kg} \mathrm{P} \mathrm{ha}^{-1}$ ) in grass and diverse sward in 2009. Differences among variants within sward type are indicated by small letters, effects of sward $(\mathrm{Sw})$ and its interaction with fertilisation treatment $(\mathrm{Sw} \times \mathrm{T})$ are indicated in the respective columns.

\begin{tabular}{|c|c|c|c|c|c|c|c|}
\hline \multicolumn{3}{|c|}{ grass sward } & \multicolumn{3}{|c|}{ diverse sward } & \multirow[b]{2}{*}{ Sw } & \multirow[b]{2}{*}{ Sw $x \mathrm{~T}$} \\
\hline C & N2 & $\mathbf{P 2}$ & C & N2 & $\mathbf{P 2}$ & & \\
\hline \multicolumn{8}{|c|}{ Species number } \\
\hline $6.7 \pm 1.2^{\mathrm{a}}$ & $7.7 \pm 0.6^{\mathrm{ab}}$ & $12.3 \pm 1.5^{\mathrm{b}}$ & $10.0 \pm 1.0$ & $11.0 \pm 1.0$ & $9.0 \pm 1.0$ & $\mathrm{~ns}$ & 0.004 \\
\hline \multicolumn{8}{|c|}{$\mathrm{N}: \mathrm{P}$ ratio } \\
\hline $4.7 \pm 1.3$ & $5.3 \pm 0.8$ & $5.0 \pm 1.7$ & $5.4 \pm 2.6$ & $9.8 \pm 8.9$ & $5.2 \pm 1.6$ & $\mathrm{~ns}$ & ns \\
\hline \multicolumn{8}{|c|}{ AC root length, $\mathrm{cm} \mathrm{g}^{-1}$} \\
\hline $0.6 \pm 0.2$ & $0.5 \pm 0.2$ & $1.1 \pm 0.6$ & $0.8 \pm 0.7$ & $1.5 \pm 0.7$ & $1.1 \pm 0.5$ & $\mathrm{~ns}$ & ns \\
\hline \multicolumn{8}{|c|}{ Extraradical hyphal length, $\mathrm{cm} \mathrm{g}^{-1}$} \\
\hline $170.5 \pm 151.9$ & $108.2 \pm 45.4$ & $135.1 \pm 29.7$ & $152.8 \pm 43.5$ & $144.9 \pm 56.7$ & $117.8 \pm 35.6$ & $\mathrm{~ns}$ & ns \\
\hline
\end{tabular}

The extraradical hyphal length in the soil was significantly larger in the diverse compared to the grass sward one month after fertilisation in July 2008 (2.5 \pm 0.3 vs. $1.8 \pm 0.3 \mathrm{~m} \mathrm{~g}^{-1}$ soil; $P$ $=0.033)$, fertilisation had no effect on extraradical hyphal length. Plant species numbers were not significantly different between swards at that time, but the grass proportion was significantly smaller and the legume proportion larger in the diverse compared to the grass sward (92 vs. $99 \%$ grass, $P=0.018$ and 1.9 vs. $0 \%$ legumes, $P<0.001)$. No effects of sward or fertilisation on $\mathrm{AC}$ root length or on $\mathrm{N}: \mathrm{P}$ ratio in the biomass in 2008 were found (data not shown).

One year after the fertilisation treatment, plant species numbers were significantly larger in the diverse compared to the grass sward $(P=0.022)$ and in the $\mathrm{C}$ compared to the $\mathrm{N} 2$ treatment in the diverse sward $(P=0.032)$. Yield proportions of grass, forbs and legumes were still different between swards (96 vs. $75 \%$ grass, 3 vs. $18 \%$ forbs and 0 vs. $8 \%$ legumes in June in the grass and diverse sward, respectively), but only differed significantly with respect to the legume content $(P=0.002)$. Sward type and fertilisation had no significant effect on AC root length, extraradical hyphal length, N:P ratio in the biomass (Tab. 3) or SRL (data not shown). The correlation of variables measuring AMF functioning (root length infected with AMF structures, AC root length, extraradical hyphal length) and SRL with plant species number, $\mathrm{N}: \mathrm{P}$ ratio, $\mathrm{N}$ or $\mathrm{P}$ in the biomass in most cases did not yield any consistent relationships for the sward types and the two years (Tab. 4). Percent infection with arbuscules 
and coils, with vesicles, hyphae or all AMF structures were not related to N:P in biomass or species richness and were unaffected by sward type and fertilisation (data not shown).

Table 4: Spearman correlation coefficients for the relationship of the variables root length infected with mycorrhizal structures ( $\mathrm{RL}_{\text {infected }}$ ), root length infected with arbuscules and coils (AC root length), extraradical hyphal length (extraradical hyphal length) and SRL (specific root length) with plant species number (species no.), $\mathrm{N}: \mathrm{P}$ ratio, $\mathrm{N}$ or $\mathrm{P}$ content $\left(\mathrm{g} \mathrm{kg}^{-1}\right)$ in the biomass in the grass $(\mathrm{G})$ or diverse sward (D) in 2008 and 2009. Significant correlations $(P \leq 0.05)$ are in bold, other correlations shown were marginally significant $(P \leq 0.07)$, empty cells indicate non-significant correlations.

\begin{tabular}{cccccc}
\hline & & \multicolumn{2}{c}{ Grass } & \multicolumn{2}{c}{ Diverse } \\
\cline { 3 - 6 } & & 2008 & 2009 & 2008 & 2009 \\
\hline SRL & Species no. & $\mathbf{0 . 6 1}$ & -0.60 & & \\
& $\mathrm{~N}: \mathrm{P}$ & & & & \\
$\mathrm{N}$ & $\mathbf{- 0 . 5 3}$ & & & \\
& $\mathrm{P}$ & & & & \\
& Species no. & $\mathbf{0 . 8 8}$ & & \\
$\mathrm{N}: \mathrm{P}$ & & & & \\
& $\mathrm{N}$ & & & $\mathbf{- 0 . 7 0}$ & \\
& $\mathrm{P}$ & & & $\mathbf{- 0 . 5 4}$ & \\
\hline RL infected & Species no. & & 0.66 & & \\
& $\mathrm{~N}: \mathrm{P}$ & & & & \\
& $\mathrm{N}$ & & & & \\
& $\mathrm{P}$ & & & & \\
\hline extraradical hyphal length length & Species no. & & & \\
& $\mathrm{N}: \mathrm{P}$ & & & 0.52 & $\mathbf{0 . 6 8}$ \\
& $\mathrm{N}$ & & $\mathbf{0 . 7 3}$ & & $\mathbf{0 . 8 5}$ \\
& $\mathrm{P}$ & $\mathbf{- 0 . 6 1}$ & & & \\
& & & &
\end{tabular}




\section{Discussion}

In the following, we will first discuss the effects of sward composition on biomass production and nutrient uptake and then analyse $\mathrm{N}$ or $\mathrm{P}$ fertilisation effects on productivity and nutrient use across the grass and diverse swards.

Our first hypothesis of larger nutrient uptake and consequently larger productivity in the diverse compared to the grass sward has to be rejected. The biomass production accumulated over harvests was similar between swards; at H1 and H3, the grass sward was even more productive than the diverse sward. Outstanding is the much larger biomass (48\% on average) of the grass compared to the diverse $\mathrm{N} 2$ treatment at $\mathrm{H} 1$. These effects seem to be due to a higher abundance of high yielding grass species in the grass sward, some possibly reaching their maximum yield at relatively high nutrient levels, as was shown e.g. for D. glomerata (Austin and Austin, 1980).

Our findings contradict earlier studies in experimental grasslands of decreasing biomass with lower functional group (Hector et al., 1999; Hooper and Vitousek, 1997) or plant species number (Fridley, 2002). Unlike these studies, until one year before the experiment started, our experimental site was used for grazing. Grazing can increase nutrient availability, due to faster nutrient return to soils by animal faeces and less nutrient immobilisation by microbes, related to decreased investment of plants in roots (Hobbie, 1992). This may have led to similar and equally adequate nutrient availability in both swards. Furthermore, our grass sward reached similarly high plant species numbers $\left(7.9 \pm 2.1\right.$ species per $2.5 \mathrm{~m}^{2}$ in June 2008 , mean $\pm \mathrm{sd}$ ) as high-diversity treatments in some experimental studies (8 species vs. 1, 2, and 4 in the low-diversity treatments: Tilman et al., 2001; van Ruijven and Berendse, 2005), even though our reference scale was larger ( 2.5 vs. $1 \mathrm{~m}^{2}$ plots $)$. Thus, the suggested threshold of five plant species for finding diversity effects on productivity was exceeded (Roy, 2001); complementary resource use may, therefore, have been similarly important in both sward types. Besides, under conditions of sufficient nutrient availability, the relevance of complementary nutrient use would be minor.

Our hypothesis of higher nutrient utilization in swards of higher diversity was not confirmed; the accumulated uptake of N, P and K was similar between swards. Even though repeated measurement ANOVAs pointed to significant sward effects in case of $\mathrm{P}$ and $\mathrm{K}$ uptake $(P<$ 0.001 for $\mathrm{P}$ and $\mathrm{K}$, respectively), these were due to biomass differences between swards at two harvests (no significant effect of sward type on $\mathrm{P}$ or $\mathrm{K}$ uptake in ANCOVAs with biomass as covariable). In other studies, the $\mathrm{N}$ concentration in the biomass (Pan et al., 2010) and $\mathrm{N}$ uptake (Spehn et al., 2002) were found to be related to vegetation composition, plant 
species richness and the presence of legumes. In our study, the contribution of legumes to the $\mathrm{N}$ supply in the diverse sward was -contrary to our hypothesis- negligible, as legume yields were small at all harvests (on average $2.0 \pm 2.2,7.5 \pm 7.6$ and $0.7 \pm 0.7 \%$, for $\mathrm{H} 1, \mathrm{H} 2$ and $\mathrm{H} 3$, respectively). Therefore, the amount of fixed $\mathrm{N}$ accumulated over harvests did not exceed 3 $\mathrm{kg} \mathrm{ha}^{-1}$ in the diverse $\mathrm{C}$ treatment, corresponding to $0.13 \mathrm{~kg} \mathrm{ha}^{-1}$ per $1 \%$ legume yield. This is a relatively small fixation rate, as fixed $\mathrm{N}$ can reach values of 0.68 to $1.05 \mathrm{~kg} \mathrm{ha}^{-1}$ per $1 \%$ legume yield (Eriksen et al., 2004). There were several reasons for these small amounts of fixed N: The low management intensity of two cuts per year facilitated the dominance of grasses, whereas the legume abundance decreased. Furthermore, a sufficient $\mathrm{N}$ availability in the diverse swards and low precipitation rates occurring from April to October in 2008 and 2009 (417 and $408 \mathrm{~mm}$, respectively) likely contributed to a decrease in $\mathrm{N}$ fixation and legume abundance (Serraj et al., 1999). The utilisation efficiency of fertiliser N and P seemed to be similar between sward types; although ANE or APE were significantly larger in the diverse $\mathrm{N} 1$ or the diverse $\mathrm{P} 1$ and $\mathrm{P} 2$ compared to the other treatments at $\mathrm{H} 3$, no effects on accumulated ANE and APE were found.

Complementary effects on nutrient use may increase with time of vegetation establishment (Hooper and Dukes, 2004) and were also found in the absence of legumes (van Ruijven and Berendse, 2005). In our study, no productivity-independent complementary effects, related to larger resource use, as found by Hooper and Vitousek (1998), could be observed, even though the diverse swards had persisted for at least 16 years.

Contrary to our expectation, the sward composition had no consistent effect on AMF structures. However, there were hints to higher AMF abundance with higher diversity. Extraradical hyphae were longer in the diverse compared to the grass sward in 2008, though this was not found in 2009, when plant species differences were more pronounced than in 2008. In the grass sward, the AC root length $(P=0.054)$ and total root length infected with AMF structures $(P=0.002)$ were positively related to plant species number in 2009 . Differences in plant species composition and abundances can lead to changes in the AMF community composition with effects on AMF abundance. Differences in soil density, occurring at grazed sites, which can reduce AMF colonization (Nadian et al., 1998) due to reduced pore size and aeration, did not seem to have affected extraradical hyphal length in soil, AC root length or total root length infected in our study (as determined by correlations of these variables with soil density). Even though some results point to higher AMF efficiency with higher plant species richness, this was not related to higher productivity in the diverse 
sward, supporting the finding of Klironomos et al. (2000) that in the presence of AMF plant species may become redundant with respect to productivity.

According to our second hypothesis, we found N1 and P1 grass and diverse C plots to be similar in biomass production and nutrient utilization for $\mathrm{H} 1$ and $\mathrm{H} 2$ and when accumulated over harvests, respectively. However, other results of our study do not support our underlying hypothesis. We expected complementary effects on nutrient uptake and biomass production to be of higher relevance in the more diverse sward and that low $\mathrm{N}$ or $\mathrm{P}$ fertilisation would balance out the assumed disadvantage of the grass sward. However, productivity was similar between swards or even larger in the grass compared to the diverse sward.

Nutrient uptakes approximately corresponded to the biomass production, except for the $\mathrm{N}$ uptake, which was in both swards significantly larger in the N2 compared to the other treatments at H1. Contrary to findings by Soder and Stout (2003), this was due to the dominating effect of higher $\mathrm{N}$ concentration, as an ANCOVA accounting for the $\mathrm{N}$ concentration as the covariable resulted in no significant treatment effect at $\mathrm{H} 1(P=0.089$; data not shown). This is in accordance with short-term application of 200 or $360 \mathrm{~kg} \mathrm{~N} \mathrm{ha}{ }^{-1}$ (Pan et al., 2010; Pontes et al., 2007), but was not found at a long-term application of $100 \mathrm{~kg}$ $\mathrm{N} \mathrm{ha}^{-1}$ (Hejcman et al., 2010).

Unlike our hypothesis and findings in other studies, the $\mathrm{N}$ or P fertilisation treatments did not affect the N:P ratio in the biomass or the allocation to AMF structures, even though the $\mathrm{P}$

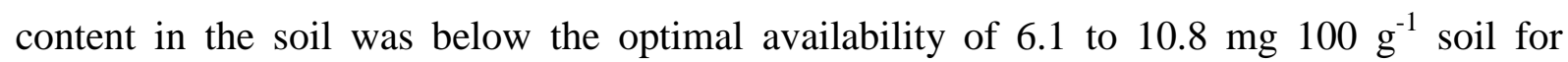
grasslands (Blume et al., 2010) in $47 \%$ of the plots (in July 2008). This missing effect might be due to gaseous or leaching losses of $\mathrm{N}$ or fixation of $\mathrm{P}$ (e.g. in oxides), resulting in nutrient availabilities similar to those before fertilization.

However, we found hints confirming our underlying hypothesis of increased allocation to AMF structures with increasing $\mathrm{N}$ or under $\mathrm{P}$ limiting conditions. The extraradical hyphal length was positively related to the $\mathrm{N}$ concentration in the biomass in the grass $(P=0.031)$ and diverse sward $(P=0.006)$ in 2009 and to the $\mathrm{N}: \mathrm{P}$ ratio in the biomass in the diverse sward in $2008(P=0.051)$ and $2009(P=0.050$; Tab. 4). Increasing $P$ concentration in the plant biomass was related to decreased extraradical hyphal length in the grass sward in 2008 $(P=0.018)$. Interestingly, there were some negative APE values in the grass sward at H1 ($4.0 \pm 21.4$ in the grass vs. $6.1 \pm 9.9 \%$ in the diverse P1) and $\mathrm{H} 3(-11.5 \pm 8.9$ and $-2.9 \pm 4.4$ in the grass and $3.0 \pm 3.1$ and $3.4 \pm 0.9 \%$ in the diverse $\mathrm{P} 1$ and $\mathrm{P} 2$, respectively) compared to smaller negative values in the diverse sward (-1.6 \pm 11.8 and $-1.7 \pm 5.6$ in the diverse vs. $8.2 \pm$ 16.2 and $1.7 \pm 1.4 \%$ in the grass P1 and P2, respectively). Negative APE values indicate 
smaller P uptake in the P fertilised compared to the control plots. This may have been related to both, a stronger decrease in AMF functioning after $\mathrm{P}$ fertilisation in the grass than in the diverse sward and possibly a stronger $\mathrm{P}$ fixation in the former. The AC root length was contrary to our expectation- in both years unrelated to the $\mathrm{N}: \mathrm{P}$ ratio in the biomass. Even though the fertilisation treatment per se did not affect AMF, these relationships between plant nutrient contents and AMF seem to be in accordance with earlier studies: Covacevich et al. (2006) found AMF colonisation to be decreased by superphosphate fertilisation. Johnson et al. (2003a) detected increased AMF structures in $\mathrm{N}$ fertilized soils of sufficient P content, and Blanke et al. (2005) found tissue $\mathrm{N}$ concentration and $\mathrm{N}: \mathrm{P}$ to be negatively related to the AMF colonisation in plants on a $\mathrm{P}$ polluted field.

Our results for AMF functioning and relations with plant nutrient contents were not consistent over harvests (Tab. 4). One reason may be seasonal effects of mycorrhizal colonisation (Johnson et al., 2003b) that we may have missed due to annual sampling. Furthermore, plant species differences in mycorrhization and small-scale spatial variations in plant nutrient availability may have affected our results. Our results of differing extraradical hyphal length in response to nutrient contents may mirror changes in the AMF communities, since these may change under varying nutrient conditions (Santos et al., 2006).

Corresponding to our expectation and in accordance with other studies (Boller and Nösberger, 1994; Høgh-Jensen and Schjoerring, 1997), there was a significant effect of fertilisation on the amount of fixed $\mathrm{N}$ at $\mathrm{H} 1$ with lowest values in the $\mathrm{N} 2$ treatment and highest values in the $\mathrm{C}$ and P2 diverse plots. However, due to the generally relative low yield proportions of legumes $(2,8$ and $1 \%$ at $\mathrm{H} 1, \mathrm{H} 2$ and $\mathrm{H} 3$, respectively) and the fast degradation of urea-N (Høgh-Jensen and Schjoerring, 1997), N fertilisation did not lead to significant decreases in total fixed $\mathrm{N}$ in our study. The mean proportion of fixed $\mathrm{N}$ was -apart from the untreated control- relatively large in the P2 compared to the other treatments. However, this effect was not as high as was to be expected from findings by Reed et al. (2007): at a P application rate of $1 \mathrm{~g} \mathrm{~m}^{-2}$, the proportion of fixed $\mathrm{N}$ was more than doubled, whereas in our study, fixed $\mathrm{N}$ was enhanced by only $11.6 \%$ at the ten-fold $\mathrm{P}$ application in the $\mathrm{P} 2$ treatment.

\section{Conclusion}

Contrary to our first hypothesis, the accumulated nutrient use and productivity were similar between diverse and grass sward; at two harvests, the grass sward was even more productive than the diverse sward. Legumes played a minor role for the $\mathrm{N}$ supply in the diverse sward and AMF showed some positive but inconsistent correlations with plant species diversity. In line with our hypothesis, biomass production and nutrient uptake among N1 and P1 grass and 
the diverse $\mathrm{C}$ were similar when accumulated over harvests. As expected, legumes were mostly absent from $\mathrm{N}$ fertilised treatments. AMF abundance was not affected by $\mathrm{N}$ or $\mathrm{P}$ fertilisation, though it seemed to be enhanced by conditions of limited $\mathrm{P}$ in some cases. To conclude, we suggest that the high nutrient return in both swards related to the former grazing history as well as the relatively high plant species number in the grass sward resulted in the similar productivity and nutrient use in the grass and diverse sward and that complementary species effects in the diverse sward were of minor importance.

\section{Acknowledgements}

We thank Prof. Dr. Matthias Rillig, Institute of Biology, University of Berlin (Germany), for his advice and valuable comments. 


\section{References}

Amarger, N., A. Mariotti, F. Mariotti, J. Durr, C. Bourguignon, and B. Lagacherie. 1979. Estimate of symbiotically fixed nitrogen in field grown soybeans using variations in ${ }^{15} \mathrm{~N}$ natural abundance. Plant and Soil 52:269-280.

Austin, M.P., and B.O. Austin. 1980. Behaviour of experimental plant communities along a nutrient gradient. Journal of Ecology 68:891-918.

Blanke, V., C. Renker, M. Wagner, K. Füllner, M. Held, A.J. Kuhn, and F. Buscot. 2005. Nitrogen supply affects arbuscular mycorrhizal colonization of Artemisia vulgaris in a phosphatepolluted field site. New Phytologist 166:981-992.

Blume, H.-P., G.W. Brümmer, R. Horn, E. Kandeler, I. Kögel-Knabner, R. Kretzschmar, K. Stahr, and B.-M. Wilke. 2010. Schaeffer/Schachtschabel, Lehrbuch der Bodenkunde. 16 ed. Spektrum Akademischer Verlag, Heidelberg.

Boller, B.C., and J. Nösberger. 1994. Differences in nitrogen fixation among field-grown red clover strains at different levels of ${ }^{15} \mathrm{~N}$ fertilization. Euphytica 78:67-174.

Bristow, A.W., D.C. Whitehead, and J.E. Cockburn. 1992. Nitrogenous constituents in the urine of cattle, sheep and goats. Journal of the Science of Food and Agriculture 59:387-394.

Bullock, J.M., R.F. Pywell, M.J.W. Burke, and K.J. Walker. 2001. Restoration of biodiversity enhances agricultural production. Ecology Letters 4:185-189.

Carlsson, G. 2005. Input of nitrogen from $\mathrm{N}_{2}$ fixation to northern grasslands. Dissertation, Swedish University of Agricultural Sciences, Umeå.

Chen, W., W.P. McCaughey, and C.A. Grant. 2004. Pasture type and fertilization effects on $\mathrm{N}_{2}$ fixation, $\mathrm{N}$ budgets and external energy inputs in western Canada. Soil Biology and Biochemistry 36:1205-1212.

Covacevich, F., M.A. Marino, and H.E. Echeverría. 2006. The phosphorus source determines the arbuscular mycorrhizal potential and the native mycorrhizal colonization of tall fescue and wheatgrass. European Journal of Soil Biology 42:127-138.

Development Core Team, R. 2010. R: A language and environment for statistical computing. The R Foundation for Statistical Computing.

Eriksen, J., F.P. Vinther, and K. Søegaard. 2004. Nitrate leaching and $\mathrm{N}_{2}$-fixation in grasslands of different composition, age and management. Journal of Agricultural Science 142:141-151.

Floate, M.J.S. 1970. Decomposition of organic materials from hill soils and pastures: II. Comparative studies on the mineralization of carbon, nitrogen and phosphorus from plant materials and sheep faeces. Soil Biology and Biochemistry 2:173-185.

Fridley, J. 2002. Resource availability dominates and alters the relationship between species diversity and ecosystem productivity in experimental plant communities. Oecologia 132:271-277.

Gollotte, A., D. van Tuinen, and D. Atkinson. 2004. Diversity of arbuscular mycorrhizal fungi colonising roots of the grass species Agrostis capillaris and Lolium perenne in a field experiment. Mycorrhiza 14:111-117.

Hector, A., B. Schmid, C. Beierkuhnlein, M.C. Caldeira, M. Diemer, P.G. Dimitrakopoulos, J.A. Finn, H. Freitas, P.S. Giller, J. Good, R. Harris, P. Högberg, K. Huss-Danell, J. Joshi, A. Jumpponen, C. Körner, P.W. Leadley, M. Loreau, A. Minns, C.P.H. Mulder, G. O'Donovan, S.J. Otway, J.S. Pereira, A. Prinz, D.J. Read, M. Scherer-Lorenzen, E.-D. Schulze, A.-S.D. Siamantziouras, E.M. Spehn, A.C. Terry, A.Y. Troumbis, F.I. Woodward, S. Yachi, and J.H. Lawton. 1999. Plant diversity and productivity experiments in European grasslands. Science 286:1123-1127.

Hejcman, M., J. Szaková, J. Schellberg, and P. Tlustoš. 2010. The Rengen grassland experiment: relationship between soil and biomass chemical properties, amount of elements applied, and their uptake. Plant and Soil 333:163-179.

Helgason, T., J.W. Merryweather, J. Denison, P. Wilson, J.P.W. Young, and A.H. Fitter. 2002. Selectivity and functional diversity in arbuscular mycorrhizas of co-occurring fungi and plants from a temperate deciduous woodland. Journal of Ecology 90:371-384.

Hobbie, S.E. 1992. Effects of plant species on nutrient cycling. Trends in Ecology \& Evolution 7:336339. 
Høgh-Jensen, H., and J.K. Schjoerring. 1994. Measurement of biological dinitrogen fixation in grassland: Comparison of the enriched ${ }^{15} \mathrm{~N}$ dilution and the natural ${ }^{15} \mathrm{~N}$ abundance methods at different nitrogen application rates and defoliation frequencies. Plant and Soil 166:153-163.

Høgh-Jensen, H., and J.K. Schjoerring. 1997. Interactions between white clover and ryegrass under contrasting nitrogen availability: $\mathrm{N}_{2}$ fixation, $\mathrm{N}$ fertilizer recovery, $\mathrm{N}$ transfer and water use efficiency. Plant and Soil 197:187-199.

Hooper, D.U., and P.M. Vitousek. 1997. The effects of plant composition and diversity on ecosystem processes. Science 277:1302-1305.

Hooper, D.U., and P.M. Vitousek. 1998. Effects of plant composition and diversity on nutrient cycling. Ecological Monographs 68:121-149.

Hooper, D.U., and J.S. Dukes. 2004. Overyielding among plant functional groups in a long-term experiment. Ecology Letters 7:95-105.

Jakobsen, I., L.K. Abbott, and A.D. Robson. 1992. External hyphae of vesicular-arbuscular mycorrhizal fungi associated with Trifolium subterraneum L. 1. Spread of hyphae and phosphorus inflow into roots. New Phytologist 120:371-380.

Jakobsen, I., C. Gazey, and L.K. Abbott. 2001. Phosphate transport by communities of arbuscular mycorrhizal fungi in intact soil cores. New Phytologist 149:95-103.

Johnson, D., R.E. Booth, A.S. Whiteley, M.J. Bailey, D.J. Read, J.P. Grime, and J.R. Leake. 2003a. Plant community composition affects the biomass, activity and diversity of microorganisms in limestone grassland soil. European Journal of Soil Science 54:671-678.

Johnson, N.C., D.L. Rowland, L. Corkidi, L.M. Egerton-Warburton, and E.B. Allen. 2003b. Nitrogen enrichment alters mycorrhizal allocation at five mesic to semiarid grasslands. Ecology 84:1895-1908.

Jung, R. 2003. Stickstofffixierleistung von Luzerne (Medicago sativa L.), Rotklee (Trifolium pratense) und Persischem Klee (Trifolium resupinatum L.) in Reinsaat und Gemenge mit Poaceen. Dissertation, Georg-August University, Goettingen.

Kesting, S., N. Wrage, and J. Isselstein. 2009. Herbage mass and nutritive value of herbage of extensively managed temperate grasslands along a gradient of shrub encroachment. Grass and Forage Science 64:246-254.

Klatt, S. 2008. Der Beitrag heimischer Leguminosen zur Stickstoffversorgung artenreicher Wiesen im westlichen Hunsrück (Rheinland-Pfalz). Monography, Trier, Cuvillier Verlag Goettingen.

Klironomos, J.N., J. McCune, M. Hart, and J. Neville. 2000. The influence of arbuscular mycorrhizae on the relationship between plant diversity and productivity. Ecology Letters 3:137-141.

McGonigle, T.P., M.H. Miller, D.G. Evans, G.L. Fairchild, and J.A. Swan. 1990. A new method which gives an objective measure of colonization of roots by vesicular \& arbuscular mycorrhizal fungi. New Phytologist 115:495-501.

Nadian, H., S.E. Smith, A.M. Alston, R.S. Murray, and B.D. Siebert. 1998. Effects of soil compaction on phosphorus uptake and growth of Trifolium subterraneum colonized by four species of vesicular-arbuscular mycorrhizal fungi. New Phytologist 140:155-165.

O'Connor, P.J., S.E. Smith, and F.A. Smith. 2002. Arbuscular mycorrhizas influence plant diversity and community structure in a semiarid herbland. New Phytologist 154:209-218.

Pan, J., B. Widner, D. Ammerman, and R. Drenovsky. 2010. Plant community and tissue chemistry responses to fertilizer and litter nutrient manipulations in a temperate grassland. Plant Ecology 206:139-150.

Pontes, L.S., P. Carrère, D. Andueza, F. Louault, and J.F. Soussana. 2007. Seasonal productivity and nutritive value of temperate grasses found in semi-natural pastures in Europe: responses to cutting frequency and N supply. Grass and Forage Science 62:485-496.

Reed, S.C., T.R. Seastedt, C.M. Mann, K.N. Suding, A.R. Townsend, and K.L. Cherwin. 2007. Phosphorus fertilization stimulates nitrogen fixation and increases inorganic nitrogen concentrations in a restored prairie. Applied Soil Ecology 36:238-242.

Reich, P.B., D. Tilman, S. Naeem, D.S. Ellsworth, J. Knops, J. Craine, D. Wedin, and J. Trost. 2004. Species and functional group diversity independently influence biomass accumulation and its response to $\mathrm{CO}_{2}$ and N. Proceedings of the National Academy of Sciences of the United States of America 101:10101-10106.

Roy, J. 2001. How does biodiversity control primary productivity?, p. 169-186, In S. B. Roy J., Mooney H. A., ed. Terrestrial global productivity. Academic Press,, San Diego, USA. 
Sanderson, M.A., R.H. Skinner, D.J. Barker, G.R. Edwards, B.F. Tracy, and D.A. Wedin. 2004. Plant species diversity and management of temperate forage and grazing land ecosystems. Crop Science 44:1132-1144.

Santos, J.C., R.D. Finlay, and A. Tehler. 2006. Molecular analysis of arbuscular mycorrhizal fungi colonising a semi-natural grassland along a fertilisation gradient. New Phytologist 172:159168.

Serraj, R., T.R. Sinclair, and L.C. Purcell. 1999. Symbiotic $\mathrm{N}_{2}$ fixation response to drought. Journal of Experimental Botany 50:143-155.

Shearer, G., and D.H. Kohl. 1986. $\mathrm{N}_{2}$ fixation in field settings: estimations based on natural ${ }^{15} \mathrm{~N}$ abundance. Australian Journal of Plant Physiology 13:699-756.

Smith, F.A., and S.E. Smith. 1997. Structural diversity in (vesicular)-arbuscular mycorrhizal symbioses. New Phytologist 137:373-388.

Soder, K.J., and W.L. Stout. 2003. Effect of soil type and fertilization level on mineral concentration of pasture: Potential relationships to ruminant performance and health. Journal of Animal Science 81:1603-1610.

Spehn, E.M., M. Scherer-Lorenzen, B. Schmid, A. Hector, M.C. Caldeira, P.G. Dimitrakopoulos, J.A. Finn, A. Jumpponen, G. O'Donnovan, J.S. Pereira, E.-D. Schulze, A.Y. Troumbis, and C. Körner. 2002. The role of legumes as a component of biodiversity in a cross-European study of grassland biomass nitrogen. Oikos 98:205-218.

Tilman, D., J. Knops, D. Wedin, P. Reich, M. Ritchie, and E. Siemann. 1997. The influence of functional diversity and composition on ecosystem processes. Science 277:1300-1302.

van der Heijden, M.G.A., J.N. Klironomos, M. Ursic, P. Moutoglis, R. Streitwolf-Engel, T. Boller, A. Wiemken, and I.R. Sanders. 1998. Mycorrhizal fungal diversity determines plant biodiversity, ecosystem variability and productivity. Nature 396:69-72.

van Ruijven, J., and F. Berendse. 2005. Diversity-productivity relationships: Initial effects, long-term patterns, and underlying mechanisms. Proceedings of the National Academy of Sciences of the United States of America 102:695-700.

Vierheilig, H., A.P. Coughlan, U. Wyss, and Y. Piche. 1998. Ink and vinegar, a simple staining technique for arbuscular-mycorrhizal fungi. Applied Environmental Microbiology 64:50045007.

Voigtländer, G., and N. Voss. 1979. Methoden der Grünlanduntersuchung und -bewertung: Grünland, Feldfutter, Rasen. Ulmer, Stuttgart, p. 55.

Weigelt, A., W.W. Weisser, N. Buchmann, and M. Scherer-Lorenzen. 2009. Biodiversity for multifunctional grasslands: equal productivity in high-diversity low-input and low-diversity high-input systems. Biogeosciences 6:1695-1706. 


\section{General Discussion}

I conducted this study to evaluate the potential of co-grazing cattle and sheep for the facilitation of grassland diversity and to determine if the diversity-functionality relationship found in experimental grassland plots also holds in a semi-natural grassland. I investigated the interaction between sward composition and grazing animals on herbage quality and productivity and the effect of sward type and nutrient input through animal excretion on nutrient use affected by legumes and arbuscular mycorrhizal fungi (AMF).

I now want to discuss my findings concerning the following questions: 1) Is co-grazing by cattle and sheep a potential tool for the facilitation of grassland diversity? 2) Does grassland diversity in agricultural pastures lead to benefits for farmers in terms of productivity and herbage quality? 3) Does sward composition and nutrient input affect nutrient use and the functioning of legumes and AMF?

In my investigation, multivariate analyses of vegetation data revealed signficant effects of grazing cattle on the vegetation composition in the grass and diverse swards. Dicot abundance was facilitated by cattle- and co-grazing in the grass and by cattle- and sheep-grazing in the diverse swards. This was on the one hand attributed to the patchy grazing by cattle, opening gaps for dicot establishment, and on the other hand to worse conditions for selective behaviour by sheep in the grass swards. Sheep- and co-grazing had no significant effect on vegetation composition. With co-grazing, the development of vegetation composition was intermediate between sheep- and cattle-grazed paddocks in both grass and diverse swards. Findings of different selectivity of cattle and sheep in both sward types, as also supposed by Rook et al. (2004), even though not resulting in a better sward use or higher plant diversity so far, point to potential vegetation changes by co-grazing cattle and sheep in the longer term. However, longer-term research is necessary to confirm this.

Concerning the second question, the herbage productivity -as assessed at the paddock-level (Chapter II) and in exclosure plots (Chapter III)- was similar between diverse and grass swards. This is contrary to findings of increased hay yield in recreated species-rich hay meadows (Bullock et al., 2007) and studies showing a relationship of plant species richness or functional group richness with productivity (Tilman et al., 2001; van Ruijven and Berendse, 2005). This suggests that complementary resource use with higher plant species or functional group diversity was of minor importance in our study. Two underlying reasons for that were identified: First, plant species number was likely large enough for complementary species interactions to occur even in our 'low-diversity' grass swards, as the threshold of five plant species for increasing productivity suggested by Roy (2001) was exceeded, and second, 
nutrient availability was probably not limited due to the high previous nutrient return with excreta even in the exclosures.

The herbage quality was affected by sward type and grazer species. Herbage quality was in tendency higher in the diverse compared to the grass swards, related to higher abundances of high digestible forbs and legumes, as found in other studies on agricultural grassland (Hofmann and Isselstein, 2005). Sheep, grazing more selectively than cattle, significantly reduced the post-grazing herbage quality: In the diverse swards, protein contents were more reduced in sheep- compared to cattle-grazed paddocks due to the sheeps' preference for forage high in nitrogen $(\mathrm{N})$ content (Wilson, 1976), resulting in lower legume abundances in sheep-grazed paddocks, as also found by Nolan et al. (2001). In the grass swards, fibre contents increased in sheep-grazed treatments, related to their preferential grazing on highly digestible grass species, whereas vegetative and fibrous plant components were avoided, in line with results by Abaye et al. (1994). In contrast, cattle selected forage of high fibre content, especially in the diverse swards. Therefore co-grazing or successive grazing of cattle and sheep appears to be beneficial for the sward use and may result in higher animal performance, as found by Fraser et al. (2007). Grass and diverse sward provided animals with similar forage mass, but the better quality herbage of diverse swards may be more beneficial for animal performance.

The nutrient use in diverse and grass swards was comparable and contrary to other findings not related to plant diversity or the presence of legumes (Hooper and Vitousek, 1998; Spehn et al., 2000). The contribution of legumes to $\mathrm{N}$ supply was small and only marginally affected by fertilisation. This was due to small legume abundances, possibly caused by relatively high $\mathrm{N}$ availability in the soil, low precipitation rates (Serraj et al., 1999) or the dominance of grasses due to only two cuts per year in the exclosures. With respect to AMF, our results were generally inconsistent for sward types and with time, possibly due to seasonal changes in AMF abundance (Johnson et al., 2003) or small-scale changes in biotic or abiotic factors affecting AMF (Johnson et al., 1997) that were not assessed. Generally, root infection with arbuscules and coils, intraradical AMF structures related to AMF functioning, was -in accordance with other studies (Sanders and Fitter, 1992)- rare and varied little among treatments. We found hints to larger AMF abundance in the diverse compared to the grass swards in 2008, possibly due to the often less extensive root system of dicots compared to grasses, making them more dependent on AMF (Sikes, 2010). Extraradical hyphal length was not affected by fertilisation treatment, but increased under conditions of limited P, i.e. with increasing $\mathrm{N}$ content or $\mathrm{N}: \mathrm{P}$ ratio in the plant biomass. This finding is in accordance with 
other studies (Johnson et al., 2005) and might be related to AMF community changes in response to changed nutrient balances, as found by Jumpponen et al. (2005) after $\mathrm{N}$ fertilisation. AMF notably contribute to plant nutrient acquisition and may decrease nutrient leaching losses (van der Heijden, 2010). I conclude that AMF functioning may change under conditions of nutrient imbalances as occurring through fertilisation.

In this study, I found no confirmation for the productivity-functionality relationship in a seminatural grassland. However, under the conditions of the study, diverse swards proved similarly productive as simpler grass-dominated swards and produced herbage of a better quality. This could have effects on animal performance, especially on the more selective sheep. Diverse swards provide the animals with more possibilities of selective and potentially complementary feeding decisions: sheep preferred forbs and especially legumes, while cattle generally were less selective and seemed to prefer grasses. Therefore, complementary feeding effects of cattle and sheep with corresponding effects on sward use and vegetation development in the longer term seem likely. I suggest that on the one hand co-grazing diverse swards has potential for facilitating diversity, but on the other hand may satisfy the agronomic goal of a better animal performance. Due to grazer species specific effects on vegetation development, a targeted use of mono-grazing of either sheep or cattle may be employed in the future to obtain a particular result of vegetational succession. 


\section{References}

Abaye, A.O., V.G. Allen, and J.P. Fontenot. 1994. Influence of grazing cattle and sheep together and separately on animal performance and forage quality. J. Anim Sci. 72:1013-1022.

Bullock, J.M., R.F. Pywell, and K.J. Walker. 2007. Long-term enhancement of agricultural production by restoration of biodiversity. Journal of Applied Ecology 44:6-12.

Fraser, M.D., D.A. Davies, J.E. Vale, W.M. Hirst, and I.A. Wright. 2007. Effects on animal performance and sward composition of mixed and sequential grazing of permanent pasture by cattle and sheep. Livestock Science 110:251-266.

Hofmann, M., and J. Isselstein. 2005. Species enrichment in an agriculturally improved grassland and its effects on botanical composition, yield and forage quality. Grass and Forage Science 60:136-145.

Hooper, D.U., and P.M. Vitousek. 1998. Effects of plant composition and diversity on nutrient cycling. Ecological Monographs 68:121-149.

Johnson, D., J.R. Leake, and D.J. Read. 2005. Liming and nitrogen fertilization affects phosphatase activities, microbial biomass and mycorrhizal colonisation in upland grassland. Plant and Soil 271:157-164.

Johnson, N.C., J.H. Graham, and F.A. Smith. 1997. Functioning of mycorrhizal associations along the mutualism-parasitism continuum. New Phytologist 135:575-585.

Johnson, N.C., D.L. Rowland, L. Corkidi, L.M. Egerton-Warburton, and E.B. Allen. 2003. Nitrogen enrichment alters mycorrhizal allocation at five mesic to semiarid grasslands. Ecology 84:1895-1908.

Jumpponen, A., J. Trowbridge, K. Mandyam, and L. Johnson. 2005. Nitrogen enrichment causes minimal changes in arbuscular mycorrhizal colonization but shifts community compositionevidence from rDNA data. Biology and Fertility of Soils 41:217-224.

Nolan, T., J. Connolly, and M. Wachendorf. 2001. Mixed grazing and climatic determinants of white clover (Trifolium repens L.) content in a permanent pasture. Annals of Botany 88:713-724.

Rook, A.J., B. Dumont, J. Isselstein, K. Osoro, M.F. WallisDeVries, G. Parente, and J. Mills. 2004. Matching type of livestock to desired biodiversity outcomes in pastures - a review. Biological Conservation 119:137-150.

Roy, J. 2001. How does biodiversity control primary productivity? p. 169-186, In S. B. Roy J., Mooney H. A., ed. Terrestrial global productivity. Academic Press, San Diego, USA.

Sanders, I.R., and A.H. Fitter. 1992. The ecology and functioning of vesicular-arbuscular mycorrhizas in co-existing grassland species. New Phytologist 120:517-524.

Serraj, R., T.R. Sinclair, and L.C. Purcell. 1999. Symbiotic $\mathrm{N}_{2}$ fixation response to drought. Journal of Experimental Botany 50:143-155.

Sikes, B.A. 2010. When do arbuscular mycorrhizal fungi protect plant roots from pathogens? Plant Signaling \& Behavior 5:763-765.

Spehn, E.M., J. Joshi, B. Schmid, M. Diemer, and C. Körner. 2000. Above-ground resource use increases with plant species richness in experimental grassland ecosystems. Functional Ecology 14:326-337.

Spehn, E.M., M. Scherer-Lorenzen, B. Schmid, A. Hector, M.C. Caldeira, P.G. Dimitrakopoulos, J.A. Finn, A. Jumpponen, G. O'Donnovan, J.S. Pereira, E.-D. Schulze, A.Y. Troumbis, and C. Körner. 2002. The role of legumes as a component of biodiversity in a cross-European study of grassland biomass nitrogen. Oikos 98:205-218.

Tilman, D., P.B. Reich, J. Knops, D. Wedin, T. Mielke, and C. Lehman. 2001. Diversity and productivity in a long-term grassland experiment. Science 294:843-845.

van der Heijden, M.G.A. 2010. Mycorrhizal fungi reduce nutrient loss from model grassland ecosystems. Ecology 91:1163-1171.

van Ruijven, J., and F. Berendse. 2005. Diversity-productivity relationships: Initial effects, long-term patterns, and underlying mechanisms. Proceedings of the National Academy of Sciences of the United States of America 102:695-700.

Wilson, A. 1976. Comparison of sheep and cattle grazing on a semiarid grassland. Australian Journal of Agricultural Research 27:155-162. 


\section{Summary}

Plant diversity in grassland ecosystems has recently gained increasing interest, as plant diversity has often been found to be related to improved ecosystem functioning. So far, studies of diversity effects have mainly been performed in experimental grasslands with randomly assembled species mixtures varying in plant species number. However, there is little knowledge on diversity effects on ecosystem functioning in semi-natural and agriculturally used ecosystems. Grazing has been suggested to be a useful management tool for the conservation and recreation of diverse grasslands. The effect of co-grazing animals on vegetation composition has received little attention up to now. In this study, I investigated initial effects of cattle and sheep grazing alone or in combination (co-grazing) on vegetation development, herbage quality and productivity of grassland differing in initial plant diversity. Furthermore, I studied effects of fertilisation with nitrogen $(\mathrm{N})$ and phosphorus $(\mathrm{P})$ in amounts simulating input by excretion of animal urine and dung.

The experiment was established in a semi-natural grassland of the plant-sociological community Lolio-Cynosuretum. This moderately species-rich sward (diverse sward) and its grass-dominated counterpart (grass sward), achieved by application of herbicides, is located in the Solling Uplands (Germany). Both sward types were rotationally grazed from spring to autumn by cattle and sheep grazing alone or together.

Cattle-grazing significantly affected vegetation composition in grass and diverse swards. Sheep- and co-grazing had no effect on vegetation composition. The legume abundance was positively related to cattle-grazing, but was reduced in sheep paddocks. Cattle and sheep seem to have adapted their feeding behaviour to the sward composition; sheep were more selective than cattle in both sward types. Dicot abundance was increased by cattle- and co-grazing in the diverse swards and by cattle- and sheep-grazing in the grass swards. Co-grazing did not result in a complementary sward use or in higher plant diversity.

Herbage productivity was similar between sward types and was unaffected by grazing treatment, plant species number and functional group proportions. The diverse swards produced forage of better quality. Sheep- compared to cattle-grazing significantly decreased post-grazing herbage quality.

The accumulated nutrient uptake by the vegetation over three harvests was similar between sward types. Biomass production affected nutrient uptake. Fertilisation treatment did not affect nutrient uptake, except for an increased $\mathrm{N}$ content in the biomass in the high $\mathrm{N}$ treatment. In the diverse swards, the contribution of legumes to the $\mathrm{N}$ supply of the vegetation was generally small and only marginally affected by fertilisation. The fertilisation treatment 
had no effect on the abundance of AMF structures. There were hints to higher AMF functioning at higher plant species numbers and conditions of limited P.

Our results indicate that vegetation development in grazed grasslands seems to be affected by initial vegetation composition and grazing animal species. Results of experimental grasslands seem difficult to confer to semi-natural grasslands in terms of productivity and nutrient use. 


\section{Zusammenfassung}

Pflanzendiversität in Graslandökosystemen hat in den letzten Jahren zunehmend an Interesse gewonnen aufgrund der häufigen Beobachtung des Zusammenhangs von Pflanzendiversität mit Verbesserungen von Ökosystemfunktionen. Bisher wurden Untersuchungen von Diversitätseffekten hauptsächlich in experimentellem Grasland mit zufällig zusammengestellten Artenmischungen variierender Artenzahl durchgeführt. Das Wissen um Diversitätseffekte auf Ökosystemfunktionen in naturnahen, landwirtschaftlich genutzten Ökosystemen ist gering. Beweidung gilt als geeignete Managementmethode zur Wiederherstellung und zum Erhalt von diversem Grasland. Bisher wurde dem Effekt von Mischbeweidung auf die Vegetationszusammensetzung wenig Beachtung geschenkt. In dieser Studie habe ich anfängliche Effekte von allein oder gemeinsam (Mischbeweidung) grasenden Rindern und Schafen auf die Vegetationsentwicklung, Futterqualität und -produktivität von Grasland mit anfänglich unterschiedlicher Zusammensetzung untersucht. Außerdem habe ich die Effekte von Stickstoff (N) und Phosphor (P) in Mengen, die den Beitrag von Tierurin und -exkrementen simulierten, untersucht.

Das Experiment fand in einem naturnahen Grasland der pflanzensoziologischen Gemeinschaft Lolio-Cynosuretum statt. Diese moderat artenreiche Grasnarbe (diverse Variante) und dessen durch Herbizideinsatz Gras-dominierte Variante (Grasvariante), befinden sich im Solling Mittelgebirge (Deutschland). Beide Grasnarben wurden von Frühling bis Herbst von Rindern, Schafen oder beiden gemeinsam in Rotation beweidet.

Rinderbeweidung hatte einen signifikanten Effekt auf die Vegetationszusammensetzung in der Gras- und diversen Variante. Schaf- und Mischbeweidung hatte keinen Effekt auf die Vegetationszusammensetzung. Das Vorkommen von Leguminosen stand in positivem Zusammenhang mit Rinderbeweidung, war aber in Schafparzellen reduziert. Rinder und Schafe schienen ihr Fressverhalten an die Zusammensetzung der Grasnarbe anzupassen; Schafe fraßen in beiden Grasnarbenvarianten selektiver als Rinder. Das Vorkommen von Kräutern wurde in der diversen Grasnarbe durch Rinder- und Mischbeweidung und in der Grasvariante von Schaf- und Rinderbeweidung gefördert. Mischbeweidung hatte weder eine komplementäre Nutzung des Aufwuchses noch eine höhere Diversität zur Folge.

Die Produktivität des Futters zwischen den Grasnarbenvarianten war ähnlich und unbeeinflusst von der Beweidung, der Pflanzenartenzahl und den Ertragsanteilen der funktionellen Gruppen. Die diverse Grasnarbe produzierte Futter einer höheren Qualität. Schaf- im Vergleich zu Rinderbeweidung hatte eine signifikante Verschlechterung der Futterqualität zur Folge. 
Die akkumulierte Nährstoffaufnahme über drei Ernten war zwischen den Grasnarbenvarianten vergleichbar. Die Biomasseproduktion beeinflusste die Nährstoffaufnahme. Düngung hatte keinen Effekt auf die Nährstoffaufnahmen, mit Ausnahme eines erhöhten N-Gehalts der Biomasse bei hoher N-Düngung. Der Beitrag von Leguminosen zur N-Versorgung in der diversen Grasnarbe war gering und nur marginal durch die Düngungsbehandlung beeinflusst. Düngung hatte keinen Effekt auf die Häufigkeit von Mykorrhizastrukturen. Es gab Hinweise auf höhere Aktivität von Mykorrhiza mit zunehmender Pflanzenartenzahl und zunehmender Limitierung von $\mathrm{P}$.

Unsere Ergebnisse deuten darauf hin, dass die Vegetationsentwicklung von beweidetem Grasland sowohl von der anfänglichen Grasnarbenzusammensetzung als auch der Weidetierspezies abhängt. Ergebnisse experimentellen Graslands scheinen in Hinsicht auf Produktivität und Nährstoffnutzung nicht auf ein naturnahes Grasland übertragbar zu sein. 


\section{Curriculum Vitae}

Melanie Seither

Born 09/05/1981 in Landau (Rhineland-Palatinate, Germany)

Professional Experience:

07/2007 - 08/2011

Scientific Employee

at the Agricultural Faculty,

Georg-August-University of Goettingen,

Workgroup of Grassland Science

$\Rightarrow$ Investigation of vegetation development, forage productivity, forage quality and nutrient use in a grazing animal project

Fields of activity:

- data sampling, statistical analysis and interpretation

- oral and written presentation of experimental results

- supervision of trainees

- assistance in Msc course „grazing management“

- mentoring of Bsc thesis: „Effects of different plant diversity on quantity and quality of forage "

Student assistant (fixed-term contracts) at the University of Bielefeld:

- research project on the nitrogen intake of plants from different sources

- field trip ,Seed plants and cryptogams of the eastern Alps'

- practical course, Exercises on the botanics of seed plants'

\section{Academic Education:}

07/2007-08/2011

$10 / 2000-01 / 2007$

\section{PhD}

Agricultural Faculty

Georg-August-University of Goettingen

Workgroup of Grassland Science (Prof. Dr. Johannes Isselstein)

Title dissertation: "The effect of grassland botanical composition and (co-) grazing cattle and sheep on herbage production and sward nutrient utilisation"

\section{Studies of Biology}

at the University of Bielefeld (Germany)

Focuses: Ecology, Botanics

Subsidiary subject: Psychology

Title diploma thesis: "Comparison of mycorrhizal infection at different successional stages and at two different locations at nutrient poor sandy grassland"

\section{School education:}




\section{Presentations and Publications:}

Seither, M., Petersen, U., Wrage, N., \& Isselstein, J. (2010). Effect of mono- and mixed grazing of cattle and sheep on grassland diversity patterns. Grassland Science in Europe. 15: 752-754.

Effect of mono- and mixed grazing of cattle and sheep on grassland diversity patterns.

EGF Conference 2010, Kiel, Germany. (oral presentation)

Effekt von Düngung und Graslanddiversität auf Produktivität und Futterqualität: Arbeitsgemeinschaft Grünland und Futterbau, AGGF (2009), Kleve, Deutschland. (Poster)

Effects of grassland diversity and fertilisation on mycorrhizal abundance: IMC9, The Biology of Fungi (2010), Edinburgh, Scotland. (Poster) 


\section{Acknowledgements}

First of all I thank Prof. Dr. Johannes Isselstein for his supervision and support and the possibility he gave me to extend my knowledge on grassland science and agriculture.

I thank Prof. Dr. Nicole Wrage for her everlasting encouragement and optimism, helpful critics and comments on the manuscripts as well as the mental support.

I thank Christoph Scherber for his valuable statistical advice and support.

I thank Prof. Dr. Matthias Rillig for his advice and comments concerning the measurement of mycorrhizal structures.

I thank Christiane Wunderow for examining my papers in regard to translation errors.

I thank the many student assistants and trainees, who supported me in practical work in the field and in the laboratory.

Many thanks go to my colleagues at the Institute of Grassland Science for the discussions, conversations, support, encouragement and their friendship.

Not forgotten -even if they don't mind- are my furry friends for their company and the good topic they always were.

I thank Artur for his patience and support in difficult times.

Above all I thank my family for their everlasting support and trust in me. 